\title{
Entrepreneurship in Agriculture
}

\section{- Farmer Typology, Determinants and Values}

\author{
Dissertation \\ to attain the doctoral degree (Dr. sc. agr.) \\ of the Faculty of Agricultural Sciences \\ Georg-August-Universität Göttingen
}

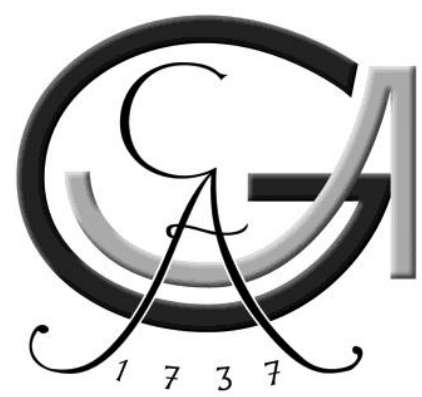

submitted by

\section{Viktoria Graskemper}

born on the $18^{\text {th }}$ July 1991 in Lippstadt 
D7

1. Referee: Prof. Dr. Jan-Henning Feil

2. Referee: Prof. Dr. Xiaohua Yu

3. Referee: Prof. Dr. Stephan von Cramon-Taubadel

Date of oral examination: $28^{\text {th }}$ May 2021 
Ein großer Dank gilt meinem Mann Friedrich sowie meinen Eltern für ihre uneingeschränkte Unterstützung und den seelischen Beistand durch die Höhen und Tiefen meiner Promotionszeit hinweg.

Weiterhin geht ein besonderer Dank an meinen Doktorvater Herrn Prof. Dr. Jan-Henning Feil. Lieber Jan-Henning, danke für die unzähligen Fachdiskussionen, Impulse, Ermutigungen und das stets offene Ohr.

Ein wichtiger Begleiter und Impulsgeber während dieser Zeit war mir Dr. Andreas Quiring. Lieber Andreas, danke für deine Unterstützung; angefangen bei der Ideengenerierung, während der Datenerhebung sowie schlussendlich für die Diskussion und den Praxistransfer der Ergebnisse.

Meinen Prüfern Herrn Prof. Dr. Yu und Herrn Prof. Dr. von Cramon-Taubadel herzlichen Dank! Herrn Prof. Dr. Yu möchte ich außerdem für die gute fachliche Zusammenarbeit während der Promotion danken.

Nicht zuletzt geht ein lieber Dank für die gute Zusammenarbeit und den Austausch ans „Team Feil“!

Danke. 


\section{Contents}

I Introduction ......................................................................................................................... 1

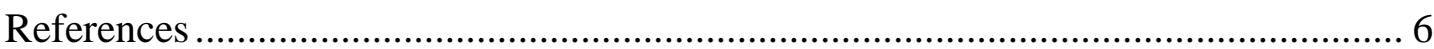

II Farmer typology and implications for policy design - An unsupervised machine learning approach ................................................................................................................ 11

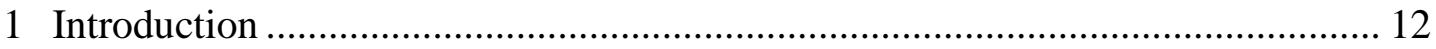

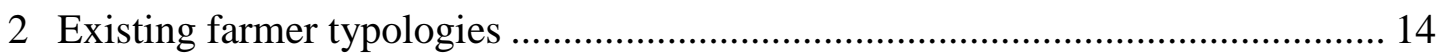

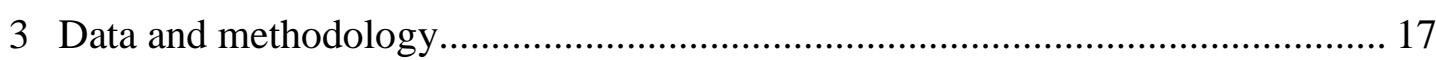

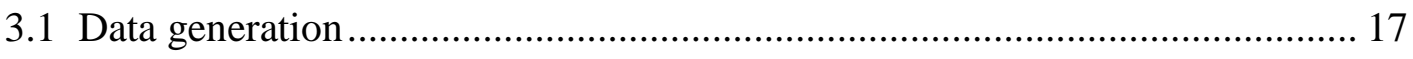

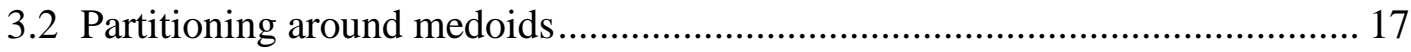

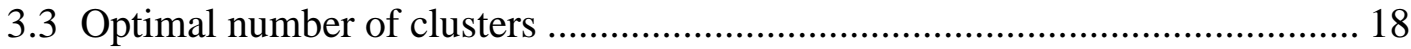

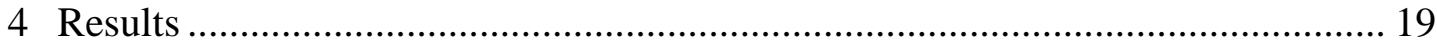

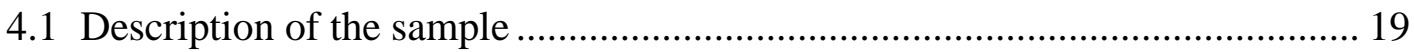

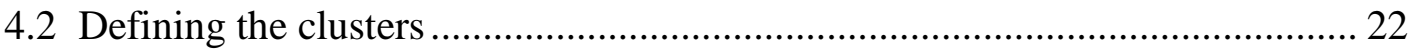

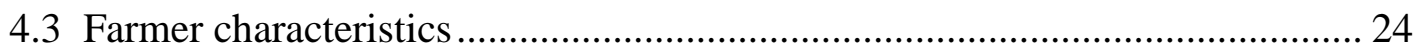

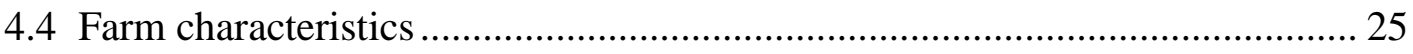

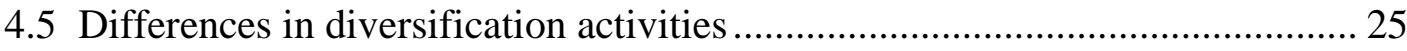

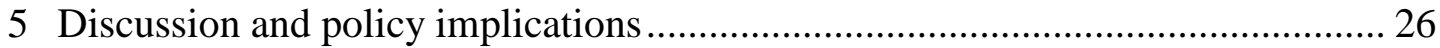

5.1 Clusters as a result of past agricultural policies............................................. 27

5.2 Implications for future agricultural policies .................................................. 28

5.3 Clusters in the context of existing literature ................................................. 31

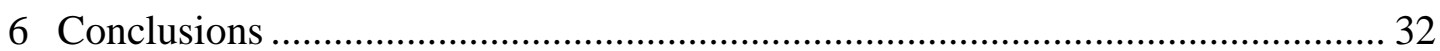

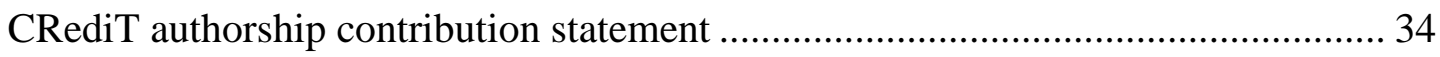

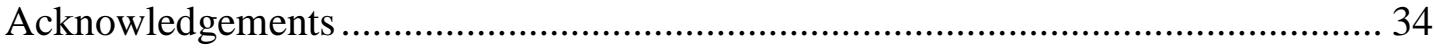

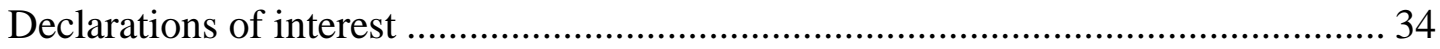

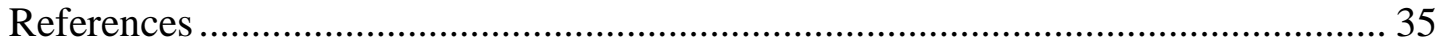

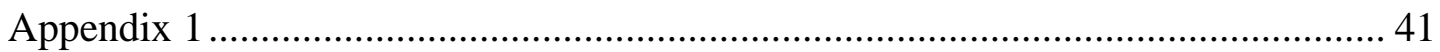

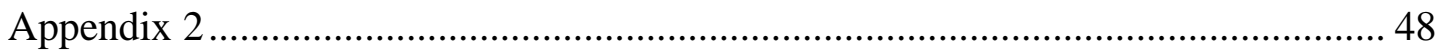

III Analyzing strategic entrepreneurial choices in agriculture - Empirical evidence

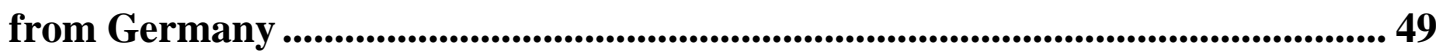

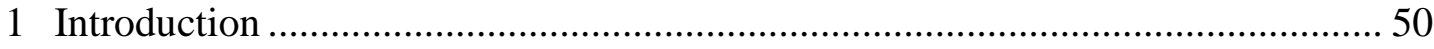

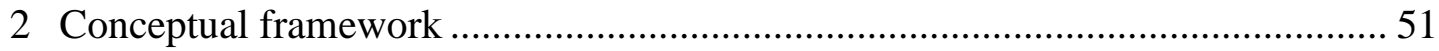

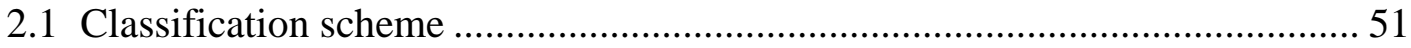


2.2 Possible determinants of strategic entrepreneurial choices in agriculture........ 53

2.2.1 Determinants concerning the farmer ............................................ 53

2.2.2 Determinants concerning the farm ................................................. 55

2.2.3 Determinants concerning the context .......................................... 56

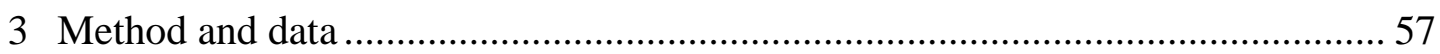

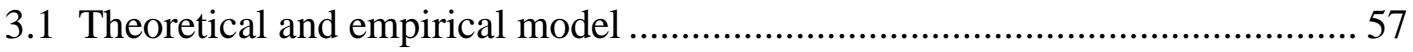

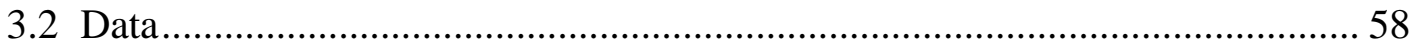

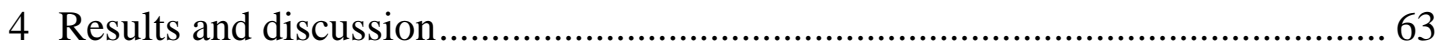

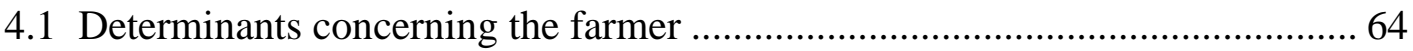

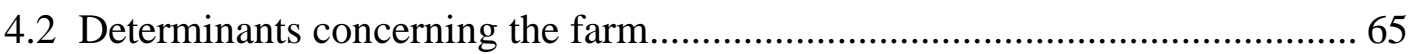

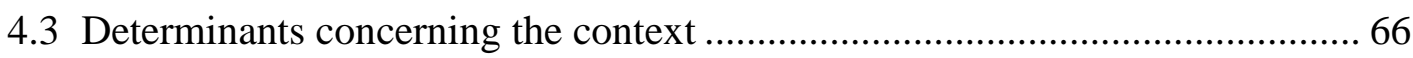

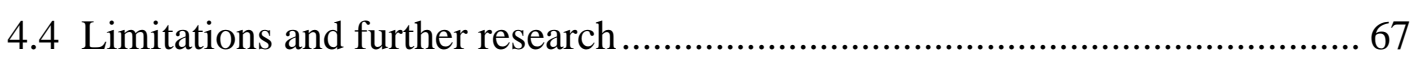

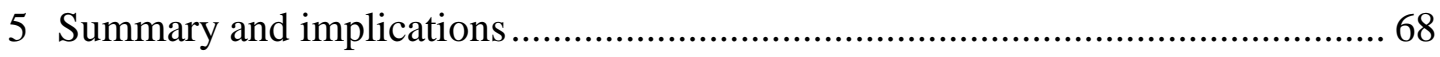

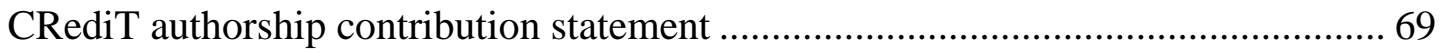

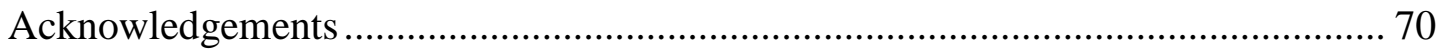

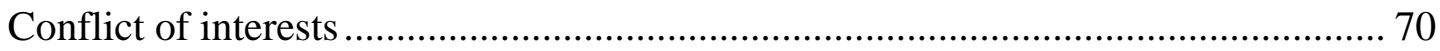

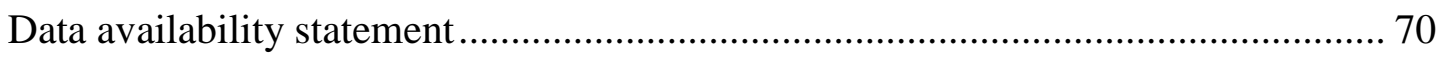

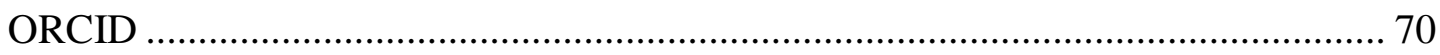

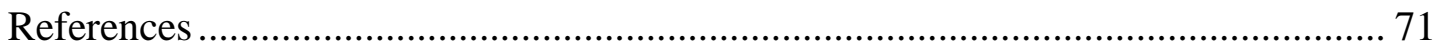

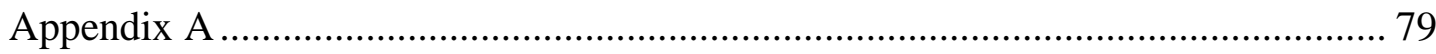

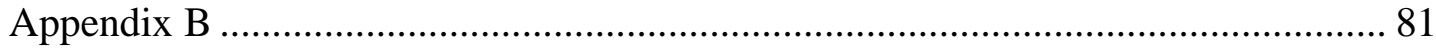

IV Values of Farmers - Evidence from Germany …......................................................... 82

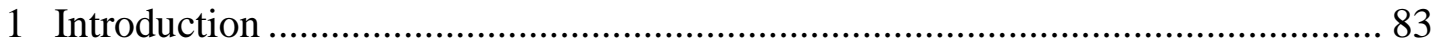

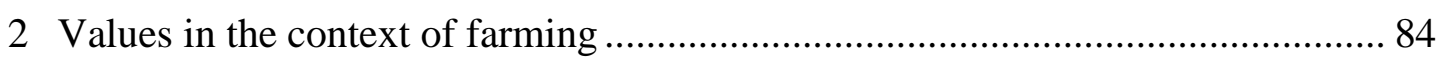

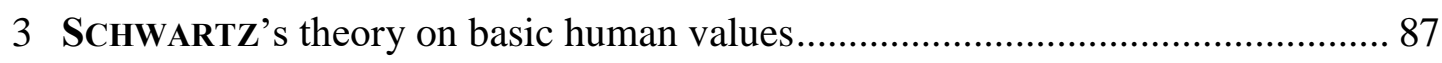

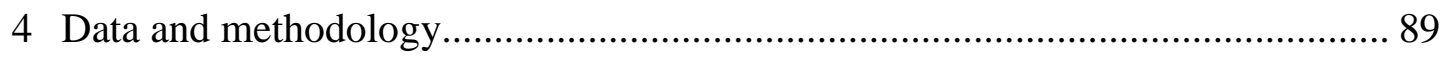

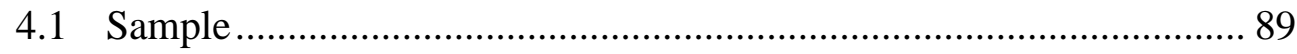

4.2 Statistical analysis of the values....................................................... 92

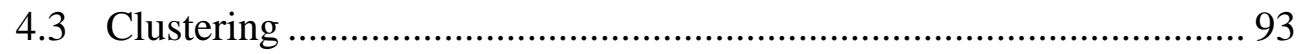

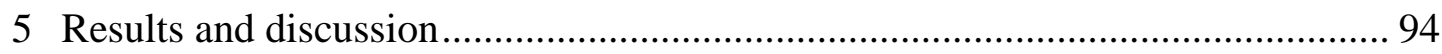

5.1 Visualisation and applicability of the value portrait ......................... 95

5.2 Description of the overall value portrait .......................................... 96

5.3 Different value portraits resulting from the cluster analysis .............. 99

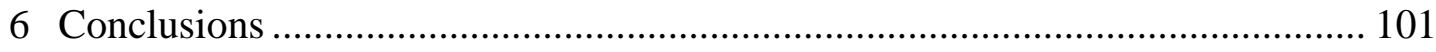


CRediT authorship contribution statement …................................................... 102

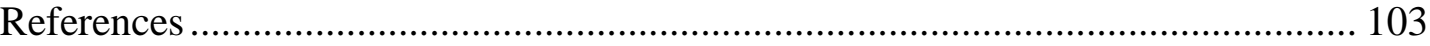

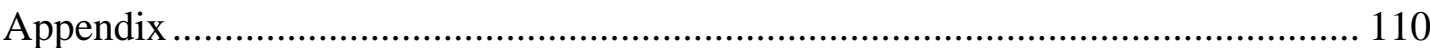

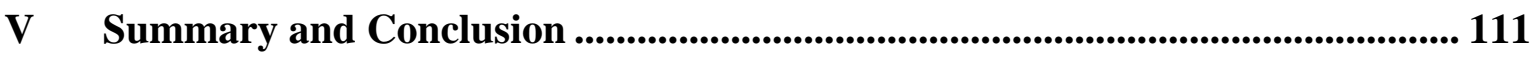

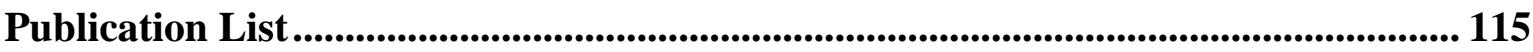




\section{Introduction}

"Entrepreneurship is the mindset and process to create and develop economic activity by blending risk-taking, creativity and / or innovation with sound management, within a new or an existing organisation" (EC, 2003).

This definition derived from the European Commission's Green Paper describes quite precisely what, next to food production, is required nowadays of a European farmer. Unlike any other sector, farming is regarded as key to achieve targets of climate protection, to take care of the cultural landscape and maintain vivid rural areas. This changed requirement profile of farmers is reflected directly within current policy acts such as the European Green Deal with its Farm to Fork Strategy (Grethe et al., 2018; EC, 2019, 2020).

Historically, from the end of the Second World War onwards, the main maxim of agriculture was to increase productivity. This aim is also fixed within the Treaty of Rome along with the promotion of technical progress, ensuring a fair living standard for farmers, market stabilisation, insurance of supplies available and reasonable prices for consumers (EEC, 1957). Over the following decades this led to a massive shift in the focus of farms towards efficiency oriented animal husbandry and crop cultivation. Taking Germany as an example, from 1970 to 2019 the gross value added from agriculture has almost tripled (STATISTA, 2020). In 1949 one farmer fed 10 people while in 2018 the number increased to 134. Simultaneously, the number of people working in agriculture fell from 4,819,000 to 599,000 and the number of farms decreased from 1,646,750 to 266,600 (DBV, 2020). This, in turn, resulted in an alienation of the general public from agriculture and highly specialised agricultural enterprises. Along with the increased wealth, the situation has led to critical questioning of agricultural practices (Zander et al., 2013); the call for more sustainability and animal welfare in agricultural practice is also reflected in a fundamental change of the alignment of agricultural policy (BMEL, 2019a, 2019b; EUCO, 2020).

A major implementation of this change was made in 2000 when a second pillar of rural development policy was introduced next to the first pillar of direct payments within the EU Common Agricultural Policy (CAP). Until then most subsidies were paid according to the amount of cultivated land. By the time, agriculture became more of a cross-cutting discipline including the support of rural development and the provision of ecosystem services as additional major aspects of the CAP implemented through national or regional rural development programmes (Massot, 2020; Nègre, 2020). Even stronger, the upcoming CAP 
reform comprises of green architecture (EUCO, 2020) making a contribution to the European Green Deal which constitutes a strategic roadmap into making the EU's economy sustainable and climate-neutral by 2050 (EC, 2019, 2020). In this context, programmes of the second pillar shall be reinforced once more by transferring $11 \%$ of the present first pillar money (Massot, 2020) as well as by the introduction of mandatory environmental and climate protection programmes, so called eco-schemes reallocating at least $20 \%$ of direct payments. By doing so, farmers shall receive extra money by taking up measures like flower strips for insects or plant protection programmes beyond the scope of basic EU requirements (EU2020, 2020). This change of direction in agricultural policy becomes also evident within national agricultural policy acts such as national strategies for the development of arable farming and animal husbandry as well as various committees dealing with the future of agriculture (BMEL, 2019a, 2019b; LNV, 2019; MAPA, 2020).

To cope with this changed requirement profile, an increasing degree of entrepreneurship is demanded of farmers (Grethe et al., 2018). Despite this fact, the existing literature on this topic still requires further research. A huge body of literature deals with the skills of farm entrepreneurs (e. g. Wolf et al., 2004; Pyysiäinen et al., 2006; Wolf and Schoorlemmer, 2007; Morgan et al., 2010; Seuneke et al., 2013). Furthermore, some studies create clusters describing farmer typologies which are mostly narrowed to selected aspects or study regions. They are often designed to derive implications for rural policy design (e. g. Huynh et al., 2014) or limited towards certain entrepreneurial strategies such as farm diversification often using subjective variables like those obtained by likert scales (e. g. Weltin et al., 2017). Continuing this path, instead of taking an overarching perspective of the entire entrepreneurship process and the full range of strategy choices farmers have, most studies in this field also rather focus on selected aspects, such as motives to diversify the business (e. g. Ilbery, 1991; Nickerson et al., 2001; Alsos et al., 2003; Barbieri and Mahoney, 2009; Northcote and Alonso, 2011; Vik and McElwee, 2011; Hansson et al., 2013). Regarding the topic of entrepreneurship from another perspective, the decision-making behaviour of farmers is something that rational economic theories are incapable of accurately explaining in isolation as the structures of enterprises are very interwoven (Gasson, 1973). Farm management differs from purely commercial enterprises in that a traditional, family-run farm organisation often prevails. Farm Management decisions mostly have direct influence on the daily life, not only business related but also in regards to personal life (Ashby, 1953; Gasson and Errington, 1993). The identification with the changed requirement profile re- 
sulting from the social and political trends and the decisions between the numerous entrepreneurial choices farmers make are determined not only by the hard facts but also by the underlying individual value portrait (Gasson, 1973; Ilbery, 1983). In this context, values are described as a catalyst for entrepreneurship (Hemingway, 2005). However, studies on the underlying value orientation of farmers are rare (Fitz-Koch et al., 2018). Studies dealing with this topic are mostly based on rather small samples with a high average age of the sample (Dobricki, 2011; Baur et al., 2016).

Given this starting point, three research areas arise to be tackled within this cumulative dissertation approaching the topic of entrepreneurship in agriculture from different angles:

1. Which different farmer typologies can be distinguished and how do they differ in personal characteristics and entrepreneurial activities? What implications can be derived for policy design?

2. Which different strategic entrepreneurial choices in agriculture exist in general and what factors determine the decision for a certain strategy?

3. Which value portrait underlies the entrepreneurial activity of farmers? Do typical groups of value portraits exist among the sample and how do they differ among personal characteristics and entrepreneurial activities?

As the second largest agricultural producer in the EU with a share of $13 \%$ of the European agricultural production (DBV, 2018) the contributions exemplarily take a closer look at German farmers.

As a crucial pre-requisite for an effective, target-group oriented design and communication of future agricultural policies the first contribution entitled "Farmer typology and implications for policy design - An unsupervised machine learning approach" addresses the first research questions. Regarding the current process of a fundamental realignment of agricultural policy it becomes evident that this is a rather complex issue and cannot be executed without fundamental understanding of farmers and their needs. This can be inter alia concluded from the vivid debate about the future orientation of agricultural policy and largescale farmer protests in Germany and other European countries against the implementation of new fertiliser ordinances, low prices, or national action programmes aiming at nature conservation and animal welfare (BBC, 2019; Chiarello and Libert, 2019; Schaart, 2019; ARD, 2019; agrarheute, 2021). The protests point out as well that politicians cannot afford to make any more missteps in the future. As farmers fulfil multifaceted tasks and are dy- 
namic business operators (Morris et al., 2017) a multidimensional perspective incorporating many quantitative factors describing not only the farmer, but also their farm and its context is applied. To overcome the issue of a bias of respondents' opinions in the study at hand, a wide range of objective variables is used and to correct for a potential researchers' bias towards specific topics, an unsupervised machine learning approach is applied in contribution one. In addition, a closer look is taken at the farmers' entrepreneurial activities on the basis of a rich data set describing not only basic, but also detailed information about diversification activities. Implications are derived for translating the rather general guidelines of the upcoming CAP reform and the related Farm to Fork Strategy at EU level into concrete policy measures at national and regional level.

Contribution two entitled "Analysing strategic entrepreneurial choices in agriculture Empirical evidence from Germany" is dedicated to the second set of research questions. As a novelty compared to existing studies mostly regarding either conventional strategies such as growth or decline in known areas or more innovative concepts such as diversification strategies, within this study they are considered together to gain a complete picture of the strategic choices farmers have. This is of special relevance as the current developments in agricultural policy and the vivid discussions about the future of agriculture within the society and the sector itself demonstrate that farmers face new requirements. Common strategies of growth and expansion of known production activities do not work for all farmers anymore. This leads to a high heterogeneity in farm business development paths (Morris and Potter, 1995). A basic knowledge of the determinants of different strategic choices of farmers is of particular importance as many policies aim at strengthening family farms and rural areas (Grethe et al., 2018), while expanding structures and withdrawing smaller farms (DBV, 2018). After setting up the classification scheme, a multinomial logit model is applied to analyse the effects of the determinants. This makes it possible to gain a fuller picture of the strategy choice of farmers and to derive conclusions for farmers, the sector and for policy.

To gain a comprehensive picture of farmers' deeper motivation for entrepreneurial activity, the third contribution tackling research questions three "Values of Farmers - Evidence from Germany" uses the internationally recognised Schwartz theory on basic human values to investigate the value portrait of an extensive group of German farmers. Regarding Germany, besides the inclusion of subsamples (Baur et al., 2016), a study analysing exclusively the value portrait of German farmers and drawing conclusions on their entrepreneur- 
ial activity are absent. To investigate the value portrait, the Personal Value Questionnaire is analysed with the help of multidimensional scaling. To analyse if typical groups of value portraits exist among the sample and how these differ among personal characteristics and entrepreneurial activities, a cluster analysis is performed by means of an unsupervised machine learning approach. Differences between farm and farmer characteristics are further worked out to prepare a ground for future debates and policy programmes. 


\section{References}

agrarheute, 2021. Demo: In ganz Deutschland rollen die Traktoren, München. https://www.agrarheute.com/politik/demo-ganz-deutschland-rollen-traktoren-559862.

Alsos, G.A., Ljunggren, E., Toril Pettersen, L., 2003. Farm-based entrepreneurs: what triggers the start-up of new business activities? Journal of Small Business and Enterprise Development 10 (4), 435-443.

ARD (Arbeitsgemeinschaft der öffentlich-rechtlichen Rundfunkanstalten der Bundesrepublik Deutschland), 2019. Protest von Bauern - Tausende Trecker legen Städte lahm. https://www.tagesschau.de/inland/bauern-protest-101.html.

Ashby, A.W., 1953. The Farmer in Business. Journal of proceedings of the Agricultural Economics Society 10 (2), 91-117.

Barbieri, C., Mahoney, E., 2009. Why is diversification an attractive farm adjustment strategy? Insights from Texas farmers and ranchers. Journal of Rural Studies 25 (1), 58-66.

Baur, I., Dobricki, M., Lips, M., 2016. The basic motivational drivers of northern and central European farmers. Journal of Rural Studies 46, 93-101.

BBC (British Broadcasting Corporation), 2019. Farmers lift Dublin blockade after two days of protests. BBC.

BMEL (Bundesanstalt für Landwirtschaft und Ernährung), 2019a. Ackerbaustrategie 2035: Perspektiven für einen produktiven und vielfältigen Pflanzenbau, Berlin.

BMEL (Bundesanstalt für Landwirtschaft und Ernährung), 2019b. Nutztierstrategie: Zukunftsfähige Tierhaltung in Deutschland, Berlin.

Chiarello, T., Libert, L., 2019. French farmers clog highways to protest at "agri-bashing". REUTERS.

DBV (Deutscher Bauernverband), 2018. Situationsbericht 2018/19: Trends und Fakten zur Landwirtschaft, Berlin.

DBV (Deutscher Bauernverband), 2020. Situationsbericht 2020/21: Trends und Fakten zur Landwirtschaft, Berlin.

Dobricki, M., 2011. Basic Human Values in the Swiss Population and in a Sample of Farmers. Swiss Journal of Psychology 70 (3), 119-127. 
EC (European Commission), 2003. Green Paper: Entrepreneurship in Europe COM(2003) 27 final, Brussels. http://ec.europa.eu/invest-inresearch/pdf/download_en/entrepreneurship_europe.pdf.

EC (European Commission), 2019. From farm to fork: The European Green Deal. Publications Office of the European Union, Luxembourg.

EC (European Commission), 2020. Farm to Fork Strategy: For a fair, healthy and environmentally-friendly food system. $\operatorname{COM}(2020) 381$ final, Brussels.

EEC (European Economic Community), 1957. Vertrag zur Gründung der Europäischen Wirtschaftsgemeinschaft. https://eur-lex.europa.eu/legalcontent/DE/TXT/PDF/?uri=CELEX:11957E/TXT\&from=DE (accessed 17 November 2020).

EU2020, 2020. Von Eco-Schemes bis zu nationalen Strategieplänen: Was sich durch die Reform der Gemeinsamen Agrarpolitik der EU ändern soll. https://www.eu2020.de/eu2020-de/aktuelles/artikel/eu-staaten-einigen-sich-auf-reformder-agrarpolitik/2408636 (accessed 17 November 2020).

EUCO (European Council), 2020. Future of the CAP post 2020. https://www.consilium.europa.eu/en/policies/cap-future-2020/ (accessed 17 November 2020).

Fitz-Koch, S., Nordqvist, M., Carter, S., Hunter, E., 2018. Entrepreneurship in the Agricultural Sector: A Literature Review and Future Research Opportunities. Entrepreneurship Theory and Practice 42 (1), 129-166.

Gasson, R., 1973. Goals and Values of Farmers. Journal of Agricultural Economics 24 (3), $521-542$.

Gasson, R.M., Errington, A., 1993. The farm family business (eng). CAB International, Wallingford, $290 \mathrm{pp}$.

Grethe, H., Arens-Azevedo, U., Balmann, A., Biesalski, H.K., Birner, R., Bokelmann, W., Christen, O., Gauly, M., Knierim, U., Latacz-Lohmann, U., Martinez, J., Nieberg, H., Offermann, F., Pischetsrieder, M., Qaim, M., Renner, B., Schmid, J., Spiller, A., Taube, F., Voget-Kleschin, L., Weingarten, P., 2018. Für eine gemeinwohlorientierte Gemeinsame Agrarpolitik der EU nach 2020: Grundsatzfragen und Empfehlungen. (de). Berichte über Landwirtschaft (Sonderheft 225). 
Hansson, H., Ferguson, R., Olofsson, C., Rantamäki-Lahtinen, L., 2013. Farmers' motives for diversifying their farm business - The influence of family. Journal of Rural Studies $32,240-250$.

Hemingway, C.A., 2005. Personal Values as A Catalyst for Corporate Social Entrepreneurship. Journal of Business Ethics 60 (3), 233-249.

Huynh, T.H., Franke, C., Piorr, A., Lange, A., Zasada, I., 2014. Target groups of rural development policies: development of a survey-based farm typology for analysing selfperception statements of farmers (English). Outlook on Agriculture 43 (2), 75-83.

Ilbery, B.W., 1983. Goals and Values of Hop Farmers. Transactions of the Institute of British Geographers 8 (3), 329.

Ilbery, B.W., 1991. Farm Diversification as an Adjustment Strategy on the Urban Fringe of the West Midlands. Journal of Rural Studies 7 (3), 207-218.

LNV (Ministerie van Landbouw, Natuur en Voedselkwaliteit), 2019. Plan of action: New perspective for agriculture, nature and food quality. https://www.government.nl/ministries/ministry-of-agriculture-nature-and-foodquality/documents/policy-notes/2019/11/30/plan-of-action---supporting-transition-tocircular-agriculture.

MAPA (Ministerio de Agricultura, Pesca y Alimentación), 2020. Plan Estratégico PAC post 2020. https://www.mapa.gob.es/es/pac/post-2020/que-es-el-plan-estrategico.aspx.

Massot, A., 2020. Die künftige Gemeinsame Agrarpolitik nach 2020. https://www.europarl.europa.eu/ftu/pdf/de/FTU_3.2.9.pdf.

Morgan, S.L., Marsden, T., Miele, M., Morley, A., 2010. Agricultural multifunctionality and farmers' entrepreneurial skills: A study of Tuscan and Welsh farmers. Journal of Rural Studies 26 (2), 116-129.

Morris, C., Potter, C., 1995. Recruiting the new conservationists: Farmers' adoption of agri-environmental schemes in the U.K. Journal of Rural Studies 11 (1), 51-63.

Morris, W., Henley, A., Dowell, D., 2017. Farm diversification, entrepreneurship and technology adoption: Analysis of upland farmers in Wales. Journal of Rural Studies 53, $132-143$. 
Nègre, F., 2020. Second pillar of the CAP: rural development policy. https://www.europarl.europa.eu/factsheets/en/sheet/110/second-pillar-of-the-cap-ruraldevelopment-policy.

Nickerson, N.P., Black, R.J., McCool, S.F., 2001. Agritourism: Motivations behind Farm/Ranch Business Diversification. Journal of Travel Research 40 (1), 19-26.

Northcote, J., Alonso, A.D., 2011. Factors underlying farm diversification: the case of Western Australia's olive farmers. Agriculture and Human Values 28 (2), 237-246.

Pyysiäinen, J., Anderson, A., McElwee, G., Vesala, K., 2006. Developing the entrepreneurial skills of farmers: some myths explored. International Journal of Entrepreneurial Behavior \& Research 12 (1), 21-39.

Schaart, E., 2019. Angry Dutch farmers swarm The Hague to protest green rules. POLITICO.

Seuneke, P., Lans, T., Wiskerke, J.S.C., 2013. Moving beyond entrepreneurial skills: Key factors driving entrepreneurial learning in multifunctional agriculture. Journal of Rural Studies 32, 208-219.

STATISTA, 2020. Bruttowertschöpfung der Land-, Forstwirtschaft und Fischerei in Deutschland in den Jahren 1970 bis 2019. https://de.statista.com/statistik/daten/studie/76054/umfrage/bruttowertschoepfung-derforst--landwirtschaft-und-fischerei-seit-2002/ (accessed 23 February 2021).

Vik, J., McElwee, G., 2011. Diversification and the Entrepreneurial Motivations of Farmers in Norway. Journal of Small Business Management 49 (3), 390-410.

Weltin, M., Zasada, I., Franke, C., Piorr, A., Raggi, M., Viaggi, D., 2017. Analysing behavioural differences of farm households: An example of income diversification strategies based on European farm survey data. Land Use Policy 62, 172-184.

Wolf, P.D., Schoorlemmer, H. (Eds.), 2007. Exploring the Significance of Entrepreneurship in Agriculture, Frick, Switzerland.

Wolf, P.D., Schoorlemmer, H., Smit, A.B., Lauwere, C.C. de, 2004. Analysis and Development of Entrepreneurship in agriculture. Acta Horticulturae (655), 199-208. 
Zander, K., Isermeyer, F., Bürgelt, D., Christoph-Schulz, I., Salamon, P., Weible, D., 2013. Erwartungen der Gesellschaft an die Landwirtschaft. Thünen-Institut; Stiftung Westfälische Landschaft. 


\title{
II Farmer typology and implications for policy design - An unsuper- vised machine learning approach
}

\author{
Authors: Viktoria Graskemper, Xiaohua Yu, Jan-Henning Feil
}

Published in: Land Use Policy, 103, 105328.

https://doi.org/10.1016/j.landusepol.2021.105328

\begin{abstract}
Within the European Union, there is currently a vivid debate about the European Green Deal with its Farm to Fork Strategy and the related future design of the Common Agricultural Policy post 2020. This paper contributes to this debate by providing a clustering of German farmers analyzing objective data $(\mathrm{N}=812)$ using Partitioning Around Medoids (PAM) as a crucial pre-requisite for an effective design and communication of future agricultural policies. Accordingly, German farmers can be clustered into three different groups. The conventional growers are the oldest group of farmers, showing the highest land growth rate, and are characterized by a focus on traditional and politically subsidized activities. The versatile youngsters are rather young in age and the majority of them have completed some form of higher education. Their business profile is diverse. The third group of family-based farmers has the highest shares of family support within their farming business and consists mostly of dairy farmers. Policy and communication design needs to consider all these different profiles. Especially new and innovative programs could be developed and tested together with the versatile youngsters. Furthermore, aspects ensuring an effective and economically rewarding production of agricultural goods should be taken into account to offer a perspective for the conventional growers and for food security. Moreover, the family-based farmers constitute a promising target group for rural development programs.
\end{abstract}

Keywords: Machine learning; Partitioning Around Medoids; Agricultural policy; European Green Deal; Farm to Fork Strategy; Farmer typology 


\section{Introduction}

Farm structures have been and are changing globally, leading to vivid discussions regarding the design of agricultural policies. With respect to Europe, a harmonization of national agricultural policies and the provision of food security were, amongst others, crucial reasons for the founding of the European Economic Community, a predecessor of the European Union (EU) (EEC, 1957). Nowadays, agriculture still represents the largest block of expenditure within the EU, with a share of $37.4 \%$ of the total budget in 2019 (EC, 2020c). The founding objectives were fixed in 1957 within the Treaty of Rome and are still widely unchanged (Massot, 2020b). These include increasing agricultural productivity by promoting technical progress, ensuring a fair living standard for farmers, market stabilization, insurance of supplies available and reasonable prices for consumers (EEC, 1957).

However, over time the implementation and the design of the EU Common Agricultural Policy (CAP) have undergone many changes. Aside from the basic function of food supply, the support of rural development and the provision of ecosystem services have become additional major aspects of the CAP. Hence, agricultural policy becomes more of a crosscutting discipline (Massot, 2020b). Traditionally, enhancing agricultural production efficiency dominated, and most subsidies were paid according to the amount of the cultivated land. The CAP reform after 2000 started a redistribution of the subsidies, introducing a second pillar of rural development policy to make agricultural and rural development more sustainable (Nègre, 2020).

Subsequently, the upcoming CAP reform post 2020 comprises of green architecture (EU$\mathrm{CO}, 2020)$ and $11 \%$ of the former money from the first pillar of direct payments for farmers shall be transferred to the second pillar of rural development policy (Massot, 2020a). In this respect, a novelty is the introduction of mandatory environmental and climate protection programs, so called eco-schemes. At least $20 \%$ of the direct payments will be reallocated to these schemes and farmers shall receive extra money if they take measures like flower strips for insects or plant protection measures going beyond the scope of basic EU climate and environmental requirements (EU2020, 2020). For the implementation of the EU regulations, member states shall receive greater freedom and flexibility (EUCO, 2020). The new CAP will also make a significant contribution to the European Green Deal which was presented by the European Commission in December 2019. The Green Deal constitutes a strategic roadmap to make EU's economy sustainable and climate-neutral until 2050. One core initiative thereof is the Farm to Fork Strategy which aims at reducing the 
environmental footprint of food systems, ensuring food security and creating a circular economy from farm to fork. Farmers are regarded as key actors within this context and food systems as important drivers of climate change and environmental degradation (EC, 2019; EC, 2020b). Therefore, until 2030 a 50\% reduction of pesticides used in farming as well as stopping excess fertilization by reducing nutrient losses by at least $50 \%$ and fertilizer use by at least $20 \%$ are set on the agenda. Furthermore, the sale of antimicrobials for farmed animals shall be reduced by 50\% and an increase of organic farming methods with the goal of $25 \%$ organic farmland by 2030 shall be achieved (EC, 2020c). By doing so, EU food systems shall become a global standard for sustainability (EC, 2019; EC, 2020b). In October 2020 the EU agricultural ministers agreed on the Farm to Fork Strategy (EU2020, 2020). Now it is up to the member states to develop national plans to meet country-specific needs.

The problem of how to balance policy is a difficult issue. Recent large-scale protests of farmers within EU countries as a response to the implementation of a new fertilizer ordinance (ARD, 2019) is just one example of how differentiated and targeted policy design and implementation is often not or just partly achieved. In addition, critics of various stakeholders come up questioning if the high agricultural budget is spent wisely and sustainably (The Economist, 2020). Especially with regards to these urgent issues to be tackled within the Green Deal and the new CAP period, politicians cannot afford to make any more missteps in the future. For creating accurate, target-group oriented policy measures, a crucial pre-requisite is to understand the structure of farmers in a comprehensive and objective way. To classify farmers and farm structures from only one or few dimensions (e.g. farm size, farmers' age), does not reach far enough, as the conception of the farmer nowadays for instance gives more and more way to entrepreneurial-focused activities. Farmers fulfill multifaceted tasks; next to producing food, they take care for the cultural landscape and are key actors within the rural communities. They are dynamic business operators being constraint not only by weather and land, but also by social and policy expectations (Morris et al., 2017). This is why a multidimensional perspective incorporating many factors describing the farmer, their farm and its context on the basis of hard facts is needed.

Within the literature, clusters describing farmer typologies are often created with the intention to derive implications for rural policy design (e. g. Huynh et al., 2014) or towards entrepreneurial strategies, especially farm diversification often using subjective variables like those obtained by likert scales (e. g. Weltin, 2017). Thus, the underlying data of the vast 
majority of existing studies analyzing farmer typologies is narrowed to selected aspects and furthermore, picking selected regions. As a result, the explanatory power and generalizability of these typologies is rather limited and the clusters cannot provide a comprehensive typology of farmers, which is independent of the respondents' opinions or the researchers' bias towards a specific topic. Hence, their applicability to support policy design and communication is often restricted.

Therefore, the overall aim of our study is to analyze the typologies of farmers based on a wide range of objective variables regarding their personal, farm and context characteristics, which support an effective, target-group-specific design and communication of policies. To underline and concretize the latter, implications will be derived for translating the rather general guidelines of the upcoming CAP reform and the related Farm to Fork strategy at EU level into concrete policy measures at national and regional level. Although the agricultural sector in Germany is one of the biggest subsidy recipients within the EU with more than $€ 6.2$ billion per year (BMEL, 2020b), a comprehensive typology of German farmers detached from any special strategy or policy focus so far is absent in the literature to the best of the authors' knowledge. To fill this research gap, we conduct a cluster analysis on the basis of a comprehensive farmer survey, which comprises of a wide range of quantitative variables and "hard facts" about their farms, their entrepreneurial activities and socio-demographic data of themselves. Moreover, we corrected for a potential researchers' bias towards specific topics by using an unsupervised machine learning approach with Partitioning Around Medoids (PAM) for the clustering of farmers. Compared with the popular k-means clustering method which can only analyze continual variables, PAM takes mixed data into account (Lesmeister, 2015). By doing so, the paper follows the call of the European Commission to engage in contributing to the debate about future food policy design and creates a basis for the development of future agricultural policies (EC, 2020b).

An overview of existing farmer typologies is presented in Section 2. Data and methodology are described in Section 3. The results of the descriptive statistics and the PAM clustering are presented in Section 4 and discussed in Section 5 in relation to policy design. Finally, conclusions are drawn in Section 6.

\section{Existing farmer typologies}

This section provides a brief overview of existing literature on farmer typologies, as summarized in Table 1; first the ones choosing a cluster approach are presented, followed by 
relevant typologies using different methodological approaches. What the presented existing cluster approaches have in common is that they mainly describe basic strategies of agricultural production. However, the unit of investigation differs among the studies; the clusters describe either the farm (Weltin et al., 2017), the farmer (Nickerson et al., 2001; Lauwere, 2005; Morris et al., 2017), a mixture of both (Huynh et al., 2014), or the pursued strategy (Methorst et al., 2017; García-Arias et al., 2015).

Many studies do not consider all, but just a special group of farmers, like dairy farmers (Methorst et al., 2017), small farms (Guarín et al., 2020), or pick different regions instead of regarding a whole country, see Table 1. Furthermore, the use of qualitative variables is quite common, like Lauwere (2005) using likert scales. Lauwere (2005) identifies clusters based on the farmer's strategic orientation. The social farmers and new growers in this context are ascribed to be "real" entrepreneurs, being more successful and having better future prospects because they choose new ways of production, make use of market opportunities and are innovators within the field.

Furthermore, there are a number of cluster approaches dealing with the topic of diversification. In this context, Weltin et al. (2017) investigate differences in the willingness to diversify in the future, with and without market intervention of the CAP. Regarding the area of diversification as well, Nickerson et al. (2001) present three clusters of farm entrepreneurs in Montana, USA. Furthermore, García-Arias et al. (2015) analyze farm diversification strategies by means of seven quantitative variables. Besides this, Morris et al. (2017) intend to characterize agricultural entrepreneurial choices with regards to the willingness to diversify in the CAP context. Sticking to EU policies, Huynh et al. (2014) develop a farm typology of distinct groups affected by objectives of the rural development policies of the EU.

Next to clustering, there are also farmer typologies worth noting created by using other approaches in relation to farm strategies. McElwee (2008) identifies four different types of entrepreneurial farmers focusing on the economic or business aspects of the farm enterprise. McFadden and Gorman (2016) create three distinct categories of farm household profiles related to diversification and innovative capacity. Darnhofer et al. (2005) identify five different types of organic and conventional farmers. Furthermore, in order to draw conclusions for the design of Agri-environmental schemes, farmer typologies are conducted by Nainggolan et al. (2013). Daloğlu et al. (2014) do this for farmers in the American Corn Belt with regards to the adoption of conservation practices. 
Farmer typology and implications for policy design - An unsupervised machine learning approach

Table 1: Overview of existing farmer typologies.

\begin{tabular}{|c|c|c|}
\hline Authors & Identified typologies & Study region \\
\hline \multicolumn{3}{|c|}{ Typologies using cluster approaches } \\
\hline $\begin{array}{l}\text { Nickerson et al. } \\
(2001)\end{array}$ & Multidimensionals; economists; influentials & Montana, USA \\
\hline Lauwere (2005) & $\begin{array}{l}\text { Prudent farmers; social farmers; traditional growers; new } \\
\text { growers }\end{array}$ & Netherlands \\
\hline $\begin{array}{l}\text { Huynh et al. } \\
\text { (2014) }\end{array}$ & $\begin{array}{l}\text { Part-time traditionalists; mixed farming professionals; life- } \\
\text { style farms; livestock specialists; agro-industrialists }\end{array}$ & $\begin{array}{l}\text { Lahn-Dill district, } \\
\text { north-east Branden- } \\
\text { burg, Germany }\end{array}$ \\
\hline $\begin{array}{l}\text { García-Arias et } \\
\text { al. (2015) }\end{array}$ & $\begin{array}{l}\text { High farming activity; medium farming activity; off-farm; } \\
\text { in recession }\end{array}$ & north-western Spain \\
\hline $\begin{array}{l}\text { Methorst et al. } \\
\text { (2017) }\end{array}$ & $\begin{array}{l}\text { Maximizing production; optimizing resources; diversifying } \\
\text { production; ending production }\end{array}$ & Netherlands \\
\hline $\begin{array}{l}\text { Morris et al. } \\
(2017)\end{array}$ & $\begin{array}{l}\text { Resource maximizers; lifestyle farmers; farm focused; } \\
\text { passive farmers }\end{array}$ & Wales, UK \\
\hline $\begin{array}{l}\text { Weltin et al. } \\
(2017)\end{array}$ & $\begin{array}{l}\text { Diversified small farm households; young organic farm } \\
\text { households; less favored areas-adapted mixed farms; tradi- } \\
\text { tional part-time crop farms; small-scale livestock special- } \\
\text { ists; intensive livestock professionals }\end{array}$ & $\begin{array}{l}\text { different European } \\
\text { regions }\end{array}$ \\
\hline $\begin{array}{l}\text { Guarín et al. } \\
(2020)\end{array}$ & $\begin{array}{l}\text { Peasant farms; part-time farms; diversified businesses; } \\
\text { specialized businesses; new enterprises }\end{array}$ & 14 European countries \\
\hline \multicolumn{3}{|c|}{ Typologies using other approaches } \\
\hline $\begin{array}{l}\text { Darnhofer et al. } \\
(2005)\end{array}$ & $\begin{array}{l}\text { The committed conventional; the pragmatic conventional; } \\
\text { the environment-conscious but not organic; the pragmatic } \\
\text { organic; the committed organic }\end{array}$ & Austria \\
\hline $\begin{array}{l}\text { McElwee } \\
(2008)\end{array}$ & $\begin{array}{l}\text { Farmer as farmer; farmer as entrepreneur; farmer as con- } \\
\text { tractor; rural entrepreneur }\end{array}$ & UK \\
\hline $\begin{array}{l}\text { Nainggolan et } \\
\text { al. (2013) }\end{array}$ & $\begin{array}{l}\text { Older, low income landowners; younger tenant farmers; } \\
\text { younger educated specialized landowners; older special- } \\
\text { ized landowners; established diversifiers; younger educat- } \\
\text { ed diversifiers }\end{array}$ & Murcia, Spain \\
\hline $\begin{array}{l}\text { Daloğlu et al. } \\
\text { (2014) }\end{array}$ & $\begin{array}{l}\text { Traditional; supplementary; business-oriented; non- } \\
\text { operators }\end{array}$ & American Corn Belt \\
\hline $\begin{array}{l}\text { McFadden and } \\
\text { Gorman (2016) }\end{array}$ & $\begin{array}{l}\text { Innovative diversifier; non-innovative diversifier; potential } \\
\text { innovative diversifier }\end{array}$ & Ireland \\
\hline
\end{tabular}

Extending the scope of investigation of farmer typologies in Germany to studies regarding rather specific aspects, Venghaus and Acosta (2018) analyzed the energy crop production in Brandenburg and identified six clusters differing in their energy crop production decision. Blanco-Penedo (2019) used data from four European countries, including Germany, to classify the diversity of organic dairy farms using structural characteristics to draw conclusions on the implementation of herd health plans. Kuhn and Schäfer (2018) group farms based on specialization, size, and stocking density in North Rhine-Westphalia. Andersen et al. (2007) extend the EU farm typology as a basis for assessments in a changing policy 
environment taking into account land use and farming intensity, including Germany as a region of investigation.

\section{$3 \quad$ Data and methodology}

In the following, the process of data generation is described first. Afterwards, the methodology consisting of the PAM clustering and the determining of the optimal number of clusters using the Elbow method is introduced.

\subsection{Data generation}

The data consists of a large quantitative online survey conducted among 926 German farmers and farm successors who already work on the farm and are significantly involved in the management and development of the operation. The survey was conducted over four months from November 2018 to February 2019 and requested information about the farmer, the farm and the context (cf. Appendix 1). The distribution of the survey link and the barcode ran through various channels. Different agricultural institutions, such as farmers' and young farmers' associations and rural education centers, promoted it on their homepages and social media channels, via newsletters and e-mail distribution lists. Additionally, regional and national agricultural magazines published the link within articles. Furthermore, farmers were acquired directly during an agricultural fair and flyers were distributed at various farmer events. After data cleansing, 812 data sets were included into the clustering; 62 were led automatically to the end of the survey as they did not fit the target group, and 52 questionnaires were excluded because of big outliers or inconsistencies within the responses. Descriptive statistics of these variables and the sample are presented in Section 4.1.

\subsection{Partitioning around medoids}

Among the clustering methods, one of the most popular ones is k-means clustering which can, however, only analyze continuous quantitative variables. In contrast, PAM can process mixed data, both quantitative and qualitative, including nominal, ordinal, and interval / ratio data (Lesmeister, 2015). PAM tries to minimize the dissimilarities of all observations to the nearest medoid. Hence, the center of a cluster for k-means is not necessarily one of the input data points, but PAM chooses data points as centers and can be used with arbitrary distances. This is another advantage of PAM. Weltin et al. (2017) applied a similar method. The analysis is conducted by using R statistics software. 
The dissimilarity measure is often defined by the Gower Coefficient (Gower, 1971) which compares cases pairwise (e.g. $\mathrm{i}$ and $\mathrm{j}$ ) in order to calculate a dissimilarity between them in PAM,

$\mathrm{S}_{\mathrm{ij}}=\frac{\sum_{\mathrm{m}}\left(\mathrm{W}_{\mathrm{ijm}} * \mathrm{~S}_{\mathrm{ijm}}\right)}{\sum_{\mathrm{m}} \mathrm{W}_{\mathrm{ijm}}}$

where $S_{i j m}$ is the contribution provided by the $m^{\text {th }}$ variable and $\mathrm{W}_{\mathrm{ijm}}=1$ if the $m^{\text {th }}$ variable is valid or else 0 ;

and $S_{i j m}=1-\left(\right.$ absolute value of $\left.\left(\mathrm{x}_{\mathrm{jm}}-\mathrm{x}_{\mathrm{im}}\right)\right) / \mathrm{r}_{\mathrm{m}}$,

where $r_{m}$ is the range of values for the $m^{\text {th }}$ variable.

After we defined the Gower coefficient which measures the dissimilarity of all the observations to the nearest medoid, we used the Ward distance to minimize the dissimilarity ${ }^{1}$ (Lesmeister, 2015). Ward method minimizes the total within-cluster variance;

$\arg \min \sum_{\mathrm{i}=1}^{\mathrm{k}} \sum_{\mathrm{x} \in \mathrm{S}_{\mathrm{i}}}\left\|\mathrm{x}-\mathrm{u}_{\mathrm{i}}\right\|^{2}$

where $u_{i}$ is the mean of points in cluster $S_{i}$, and $k$ is the number of clusters.

\subsection{Optimal number of clusters}

As the number of clusters is open, the selection of an optimal number of clusters is key to the results. There are many selection methods in the literature (Lesmeister, 2015). R program NbClust() provides 23 criteria for selecting the optimal number of clusters. This study mainly used the Elbow method to judge the optimal number of clusters with Equation (3), which is the within-cluster sum of squares. Graphing the percentage of explained variance by the clusters against the number of clusters, the point of decline of the marginal gain of added information reveals the optimal number of clusters (Kassambara, 2017; Madhulatha, 2012). This number is independent from the researchers' opinion of the optimal number of clusters.

The results show that three is the optimal number of clusters, as derived from the output shown in Figure 1 . The left panel shows that the elbow for number of clusters $=3$ has the steepest turnover, which is consistent with the right panel where number of clusters $=3$ has

\footnotetext{
${ }^{1}$ PAM processes the data following the following steps: (1) Randomly select k observations as the initial medoid; (2) Assign each observation to the closest medoid; (3) Swap each medoid and non-medoid observation, computing the dissimilarity cost; (4) Select the configuration that minimizes the total dissimilarity; (5) Repeat steps two through four until there is no change in the medoids.
} 
the highest second-order difference. In addition, within the 23 criteria provided by NbClust(), 16 show that three are the optimal number, dominating all criteria. Following the majority rule, it confirms that three are the optimal number of clusters once again.
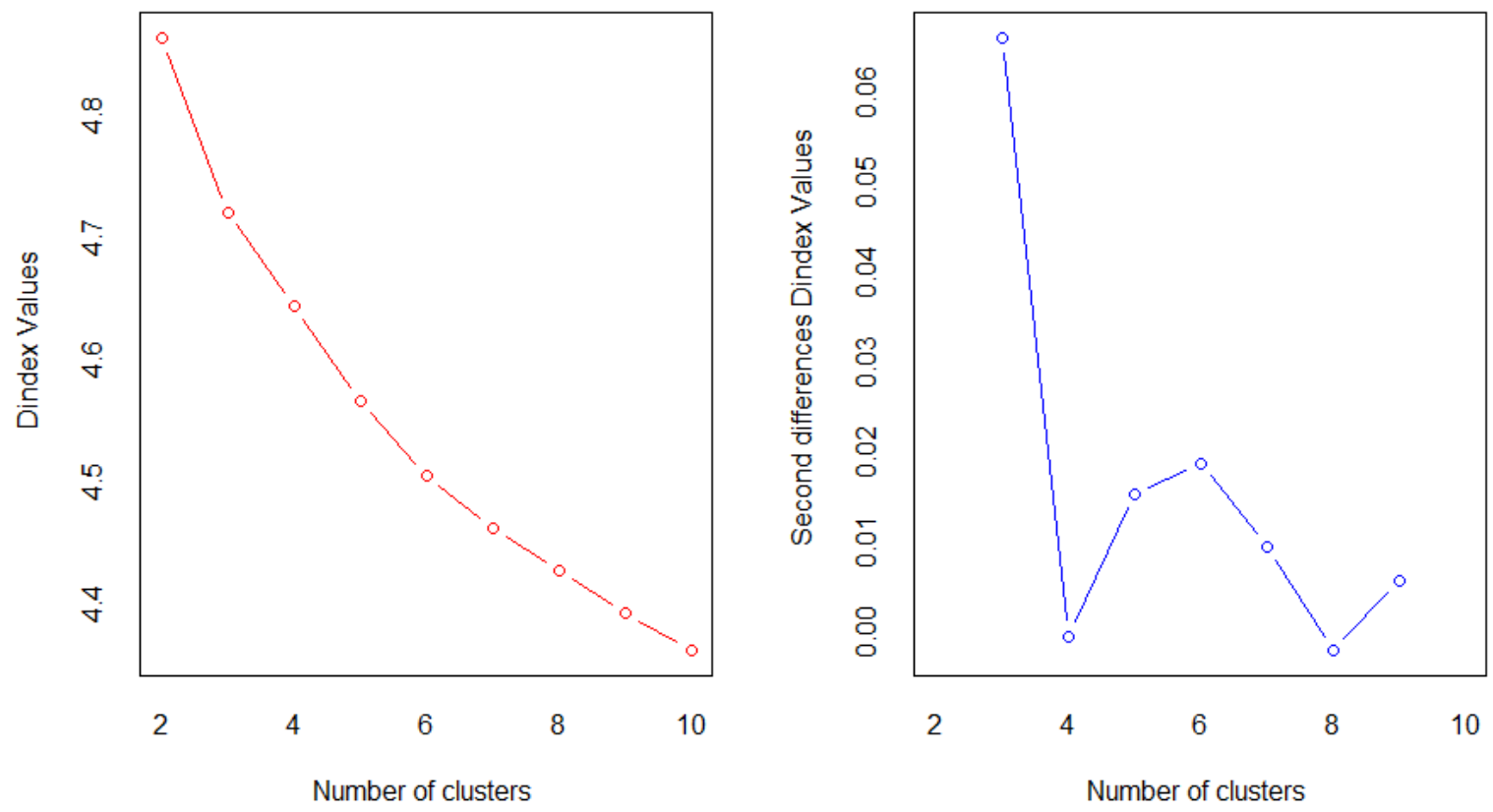

Figure 1: Optimal number of clusters according to the Elbow Method.

As a final step of the analysis, significances of group differences are measured by conducting t-tests using the R command compareGroups().

\section{$4 \quad$ Results}

The results are presented by describing the sample first. Afterwards the clusters are defined followed by a description of the different farmer and farm characteristics. Regarding further differences, a look is taken at the involvement in diversification activities of the different farmer groups.

\subsection{Description of the sample}

In order to obtain the most objective results possible, only hard facts were included in the clustering. Descriptive statistics of the variables included in the clustering are summarized in Table 2. Because of the inclusion of the younger generation farmers, the average age of 38 years is younger than the age within the official census data stating that $34 \%$ of all German farmers are older than 55 years (DBV, 2018).

As most farms in Germany are family-run (IBID.), there is a transition period between two generations of farmers working together on one enterprise. The aim is to get a comprehen- 
sive picture of active farmers. This is why all active farmers were asked to join the survey. As a result, there are some deviations from the census data which, however, do not influence the number of clusters nor the characteristics of the analysis, which would be in the case of a regression analysis.

The share of women is slightly higher than the official German average of $10 \%$ (IBID.) and the share of university degree holders is considerably higher than the census average of $12 \%$ (IBID.) and may be caused by a more open-mindedness of these farmers towards supporting research. Most farmers grew up on a farm because farming is mainly a family business in Germany (IBID.). The average amount of land is high compared to the census data (IBID.) and could be explained by two reasons: first, the relatively high share of fulltime farms (87\%); and second, the relatively high share of farms located in the new federal states with significantly larger farm structures. This is also the reason to include a variable indicating if the farms are located in the West or the former East of Germany. The share of organic farmers is comparable to the census data (IBID.). Regarding the indication of different foci, multiple answers were possible so that in summation more than $100 \%$ are achieved. Most farmers indicate a focus on arable farming what might be due to the fact that some farmers may have stated this in combination with animal husbandry. The share of dairy farmers equals the share of farmers keeping pigs or poultry.

Within the sample, more than half of the farmers have integrated the production of renewable energy into their enterprise. This can mostly be explained by a massive political push in Germany towards the investment in solar, wind and biogas power associated with feedin tariffs secured within the Renewable Energy Sources Act (EEG) since 2000 (UBA, 2019). As this share is this high in Germany and shows a bias on the results (see Appendix 2 ), it is included as a separate variable instead of incorporating it into the variable of structural diversification. 
II Farmer typology and implications for policy design - An unsupervised machine learning approach

Table 2: Descriptive statistics of the variables included in the clustering.

\begin{tabular}{|c|c|c|c|c|c|c|}
\hline Variable & Definition & Scale / measurement & Mean & SD & Min & Max \\
\hline \multicolumn{7}{|l|}{ Farmer } \\
\hline age & Age & number of years & 38.32 & 12.91 & 19 & 74 \\
\hline male & Gender & $1=$ male $; 0=$ female & 0.85 & 0.36 & 0 & 1 \\
\hline degree & $\begin{array}{l}\text { Third-level education; degree from a univer- } \\
\text { sity or university of applied sciences }\end{array}$ & $1=$ yes $; 0=$ no & 0.42 & 0.49 & 0 & 1 \\
\hline edu_agr & Agricultural education & $1=$ yes $; 0=$ no & 0.88 & 0.32 & 0 & 1 \\
\hline partnership & Living in a partnership & $1=$ yes $; 0=$ no & 0.75 & 0.44 & 0 & 1 \\
\hline job & Off-farm job of the farmer & $1=$ yes $; 0=$ no & 0.30 & 0.02 & 0 & 1 \\
\hline childhood & Relation to farming during childhood & $\begin{array}{l}1=\text { grown up on a farm; } \\
2=\text { farm in the family; } \\
3=\text { working on neighbouring } \\
\text { farm; } 4 \text { = no relation to } \\
\text { agriculture }\end{array}$ & 1.24 & 0.67 & 1 & 4 \\
\hline \multicolumn{7}{|l|}{ Farm } \\
\hline size & Farm size, total area under cultivation & number of hectares & 315.91 & 636.38 & 1 & 6200 \\
\hline size_initial & Initial farm size, total area under cultivation & number of hectares & 250.14 & 583.52 & 1 & 6200 \\
\hline fulltime & Farming business in full-time & $1=$ yes $; 0=$ no & 0.87 & 0.34 & 0 & 1 \\
\hline organic & Organic farming & $1=$ yes $; 0=$ no & 0.11 & 0.32 & 0 & 1 \\
\hline foc_arable & Focus on arable farming & $1=$ yes $; 0=$ no & 0.69 & 0.46 & 0 & 1 \\
\hline foc_fordairy & Focus on forage crops and dairy cattle & $1=$ yes $; 0=$ no & 0.31 & 0.46 & 0 & 1 \\
\hline foc_foroth & Focus on other forage crops & $1=$ yes $; 0=$ no & 0.17 & 0.37 & 0 & 1 \\
\hline foc_refine & Focus on refinement; pigs or poultry & $1=$ yes $; 0=$ no & 0.31 & 0.46 & 0 & 1 \\
\hline foc_horti & Focus on horticulture & $1=$ yes $; 0=$ no & 0.02 & 0.15 & 0 & 1 \\
\hline foc_perma & Focus on permanent crops & $1=$ yes $; 0=$ no & 0.06 & 0.24 & 0 & 1 \\
\hline renew_en & Renewable energy (biogas, wind, solar) & $1=$ yes $; 0=$ no & 0.56 & 0.50 & 0 & 1 \\
\hline div_agr & $\begin{array}{l}\text { Engagement in at least one of the following } \\
\text { areas: cultivation of unconventional crops / } \\
\text { keeping of unconventional animal breeds / } \\
\text { forestry / agricultural contraction activities / } \\
\text { wage services }\end{array}$ & $1=$ yes $; 0=$ no & 0.45 & 0.50 & 0 & 1 \\
\hline div_str & $\begin{array}{l}\text { Engagement in at least one of the following } \\
\text { areas: overnight accommodation; leisure } \\
\text { activities; alternative marketing and distribu- } \\
\text { tion channels; processing of agricultural } \\
\text { products; solidary / social / educational } \\
\text { activities; letting of farm buildings for non- } \\
\text { agr. purposes; letting of real estate for resi- } \\
\text { dential purposes; letting of land for non- } \\
\text { agricultural purposes }\end{array}$ & $1=$ yes $; 0=$ no & 0.45 & 0.50 & 0 & \\
\hline soil & $\begin{array}{l}\text { Average soil quality on the agricultural main } \\
\text { site according to the German system of } \\
\text { "Ackerzahl" }\end{array}$ & points $1-100$ & 47.17 & 17.91 & 10 & 100 \\
\hline rain & $\begin{array}{l}\text { Average rainfall on the agricultural main site } \\
\text { in } \mathrm{mm} / \text { year }\end{array}$ & number $\mathrm{mm} /$ year & 702.37 & 184.21 & 250 & 1500 \\
\hline west & $\begin{array}{l}\text { Location of agricultural sites in the old } \\
\text { German states }\end{array}$ & $1=$ yes $; 0=$ no & 0.86 & 0.35 & 0 & 1 \\
\hline central & $\begin{array}{l}\text { Location of the agricultural main site near a } \\
\text { metropolitan area or tourist / recreation } \\
\text { region }\end{array}$ & $1=$ yes $; 0=$ no & 0.11 & 0.31 & 0 & 1 \\
\hline \multicolumn{7}{|l|}{ Context } \\
\hline wf_family & Number of family workers in the business & number of family workers & 1.88 & 1.11 & 0 & 6 \\
\hline wf_spouse & $\begin{array}{l}\text { Spouse works / assists on the farm / in the } \\
\text { business }\end{array}$ & $1=$ yes $; 0=$ no & 0.35 & 0.48 & 0 & 1 \\
\hline coop & Cooperation with other farmers & $1=$ yes $; 0=$ no & 0.77 & 0.42 & 0 & \\
\hline
\end{tabular}


In terms of diversification, the definition of Ilbery (1991) is used, which differentiates between agricultural and structural diversification, adjusted to the present situation. Agricultural diversification includes the cultivation of unconventional crops, the keeping of unconventional animal breeds, and all activities in the area of forestry as well as agricultural contraction / wage services. Structural diversification is composed of overnight accommodation, leisure activities, alternative marketing and distribution channels, processing of agricultural products, solidary / social / educational activities, and the leasing of land and buildings. These are mainly on-farm diversification activities referring to Weltin et al. (2017). Off-farm diversification is represented by the off-farm job of the farmer. What is striking is that the shares of these different diversification types are equal and rather high compared to the census stating that one-third of German farmers pursue diversification activities, including renewable energy production.

Regarding the context, family support within the business is taken into consideration, especially if the spouse works within the farm business. Furthermore, most farmers within the survey cooperate with others.

\subsection{Defining the clusters}

Based on the PAM, the three identified groups are illustrated in Figure 2 and presented in Table 3 and can be characterized as follows:

1. Conventional growers. Represent $28 \%$ of the sample. Farmers are comparable older in age, and focus largely on arable farming or refinement. They are often involved in the production of renewable energy, showing the highest land growth rate of $40 \%$ within their working time;

2. Versatile youngsters. Representing $46 \%$ of the sample. Members of the group are comparable young in age, well-educated, and have large farms mainly focusing on arable farming. Of the versatile youngsters, far more than half of them pursue diversification activities, and have the highest share among the groups. Furthermore, they have the highest share of farmers residing in a part of one of the new federal states among all groups;

3. Family-based farmers. Accounting for $26 \%$ of the sample, the majority are dairy farmers. Most are in a partnership, having the highest shares of family support within the business, and farm on rather small farms, compared to the other groups, with comparable high amounts of rain and less good soil qualities. 
II Farmer typology and implications for policy design - An unsupervised machine learning approach

Table 3: PAM results: characteristics of different farmer groups.

\begin{tabular}{lrrrr}
\hline & $\begin{array}{r}\text { Conventional } \\
\text { growers }\end{array}$ & $\begin{array}{r}\text { Versatile } \\
\text { youngsters }\end{array}$ & $\begin{array}{r}\text { Family-based } \\
\text { farmers }\end{array}$ & $\begin{array}{r}\text { Overall } \\
\text { significance }\end{array}$ \\
\hline Farmer & $\mathrm{N}=224$ & $\mathrm{~N}=375$ & $\mathrm{~N}=213$ & \\
\hline age & & & & \\
male & $42.5(13.9)$ & $35.1(11.3)$ & $39.6(13.0)$ & $<0.001$ \\
degree & $0.88(0.32)$ & $0.84(0.37)$ & $0.82(0.39)$ & 0.138 \\
edu_agr & $0.22(0.41)$ & $0.68(0.47)$ & $0.17(0.38)$ & $<0.001$ \\
partnership & $0.91(0.29)$ & $0.89(0.31)$ & $0.84(0.37)$ & 0.071 \\
job & $0.72(0.45)$ & $0.71(0.46)$ & $0.84(0.37)$ & 0.001 \\
childhood & $0.30(0.46)$ & $0.30(0.46)$ & $0.31(0.46)$ & 0.995 \\
\hline Farm & $1.22(0.66)$ & $1.27(0.69)$ & $1.22(0.63)$ & 0.54 \\
\hline size & & & & \\
size_initial & $272(550)$ & $429(780)$ & $163(330)$ & $<0.001$ \\
fulltime & $194(526)$ & $356(698)$ & $123(334)$ & $<0.001$ \\
organic & $0.89(0.32)$ & $0.87(0.34)$ & $0.85(0.36)$ & 0.488 \\
foc_arable & $0.08(0.27)$ & $0.12(0.33)$ & $0.14(0.34)$ & 0.103 \\
foc_fordairy & $0.79(0.41)$ & $0.86(0.35)$ & $0.30(0.46)$ & $<0.001$ \\
foc_foroth & $0.12(0.32)$ & $0.18(0.39)$ & $0.74(0.44)$ & $<0.001$ \\
foc_refine & $0.13(0.34)$ & $0.18(0.38)$ & $0.18(0.38)$ & 0.338 \\
foc_horti & $0.74(0.44)$ & $0.20(0.40)$ & $0.06(0.24)$ & $<0.001$ \\
foc_perma & $0.01(0.12)$ & $0.02(0.15)$ & $0.03(0.17)$ & 0.548 \\
renew_en & $0.04(0.21)$ & $0.07(0.26)$ & $0.07(0.26)$ & 0.379 \\
div_agr & $0.68(0.47)$ & $0.59(0.49)$ & $0.38(0.49)$ & $<0.001$ \\
div_str & $0.23(0.42)$ & $0.67(0.47)$ & $0.30(0.46)$ & $<0.001$ \\
soil & $0.24(0.43)$ & $0.67(0.47)$ & $0.31(0.46)$ & $<0.001$ \\
rain & $47.2(16.8)$ & $48.9(18.8)$ & $44.2(17.1)$ & 0.009 \\
west & $700(129)$ & $679(178)$ & $746(231)$ & $<0.001$ \\
central & $0.89(0.31)$ & $0.80(0.40)$ & $0.92(0.27)$ & $<0.001$ \\
\hline Context & $0.07(0.25)$ & $0.14(0.35)$ & $0.08(0.28)$ & 0.006 \\
\hline wf_family & $1.72(0.96)$ & $1.82(1.20)$ & $2.16(1.05)$ & $<0.001$ \\
wf_spouse & $0.33(0.47)$ & $0.22(0.42)$ & $0.58(0.49)$ & $<0.001$ \\
coop & $0.81(0.39)$ & $0.78(0.41)$ & $0.72(0.45)$ & 0.088 \\
\hline Not Mean & & & & \\
\hline
\end{tabular}

Note: Means are presented with standard derivations in brackets, variables shaded gray differ significantly $(\mathrm{p}<0.05)$. 


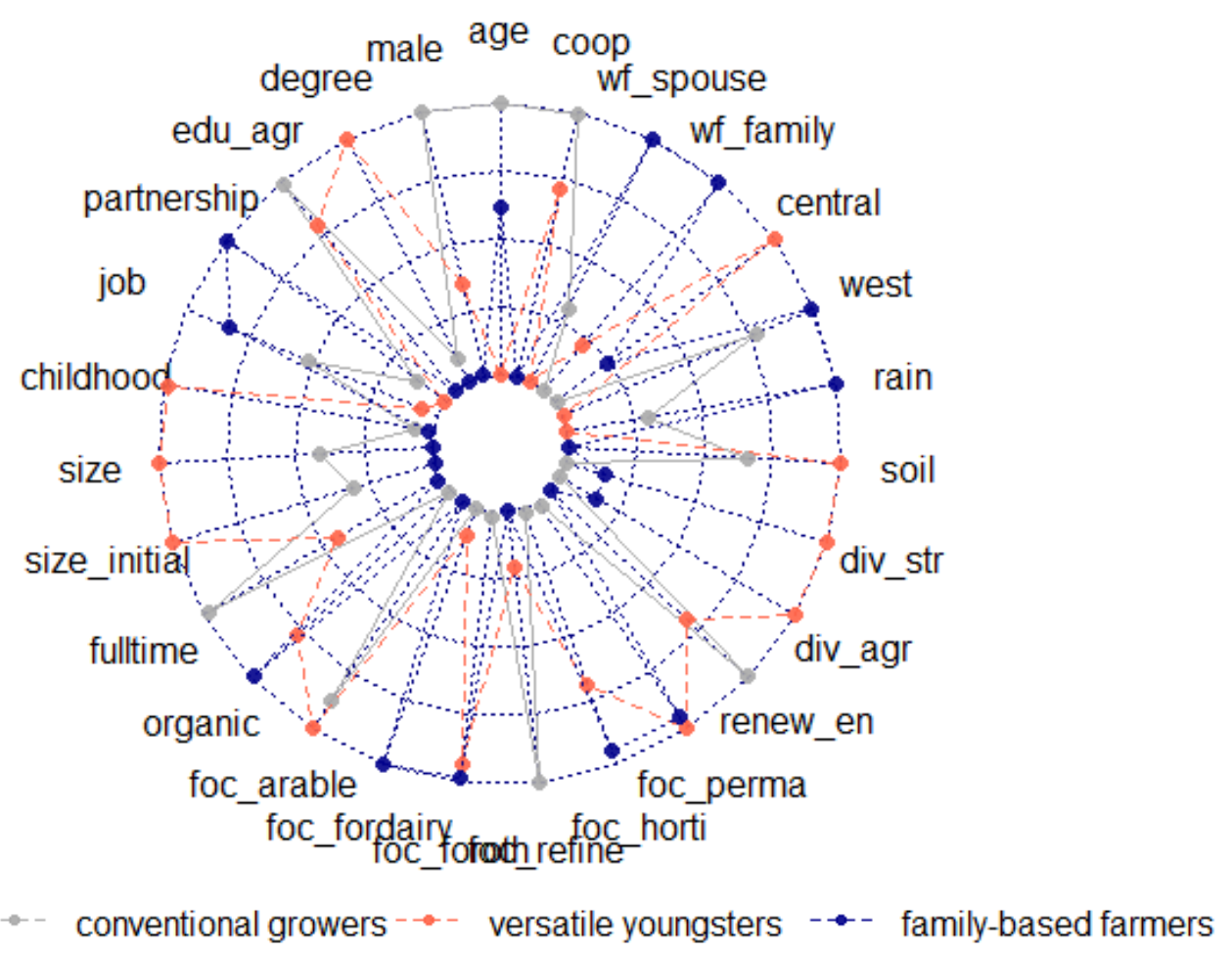

Figure 2: PAM results: characteristics of different farmer groups.

Note: relative distribution of the expression of the variables, inner circle: low expression, outer circle: high expression

\subsection{Farmer characteristics}

Farmers differ significantly in their age and education level in terms of a third-level degree and marital status. The versatile youngsters are the youngest farmers within the sample. The conventional growers are the oldest but close to the family-based farmers. Also, in terms of a third-level degree, the versatile youngsters have by far the highest share of degree-holders. The shares of the other groups are far beyond the one of the versatile youngsters but are close together, while the family-based farmers have the lowest share of degree-holders. At the same time, most of the family-based farmers declared having a spouse, who is in more than half of the cases involved in the business. The number of family workers within the business is also highest for this cluster. The shares of a firm relationship among the other clusters are similar, but, compared to the family-based farmers, the spouse works less often within the business. Throughout all three groups, most farmers have grown up on a farm and one-third is employed in some kind of off-farm work. Nearly all farmers have received an agriculture-related vocational training. 


\subsection{Farm characteristics}

Among the farm characteristics, the groups differ in many ways. The family-based farmers have the least amount of land at their disposal with comparable lowest soil quality and high amounts of rain showing a land growth rate of one third during their working time on the farm which means rank two among the groups. The largest share of the family-based farmers pursues dairy cattle, followed by arable farming with a considerably lower share. The conventional growers dispose over the second highest amount of land, having increased it by $40 \%$ which accounts for the highest land growth rate among the clusters, have better soil quality and less rainfall. They focus mainly on arable farming or on refinement. The versatile youngsters have the largest amount of land at their disposal with the lowest land growth rate of $21 \%$, the best soil quality and the least amount of rainfall compared to the other groups. Their focus is mostly on arable farming. While around $90 \%$ of the farmers within the other clusters are from the West, the share of the versatile youngsters is a bit lower; still they are the ones with the highest share of farmers having a central location. The group which is the most involved in renewable energy production is the one of the conventional growers, followed by the versatile youngsters and, lastly, the family-based farmers.

\subsection{Differences in diversification activities}

Taking a closer look at the involvement in agricultural and structural diversification, the versatile youngsters are the ones showing the highest share of diversification activities. The percentages of agricultural and structural diversification are nearly equal within the groups. Table 4 gives a further insight into which kinds of diversification activities the groups are mainly involved in.

In the field of agricultural diversification, it is striking that agricultural contraction activities and wage services are the most pursued ones; nearly half of the versatile youngsters pursue these activities. Forestry is the second popular agricultural diversification activity pursued especially by the versatile youngsters and family-based farmers followed by some of the versatile youngsters cultivating unconventional crops. Regarding structural diversification, letting of real estate for residential purposes takes a large share followed by alternative marketing and distribution channels. This is especially often pursued by the versatile youngsters. Sticking to this cluster, this is followed by processing of agricultural products, overnight accommodation and leisure activities. 
Table 4: Diversification activities of the different groups (in \%).

\begin{tabular}{|c|c|c|c|c|c|}
\hline & $\begin{array}{r}\text { Conventional } \\
\text { growers }\end{array}$ & $\begin{array}{r}\text { Versatile } \\
\text { youngsters }\end{array}$ & $\begin{array}{r}\text { Family-based } \\
\text { farmers }\end{array}$ & $\begin{array}{l}\text { Overall } \\
\text { sign. }\end{array}$ & ALL \\
\hline \multicolumn{6}{|l|}{ Agricultural diversification } \\
\hline $\begin{array}{l}\text { cultivation of unconventional } \\
\text { crops }\end{array}$ & $0.03(0.16)$ & $0.11(0.31)$ & $0.01(0.12)$ & $<0.001$ & $0.06(0.24)$ \\
\hline $\begin{array}{l}\text { keeping of unconventional } \\
\text { animal breeds }\end{array}$ & $0.03(0.16)$ & $0.06(0.24)$ & $0.04(0.19)$ & 0.118 & $0.05(0.21)$ \\
\hline forestry & $0.06(0.23)$ & $0.22(0.42)$ & $0.15(0.36)$ & $<0.001$ & $0.16(0.37)$ \\
\hline $\begin{array}{l}\text { agricultural contraction activi- } \\
\text { ties, wage services }\end{array}$ & $0.16(0.37)$ & $0.45(0.50)$ & $0.18(0.39)$ & $<0.001$ & $0.30(0.46)$ \\
\hline \multicolumn{6}{|l|}{ Structural diversification } \\
\hline overnight accommodation & $0.02(0.15)$ & $0.09(0.29)$ & $0.04(0.20)$ & 0.001 & $0.06(0.24)$ \\
\hline leisure activities & $0.04(0.19)$ & $0.08(0.27)$ & $0.03(0.18)$ & 0.018 & $0.06(0.23)$ \\
\hline $\begin{array}{l}\text { alternative marketing and } \\
\text { distribution channels }\end{array}$ & $0.11(0.31)$ & $0.27(0.45)$ & $0.12(0.33)$ & $<0.001$ & $0.19(0.39)$ \\
\hline $\begin{array}{l}\text { processing of agricultural } \\
\text { products }\end{array}$ & $0.05(0.22)$ & $0.11(0.32)$ & $0.06(0.23)$ & 0.005 & $0.08(0.27)$ \\
\hline $\begin{array}{l}\text { solidary / social / educational } \\
\text { activities }\end{array}$ & $0.02(0.13)$ & $0.03(0.18)$ & $0.01(0.12)$ & 0.225 & $0.02(0.16)$ \\
\hline $\begin{array}{l}\text { letting of farm buildings for } \\
\text { non-agr. purposes }\end{array}$ & $0.04(0.21)$ & $0.21(0.40)$ & $0.04(0.20)$ & $<0.001$ & $0.12(0.32)$ \\
\hline $\begin{array}{l}\text { letting of real estate for resi- } \\
\text { dential purposes }\end{array}$ & $0.10(0.30)$ & $0.35(0.48)$ & $0.11(0.32)$ & $<0.001$ & $0.22(0.42)$ \\
\hline $\begin{array}{l}\text { letting of land for non- } \\
\text { agricultural purposes }\end{array}$ & $0.00(0.07)$ & $0.08(0.27)$ & $0.02(0.15)$ & $<0.001$ & $0.04(0.21)$ \\
\hline
\end{tabular}

Note: Means are presented with standard derivations in brackets, variables shaded gray differ significantly $(\mathrm{p}<0.05)$.

\section{Discussion and policy implications}

The identified farmer groups are created using PAM on the basis of different characteristics of the farmers, their farms and their context. Previous findings indicate that the organization of the farm is often a result of the farmer's personality because of a deep personal involvement of the farmer and their operation and identification with agriculture (Vesala and Vesala, 2010; Vik and McElwee, 2011). The self-identity of a farmer in turn has an influence on the participation in policy programs as well (Cullen et al., 2020). Additionally, the groups are shaped by the political context. The results indicate that German farmers can be clustered into three groups: conventional growers, versatile youngsters and familybased farmers, showing different characteristics. Considering this, the results provide a basis for the design of targeted future policy measures, which are discussed further in the following. 


\subsection{Clusters as a result of past agricultural policies}

From the perspective of past agricultural policies in Germany and the EU, the conventional growers appear to be the ones that are especially shaped by decades of enhancement of agricultural productivity (Massot, 2020b). Most of them have a focus on arable farming $(79 \%)$ or refinement $(74 \%)$ representing typical strands of agricultural production (DBV, 2019). They are the group with the highest increase in agricultural land during their working time on the farm (40\%), which indicates a longing for growth. Additionally, the highest share of the production of renewable energy (68\%) applies to the conventional growers allowing the conclusion that they are sensible to political incentives (UBA, 2019). From their choice of either well-established models of production or subsidized activities, it might be concluded that the conventional growers put an emphasis on secured returns. By pursuing efficient models of production, they account for a large share of food supply.

The versatile youngsters are significantly younger than the rest of the farmers and might be ascribed to be rather shaped by the multifunctional aspect of agriculture which politics increasingly focus on since the 2000s (Nègre, 2020) and intend to reinforce for the new CAP period (Massot, 2020a). They show the highest share of diversification (67\%) within the sample, indicating that they might be open for new concepts of income generation within the business. Still, they have a large amount of land at their disposal (429 ha), accounting for the cultivation of a significant share of agricultural land of the country. Combining this with the information that $45 \%$ of them are engaged in agricultural contraction activities or wage services, it can be concluded that many of the versatile youngsters react to current trends and turn them into a business. For example, carrying out individual tasks for colleagues using economies of scale to cope with the increasingly expensive machinery and facilities (DBV, 2019). Another distinguishing feature of this group is their high level of education. In line with proceeding studies, it becomes evident that young farmers with a good education are more likely to follow diversification strategies (Carter, 1998, 2001; Meert et al., 2005; Barbieri and Mahoney, 2009; Grande, 2011). Thus, these farmers might be regarded as innovators within the field.

The family-based farmers might be regarded as having maintained the traditional form of family farming with a high share of family involvement within the operation. The aim to keep farming a family business is politically supported inter alia by the German agricultural social policy (BMEL, 2020a). The share of dairy farmers (74\%) is dominating within 
this group. Since 1984, this sector has been subject to strong market intervention by the EU milk production quota (EC, 2020a). The abolishment of the quota in 2015 led to an increased competition within this sector. In this context, many dairy farmers converted their way of production to organic farming to achieve higher prices for their products (BLE, 2020). This might explain the slightly higher share of organic farmers (14\%) in this group compared to the others. The dairy sector faced and is still facing a strong process of intensification of production (FAO, 2018). The fact that the family-based farmers utilize the least amount of land (163 ha) suggests that they long for land growth to a lesser extent. Many farmers of this group might react to the high competition for agricultural land (FAO, 2003; Smith et al., 2010) with intensification in animal husbandry, in most cases dairy. Furthermore, from the high number of family members working in the business it might be concluded that family-based farmers aim at sustaining the farm as the center of their family life. This may demonstrate that keeping farming as a family business is a clear objective also from within agriculture.

\subsection{Implications for future agricultural policies}

What can we learn from the clusters within the current debate about the future of agricultural policy design, concretely the European Green Deal with its Farm to Fork Strategy and the upcoming CAP period post 2020? The three identified clusters of farmers can be regarded as a result of internal and external factors, agricultural policy as one important factor. Each group and their characteristics allow the conclusion that farmers react differently to policy interventions and show varying levels of susceptibility to political incentives also among the groups. While the conventional growers seem to orient their business strategies towards economically optimizing the offered alternatives (and thus appear to be especially receptive to subventions, as in the case of renewable energy), the versatile youngsters appear to cope differently with the changing framework conditions. A high share of them pursues diversification activities and practice arable farming as agricultural focus. This might lead to the conclusion that many of them find their own way seizing market opportunities, exploiting new areas, without becoming too dependent on political decisions. These farmers might require a greater degree of freedom in order to shape their businesses. Regarding the family-based farmers with their high number of family support within the business and many of them living in a firm partnership operating on a comparable small amount of land, any policies ensuring fair conditions to run the farm independently with 
the help of family workers, and in most cases with dairy production, appears to be acceptable.

All three farmer groups are existent and thus are important to reach the aims of agricultural policies. The conventional growers appear to be especially receptive for efficiency oriented policies towards securing food supply, which is a traditional target of the CAP (Massot, 2020b). The versatile youngsters might function for pushing forward innovations as demanded for within the context of agricultural entrepreneurship (Massot, 2020a). The family-based farmers, with their family structures, might be valuable actors in the context of maintaining vivid rural areas and the conservation of cultural landscapes (Grethe et al., 2018). Independent from the topic, farmers need to be addressed accordingly. In the following, the attempt is made to derive implications from the cluster results regarding current policy aims, as reflected in the EU Farm to Fork Strategy (EC, 2020b).

Due to their profile, including mainly traditional ways of production and income optimizing activities offered by politics, the conventional growers might react sensitive towards changes in politics. The immense intensification and specialization the agricultural sector faced over the past decades (Abson, 2019; Blaxter and Robertson, 1995; Bowler, 1986; Ilbery and Bowler, 1998; Levers et al., 2016) becomes visual especially within this group. Accordingly, it might be argued that they have a stake in continuing this path and thus, being also interested in precision agriculture and digital technologies as requested within the Farm to Fork Strategy (EC, 2020b). To attract conventional growers for designing policy programs in the area of animal welfare it seems important to center aspects of economy and productivity as from their business profiles of traditional strands of production and renewable energies subsidized by politics as well as a high increase in arable land might be concluded. This could be through financial support for modification within existing systems or for the building of new barns. Compensation for keeping less animals or for investing more time and money appears to be reasonable. To be accepted and adopted by the conventional growers and farmers in general, policies aiming at preventing nutrient losses and reducing chemical pesticides should be in line with good agricultural practice as most farmers have received some form of vocational training in agriculture and thus can be regarded as professionals within their field. Reduction targets and new rules should be plausible and economically justifiable in order to achieve a proper implementation and to prevent protests, as it was the case with the new fertilizer ordinance (ARD, 2019). 
Additionally, for the conventional growers, alternative farming strategies with regards to prohibiting certain pesticides and slurry application should be identified and presented. From the group characteristics it can be concluded that these farmers need secure options to maintain an efficient production of agricultural goods, which in turn is important for food security as a historical target of CAP (Massot, 2020b). Furthermore, due to their already present involvement in the production of renewable energy, these implementations can constitute a basis for further development. Regarding biogas plants, existing research on the implementation of the primarily use of manure to limit greenhouse gas emissions can be used in order to achieve a shift from the use of plants like maize. According to Majer et al. (2019) two thirds of the existing manure potentials are still unused in Germany. By securing a basis for profitability in the form of funding or bonus for re-engineering, the conventional growers might present a promising target group to be addressed. The same applies to wind and solar plants in which Germany takes up a leading position worldwide with a share of $42 \%$ of the total German energy supply (Bocksch, 2020) but is at the same time highly controversial among citizens (Dugstad, 2020).

The manifold diversification activities of the versatile youngsters indicate that they might be able to show a higher resilience and flexibility, for instance with respect to climate change, changing policies and market pressure (Lin, 2011; Urruty, 2016; Zilberman et al., 2018). Also, through their high education level, they might represent a fertile ground for the discussion, development and testing of new ways of production as it applies to the area of sustainability, new green business models or sustainable livestock farming (EC, 2020b). By doing so, they might inspire other farmers to adapt new technologies and ways of production as well. Thus, these farmers should be offered a sufficient amount of freedom and support to develop, test and implement new ways.

Within their everyday work, the policy issues of an increase in animal welfare and sustainable livestock farming might impact the family-based farmers most widely. Programs should center the surplus for the animals as well as the surplus for their family members. This might be for example due to facilitated workflows throughout new, animal-friendly techniques. Additionally, the economic aspect should be considered as well to be able to sustain the farm. Therefore, a financial surplus or at least compensation should be gained. Many of the family-based farmers work on venues with comparably poor soil quality and much rain. $15 \%$ are engaged in forestry and $18 \%$ in agricultural contraction activities or wage services, $12 \%$ in alternative marketing and distribution channels. This implies that in 
order to maintain the business as basis of existence for their families, they might be open to include additional activities related to their main business hitting the goal of an increased multifunctional agriculture (Massot, 2020a). From already-present engagement in forestry, the way to engage in new methods like agroforestry (EUCO, 2020) might be shorter if this implies a surplus for the continuation of the family business.

Another prominent target of future agricultural politics is the promotion of organic farming (EC, 2019; EC, 2020b). The present results reveal that among German farmers there appears to be no special target group to be addressed in this respect. All three groups contain organic farmers to roughly comparable extents (8-14\%). This indicates that to achieve this aim, all three groups should be addressed uniquely according to their priorities and targets; the conventional growers as a possibility to increase returns, the versatile youngsters as a component in the context of entrepreneurship and innovations, and the family-based farmers as a possibility to enhance their family business.

\subsection{Clusters in the context of existing literature}

When comparing the present clusters with the existing literature on farmer typologies it emerges that one of the main differences is that only quantitative variables are used independent from any relation towards special policies (Huynh et al., 2014; Morris et al., 2017) or strategy focus like diversification (Nickerson et al., 2001; García-Arias et al., 2015; Weltin et al., 2017). Furthermore, a comprehensive farmer sample across a whole country is chosen instead of certain regions or special groups.

Regarding the farmer clusters of the study at hand, it becomes evident that there are some aspects which are always present and thus can be found in other cluster approaches as well. There are often some more conservative or traditional farmer groups and mostly younger ones who are open for change and new ways of production (Lauwere, 2005; McElwee, 2008; Weltin et al., 2017) as can also be found in the present clustering. As a result of their cluster analysis, Weltin et al. (2017) find a group of small-scale livestock specialists often pursuing on-farm diversification activities roughly comparable with the family-based farmers. Their intensive livestock professionals accounting for the most intensive agricultural production and being the least likely to diversify may be comparable to the conventional growers. However, in their clustering the intensive livestock professionals employ more family workers than the small-scale livestock specialists. The conventional growers might be roughly compared to the maximizing and the optimizing production groups of the 
study of Methorst et al. (2017) for which energy production is also a possibility for development, the versatile youngsters might be the most comparable to the diversifying production group. Regarding the taxonomy of McElwee (2008), the versatile youngsters might be compared to the farmer as entrepreneur who is innovative and opportunity oriented and pursues changing, flexible and diverse economic activities. This is what Lauwere (2005) calls "real" entrepreneurs. They might be also roughly compared to the younger educated diversifiers identified by Nainggolan et al. (2013). Huynh et al. (2014) identify a group of mixed farming professionals which in terms of education, age and farm size (ha) be compared to the versatile youngsters as well. Additionally they identify a group of livestock professionals which pursue intensive livestock farming reminding of the conventional growers and the family-based farmers. All mentioned groups are just roughly and in parts comparable to the clusters at hand as the used approach is quite novel with regards to the chosen basic quantitative variables, sample size and study region.

\section{Conclusions}

Agricultural policy design is a much discussed topic entailing far-reaching consequences. Within the EU, there is currently a vivid debate about the European Green Deal with its Farm to Fork Strategy and the related future of CAP post 2020. In this context, it is of particular interest how these rather general policy guidelines at EU level can be designed and implemented effectively in the respective member countries. A crucial pre-requisite for this is to understand the structure of farmers in a comprehensive and objective way. While most studies in the literature dealing with farmer classification include qualitative and subjective variables and focus on a specific topic, their results hence depend on the respondents' opinions and a researcher bias to a certain extent. Therefore, the aim of our study was to analyze the structure of German farmers on the basis of a large survey, comprising of a wide range of objective variables regarding their personal, farm and context characteristics, by using an unsupervised machine learning approach, namely PAM clustering.

According to the results of the cluster analysis, the farmers in the sample can be clustered into three different groups: conventional growers $(\mathrm{N}=224)$, versatile youngsters $(\mathrm{N}=375)$, and family-based farmers $(\mathrm{N}=213)$. The conventional growers in particular appear to welcome efficient agricultural production and food security. For politicians, it might be concluded that these farmers are actually sensible towards those policy changes, which explicitly address these motives, as well as receptive towards incentives. For them, 
the economic aspect within policy programs should be put into the center, also in terms of communicating the farm-level advantages of these programs towards farmers. To deal with and to adapt changing policy requirements, it seems to be important for them that they are offered new solutions instead of sole prohibitions and new thresholds.

The versatile youngsters might be regarded as innovators within the field. They appear to be a promising target group to discuss, test, and implement new ways of production and to develop policy programs in the first place. For doing so, they should be offered a certain degree of freedom and support by policy makers. Once new things are tested by this group, other farmers might follow by implementing new ways of production as well.

From a policy perspective, it might be concluded that the family-based farmers aim at sustaining the farm as a family business and thus demand specific policies that enable this. As long as this goal is achieved, they seem to be open for change. With their rather small family structures, they might constitute important actors with regards to the remaining of vivid rural areas and cultural landscapes.

Finally, the design of future agricultural policy in the context of the Farm to Fork Strategy and CAP post 2020 needs to consider these different farmer groups and their specific profiles. Policy programs, such as the national design of the CAP and Farm to Fork Strategy, should offer certain degrees of freedom; new business models and sustainable farming as well as second pillar programs might be developed and tested together with the versatile youngsters. Furthermore, aspects ensuring an effective and economically rewarding production of agricultural goods should be taken into account to offer a perspective for the conventional growers and for food security. Moreover, farming models which can be run independently appear to be important for the family-based farmers who also constitute a promising target group for rural development programs.

This study offers a basis for future agricultural policy design. A clear limitation is that although the clustering on the basis of hard facts and quantitative data generally represents a solid fundament, deeper explanations of reasons and motives are missing. This basis can be used for further research of exploring deeper reasoning and, for instance, engaging in focus group discussions with the different farmer types. This also constitutes the starting point for policy design. Furthermore, a comparable clustering could be conducted in other European countries as well in order to design country-specific programs. Another limitation lays in the fact that, although the investigated sample is large compared to other studies and comprises of farmers from a high regional coverage in Germany, it still deviates slight- 
II Farmer typology and implications for policy design - An unsupervised machine learning approach

ly in some variables from German agricultural structure surveys. Representativeness could still be improved especially with regards to farm size and education.

\section{CRediT authorship contribution statement}

Viktoria Graskemper: Conceptualization, Investigation, Data Curation, Writing - original draft. Xiaohua Yu: Methodology, Software, Formal analysis. Jan-Henning Feil: Conceptualization, Writing - review \& editing, Supervision.

\section{Acknowledgements}

We would like to thank Andreas Quiring of the Andreas Hermes Akademie for his valuable comments. We gratefully acknowledge financial support from the German Research Foundation (DFG), Grant ID 265161039.

\section{Declarations of interest}

None. 


\section{References}

Abson, D.J. Chapter 19 - The Economic Drivers and Consequences of Agricultural Specialization. In: Lemaire, César de Faccio Carvalho et al. 2019 - Agroecosystem diversity, pp. 301-315.

Andersen, E., Elbersen, B., Godeschalk, F., Verhoog, D., 2007. Farm management indicators and farm typologies as a basis for assessments in a changing policy environment (eng). J. Environ. Manag. 82 (3), 353-362.

ARD (Arbeitsgemeinschaft der öffentlich-rechtlichen Rundfunkanstalten der Bundesrepublik Deutschland), 2019. Protest von Bauern - Tausende Trecker legen Städte lahm. https://www.tagesschau.de/inland/bauern-protest-101.html.

Barbieri, C., Mahoney, E., 2009. Why is diversification an attractive farm adjustment strategy? Insights from Texas farmers and ranchers. J. Rural Stud. 25 (1), 58-66. https://doi.org/10.1016/j.jrurstud.2008.06.001.

Blaxter, K., Robertson, N., 1995. From dearth to plenty: the modern revolution in food production. Cambridge University Press, Cambridge.

BLE (Bundesanstalt für Landwirtschaft und Ernährung), 2020. Milchviehhaltung in Deutschland. https://www.praxis-agrar.de/tier/rinder/milchviehhaltung-in-deutschland/.

BMEL (Bundesanstalt für Landwirtschaft und Ernährung), 2020a. Agrarsozialpolitik. https://www.bmel.de/DE/themen/landwirtschaft/agrarsozialpolitik/agrarsozialpolitik_no de.html.

BMEL (Bundesanstalt für Landwirtschaft und Ernährung), 2020b. Gemeinsame Agrarpolitik (GAP). https://www.bmel.de/DE/themen/landwirtschaft/eu-agrarpolitik-undfoerderung/gap/gap_node.html.

Bocksch, R., 2020. Deutschland führend bei Wind und Solar, https://de.statista.com/infografik/22576/anteil-von-wind-und-solarenergie-an-derstromerzeugung/. (Accessed: 15 December 2020).

Carter, S., 1998. Portfolio entrepreneurship in the farm sector: indigenous growth in rural areas? Entrep. Reg. Dev. 10 (1), 17-32. https://doi.org/10.1080/08985629800000002. 
Carter, S., 2001. Multiple business ownership in the farm sector - differentiating monoactive, diversified and portfolio enterprises. Int. J. Entrep. Behav. Res. 7 (2), 43-59. https://doi.org/10.1108/13552550110695552.

Cullen, P., Ryan, M., O'Donoghue, C., Hynes, S., hUallacháin, D.Ó., Sheridan, H., 2020. Impact of farmer self-identity and attitudes on participation in agri-environment $\begin{array}{lllll}\text { schemes. } & \text { Land } & \text { Use }\end{array}$ https://doi.org/10.1016/j.landusepol.2020.104660.

Daloğlu, I., Nassauer, J.I., Riolo, R.L., Scavia, D., 2014. Development of a farmer typology of agricultural conservation behavior in the American Corn Belt. Agric. Syst. 129, 93-102. https://doi.org/10.1016/j.agsy.2014.05.007.

Darnhofer, I., Schneeberger, W., Freyer, B., 2005. Converting or not converting to organic farming in Austria: farmer types and their rationale (en). Agric. Hum. Values 22 (1), 39-52. https://doi.org/10.1007/s10460-004-7229-9.

DBV (Deutscher Bauernverband), 2018. Situationsbericht 2018/19: Trends und Fakten zur Landwirtschaft, Berlin.

DBV (Deutscher Bauernverband), 2019. Situationsbericht 2019/20: Trends und Fakten zur Landwirtschaft, Berlin.

Dugstad, A., Grimsrud, K., Kipperberg, G., Lindhjem, H., Navrud, S., 2020. Acceptance of wind power development and exposure - not-in-anybody's-backyard. Energy Policy $147,111780$.

EC (European Commission), 2019. From Farm to Fork: The European Green Deal. Publications Office of the European Union, Luxembourg.

EC (European Commission), 2020a. Milk and dairy products. https://ec.europa.eu/info/food-farming-fisheries/animals-and-animal-products/animalproducts/milk-and-dairy-products_en\#documents.

EC (European Commission), 2020b. Farm to Fork Strategy: For a fair, healthy and environmentally-friendly food system. COM, 2020381 final, Brussels.

EC (European Commission), 2020c. CAP expenditure in the total EU expenditure: Common Agricultural Policy: Key graphs \& figures. https://ec.europa.eu/info/sites/info/files/food-farming-fisheries/farming/documents/capexpenditure-graph1_en.pdf. (Accessed: 17 November 2020). 
EEC (European Economic Community), 1957. Vertrag zur Gründung der Europäischen Wirtschaftsgemeinschaft. https://eur-lex.europa.eu/legalcontent/DE/TXT/PDF/?uri=CELEX:11957E/TXT\&from=DE (accessed 17 November 2020).

EU2020, 2020. Von Eco-Schemes bis zu nationalen Strategieplänen: Was sich durch die Reform der Gemeinsamen Agrarpolitik der EU ändern soll. https://www.eu2020. de/eu2020-de/aktuelles/artikel/eu-staaten-einigen-sich-auf-reform-der-agrarpoliti k/2408636. (Accessed: 17 November 2020).

FAO (Food and Agriculture Organization of the United Nations), 2018. Dairy and dairy products. In: OECD, FAO (Eds.), agricultural outlook 2018-2027, Rome, pp. 163-174.

FAO (Food and Agriculture Organization of the United Nations), 2003. Overview of Land Value Conditions. AGL Miscellaneous Paper 35/2003. FAO, Rome.

García-Arias, A.-I., Vázquez-González, I., Sineiro-García, F., Pérez-Fra, M., 2015. Farm diversification strategies in northwestern Spain: factors affecting transitional pathways. Land Use Policy 49, 413-425. https://doi.org/10.1016/j. landusepol.2015.08.011.

Gower, J.C., 1971. A general coefficient of similarity and some of its properties. Biometrics 27 (4), 857-871. https://doi.org/10.2307/2528823.

Grande, J., 2011. New venture creation in the farm sector - critical resources and capabilities. J. Rural Stud. 27 (2), 220-233. https://doi.org/10.1016/j.jrurstud.2011.02.003.

Grethe, H., Arens-Azevedo, U., Balmann, A., Biesalski, H.K., Birner, R., Bokelmann, W., Christen, O., Gauly, M., Knierim, U., Latacz-Lohmann, U., Martinez, J., Nieberg, H., Offermann, F., Pischetsrieder, M., Qaim, M., Renner, B., Schmid, J., Spiller, A., Taube, F., Voget-Kleschin, L., Weingarten, P., 2018. Für eine gemeinwohlorientierte Gemeinsame Agrarpolitik der EU nach 2020: Grundsatzfragen und Empfehlungen. (de). Berichte über Landwirtschaft (Sonderheft 225). doi:10.12767/BUEL.V0I225.

Guarín, A., Rivera, M., Pinto-Correia, T., Guiomar, N., Šūmane, S., Moreno-Pérez, O.M., 2020. A new typology of small farms in Europe. Glob. Food Secur. 26, 1-9.

Huynh, T.H., Franke, C., Piorr, A., Lange, A., Zasada, I., 2014. Target groups of rural development policies: development of a survey-based farm typology for analysing selfperception statements of farmers (English). Outlook Agric. 43 (2), 75-83. 
Ilbery, B.W., 1991. Farm diversification as an adjustment strategy on the urban fringe of the West Midlands. J. Rural Stud. 7 (3), 207-218. https://doi.org/10.1016/07430167(91)90085-7.

Ilbery, B., Bowler, I., 1998. From agricultural productivism to post-productivism (English). In: Ilbery, B. (Ed.), The Geography of Rural Change. Routledge, London.

Kassambara, A., 2017. Practical Guide To Cluster Analysis in R: Unsupervised Machine Learning (eng), first ed. STHDA, France, p. 187.

Kuhn, T., Schäfer, D., 2018. A Farm Typology for North Rhine-Westphalia to Assess Agri-environmental Policies. Discussion Paper 2018:1. University of Bonn.

Lauwere, C.C. de, 2005. The role of agricultural entrepreneurship in Dutch agriculture of today. Agric. Econ. 33 (2), 229-238. https://doi.org/10.1111/j.1574-0862.2005.00373.x.

Lesmeister, C., 2015. Mastering Machine Learning with R: Master machine learning techniques with R to deliver insights for complex projects, Birmingham, UK.

Levers, C., van Butsic, Verburg, P.H., Müller, D., Kuemmerle, T., 2016. Drivers of changes in agricultural intensity in Europe. Land Use Policy 58, 380-393.

Lin, B.B., 2011. Resilience in agriculture through crop diversification: adaptive management for environmental change. BioScience 61 (3), 183-193.

Madhulatha, T.S., 2012. An overview on clustering methods. IOSR J. Eng. 02 (04), 719725.

Majer, S., Kornatz, P., Daniel-Gromke, J., Rensberg, N., Brosowki, A., Oehmichen, K., Liebetrau, J., 2019. Stand und Perspektiven der Biogaserzeugung aus Gülle, Leipzig.

Massot, A., 2020a. Die künftige Gemeinsame Agrarpolitik nach 2020. https://www.europarl.europa.eu/ftu/pdf/de/FTU_3.2.9.pdf.

Massot, A., 2020b. The common agricultural policy (CAP) and the Treaty: Fact Sheets on the European Union. https://www.europarl.europa.eu/factsheets/en/sheet/103/thecommon-agricultural-policy-cap-and-the-treaty.

McElwee, G., 2008. A taxonomy of entrepreneurial farmers. Int. J. Entrep. Small Bus. 6 (3), 465-478.https://doi.org/10.1504/IJESB.2008.019139. 
McFadden, T., Gorman, M., 2016. Exploring the concept of farm household innovation capacity in relation to farm diversification in policy context. J. Rural Stud. 46, 60-70. https://doi.org/10.1016/j.jrurstud.2016.05.006.

Meert, H., van Huylenbroeck, G., Vernimmen, T., Bourgeois, M., van Hecke, E., 2005. Farm household survival strategies and diversification on marginal farms. J. Rural Stud. 21 (1), 81-97. https://doi.org/10.1016/j.jrurstud.2004.08.007.

Methorst, R.G., Roep, D., Verhees, F.J.H.M., Verstegen, J.A.A.M., 2017. Differences in farmers' perception of opportunities for farm development. NJAS Wagening. J. Life Sci. 81, 9-18. https://doi.org/10.1016/j.njas.2017.02.001.

Morris, W., Henley, A., Dowell, D., 2017. Farm diversification, entrepreneurship and technology adoption: analysis of upland farmers in Wales. J. Rural Stud. 53, 132-143. https://doi.org/10.1016/j.jrurstud.2017.05.014.

Nainggolan, D., Termansen, M., Reed, M.S., Cebollero, E.D., Hubacek, K., 2013. Farmer typology, future scenarios and the implications for ecosystem service provision: a case study from south-eastern Spain. Reg. Environ. Change 13 (3), 601-614. https://doi.org/10.1007/s10113-011-0261-6.

Nègre, F., 2020. Second pillar of the CAP: rural development policy. https://www.europarl.europa.eu/factsheets/en/sheet/110/second-pillar-of-the-cap-ruraldevelopment-policy.

Nickerson, N.P., Black, R.J., McCool, S.F., 2001. Agritourism: motivations behind farm/ ranch business diversification. J. Travel Res. 40 (1), 19-26. https://doi.org/10.1177/004728750104000104.

Smith, P., Gregory, P.J., van Vuuren, D., Obersteiner, M., Havlík, P., Rounsevell, M., Woods, J., Stehfest, E., Bellarby, J., 2010. Competition for land (eng). Philosophical transactions of the Royal Society of London. Ser. B Biol. Sci. 365 (1554), 2941-2957.

The Economist, 2020. A future for the eu's common agricultural policy. https://foodsustainability.eiu.com/a-future-for-the-eus-common-agricultural-policy/.

UBA (Umweltbundesamt), 2019. Erneuerbare-Energien-Gesetz. https://www.umweltbundesamt.de/themen/klima-energie/erneuerbareenergien/erneuerbare-energien-gesetz\#erfolg. 
Urruty, N., Tailliez-Lefebvre, D., Huyghe, C., 2016. Stability, robustness, vulnerability and resilience of agricultural systems. A review. Agron. Sustain. Dev. 36 (1), 15.

Venghaus, S., Acosta, L., 2018. To produce or not to produce: an analysis of bioenergy and crop production decisions based on farmer typologies in Brandenburg, Germany. Reg. Environ. Change 18 (2), 521-532.

Vesala, H.T., Vesala, K.M., 2010. Entrepreneurs and producers: identities of finnish farmers in 2001 and 2006. J. Rural Stud. 26 (1), 21-30. https://doi.org/10.1016/j.jrurstud.2009.06.001.

Vik, J., McElwee, G., 2011. Diversification and the entrepreneurial motivations of farmers in Norway. J. Small Bus. Manag. 49 (3), 390-410. https://doi.org/10.1111/j.1540627X.2011.00327.x.

Weltin, M., Zasada, I., Franke, C., Piorr, A., Raggi, M., Viaggi, D., 2017. Analysing behavioural differences of farm households: an example of income diversification strategies based on European farm survey data. Land Use Policy 62, 172-184. https://doi.org/10.1016/j.landusepol.2016.11.041.

Zilberman, D., Lipper, L., McCarthy, N., Gordon, B., 2018. Innovation in response to climate change. In: Lipper, L., McCarthy, N., Zilberman, D., Asfaw, S., Branca, G. (Eds.), Climate Smart Agriculture - Building Resilience to Climate Change. Springer International Publishing, pp. 49-74. 


\section{Appendix 1}

Information on the survey design and description variables used for the cluster analysis

Information shaded in grey was not displayed to the participants and describes the coding of the variables used for the cluster analysis.

\section{Appendix 1a: Survey introduction}

\section{Survey on the topic of "Entrepreneurship in Agriculture"}

Dear farmer,

Is the future of agriculture really a question of "grow or give way"?

What is the role of the farmer as an entrepreneur?

These crucial questions are not only asked by us farmers, but also by advisors and politicians who are desperately looking for clues on how to shape the future of agriculture.

By responding to this survey, you will help to examine agricultural entrepreneurship in general and the factors that influence it. We will look at 1. the farm you run, 2. yourself as farm manager or farm successor, and 3. the context. This will be done from different perspectives - also interesting for you.

Thank you very much for your help and we hope you enjoy answering the questions.

\section{Target group filter}

Are you primarily responsible for the management and development of a farm?
$1 \quad \circ \quad$ Yes
0
- No
$\rightarrow$ end of the survey 


\section{Appendix 1b: Variables on farm characteristics used in the analysis}

\section{fulltime}

The farm is run...
$0 \quad \circ$ part-time
$1 \quad \circ$ full-time

\section{organic}

Is the farm run in a conventional organic way of production?
$0 \quad \circ$ conventional
$1 \quad 0$ organic

\section{wf_family}

How many family workers are employed in the operation (yourself included)?

\section{cooperation}

In what way do you cooperate with other farmers on the farm?

$1 \bigcirc$ cooperation in markets through producer or purchasing groups

$1 \bigcirc$ division of labour through contractually regulated neighbourhood assistance, machinery rings or management contracts

$1 \quad \circ$ joint use of machinery by fractional communities or machinery companies

$1 \quad \bigcirc$ joint management through joint use of facilities (e.g. warehouses, drying facilities etc.), joint stables or operating (branch) companies (e.g. GbR, GmbH)

$0 \quad \circ \quad$ I do not work with other farmers in any of these ways.

foc_variables $(0-1)$

What is the main focus of the farm you run?

If the holding does not belong to a form of agricultural specialisation (>2/3 of gross agricultural production in $€$ ), please select more than one orientation.

Multiple answers are possible. 
II Farmer typology and implications for policy design - An unsupervised machine learning approach
foc_arable
○ arable farming (cereals, pulses, potatoes, sugar beet, industrial crops, field vegetables, fodder crops, seeds, hops)
foc_horti
○ horticulture (total horticultural products including nursery products)
foc_perma
○ permanent crops (vineyards, orchards, other permanent crops)
foc_fordairy
$\circ$ forage crops and dairy cattle (dairy cows)
foc_foroth
other forage crops (breeding and fattening cattle, sheep, goats, horses)
foc_refine
$\circ$ refinement (pigs, poultry)

size

How many hectares of agricultural land does the holding have?

This includes arable land, permanent crops and permanent grassland. ha owned land ha leased land

\section{size_initial}

How many hectares of agricultural land did the farm have when you started working there?

This includes arable land, permanent crops and permanent grassland. ha owned land ha leased land

\section{diversification variables}

Does your company have areas of activity that differ from traditional agricultural production activities? If so, to which of the areas below can these activities be assigned?

Multiple answers are possible.
div_agr
○ cultivation of unconventional crops
div_agr
○ keeping unconventional animal breeds
div_agr
$\circ$ forestry
div_agr
- agricultural contraction activities, wage services
div_str
$\circ$ overnight accommodation
div_str
- leisure activities 
II Farmer typology and implications for policy design - An unsupervised machine learning approach
div_str
- alternative marketing and distribution channels
div_str
$\bigcirc$ processing of agricultural products
div_str
○ solidary / social / educational activities
div_str
○ letting of farm buildings for non-agr. purposes
div_str
○ letting of real estate for residential purposes
div_str
○ letting of land for non-agricultural purposes

\section{rain and soil}

Please indicate the average number of soil points and rainfall at the core farm.

In the case of several widely scattered sites, the core operation refers to the initial agricultural operation. soil points rainfall in $\mathrm{mm} /$ year

\section{central}

Is your agricultural main site located near a metropolitan area or tourist recreation region?
$1 \quad 0$ yes
$0 \quad 0$ no

west

In which federal state is the farm located?
$1 \quad \circ$ Bremen
1 ○ Hamburg
$0 \quad \circ$ Berlin
$1 \quad \circ \quad$ Saarland
$1 \quad \circ$ Schleswig Holstein
$0 \quad \bigcirc$ Thuringia
$0 \quad \circ$ Saxony
$1 \quad \circ$ Rhineland Palatinate
$0 \quad \circ$ Saxony-Anhalt
$1 \quad \circ$ Hesse 
II Farmer typology and implications for policy design - An unsupervised machine learning approach
$0 \quad \circ$ Mecklenburg Western Pomerania
$0 \quad \circ$ Brandenburg
$1 \quad \circ$ North Rhine-Westphalia
$1 \quad \circ$ Baden-Württemberg
$1 \quad \circ$ Lower Saxony
$1 \quad \circ$ Bavaria

\section{Appendix 1c: Variables on farmer and context characteristics used in the analysis}

\section{male}

What is your gender?
$0 \quad \circ$ female
$1 \quad \circ$ male

age

Please select your year of birth.

- Scroll-down-list and calculation of age by subtraction -

\section{partnership}

What is your marital status?
$1 \quad 0$ married (or registered partnership) and living together with my spouse
$0 \quad \circ$ married (or registered partnership) and separated from my spouse
$1 \quad \circ$ in a permanent partnership
$0 \quad 0$ divorced
$0 \quad \circ$ widowed
$0 \quad \circ$ single

\section{wf_spouse}

Does your spouse work within the operation?
1
$\circ$ yes
0
○ no 
II Farmer typology and implications for policy design - An unsupervised machine learning approach

\section{degree}

Please select ALL vocational training qualifications you have acquired.

$0 \quad \bigcirc$ vocational-business or vocational-school training (apprenticeship, vocational school, college)

$0 \quad \circ$ preparatory service for the middle civil service in the public administration

$0 \quad \bigcirc$ completion of a technical college, master craftsman's college, technical college, administration and business academy or specialist academy

$1 \quad \circ$ Bachelor

$1 \quad 0$ Master

$1 \quad \circ$ Diploma

$0 \quad \circ$ Master, Magister, State Examination

$1 \bigcirc \mathrm{PhD}$

$0 \quad \bigcirc$ other professional qualification

$0 \quad \circ$ no professional qualification

\section{edu_agr}

Is this vocational training in agriculture, viticulture or horticulture?
$1 \quad \circ \quad$ Yes
$0 \quad \circ \quad \mathrm{No}$

\section{childhood}

How did you relate to agriculture in your childhood?
$1 \quad \circ$ grown up on a farm
$2 \quad 0$ farm in the wider family
$3 \quad 0$ working on neighbour farm
$4 \quad \circ$ no relation to agriculture

\section{job}

Are you currently working outside the farm you are currently managing?
1
○ yes
0
○ no 
II Farmer typology and implications for policy design - An unsupervised machine learning approach

\section{Appendix 1d: End of the survey}

...Done!

Thank you very much for sticking it out until the end.

Selected evaluation results will be available not only in scientific but also in agricultural media from mid-2019 onwards. 
II Farmer typology and implications for policy design - An unsupervised machine learning approach

\section{Appendix 2}

Table A.2: PAM results: characteristics of different farmer groups with renewable energy as element of structural diversification

\begin{tabular}{|c|c|c|c|c|}
\hline & $\begin{array}{l}\text { Conventional } \\
\text { growers }\end{array}$ & $\begin{array}{l}\text { Versatile } \\
\text { youngsters }\end{array}$ & $\begin{array}{l}\text { Family-based } \\
\text { farmers }\end{array}$ & $\begin{array}{l}\text { Overall } \\
\text { significance }\end{array}$ \\
\hline & $\mathrm{N}=343$ & $\mathrm{~N}=272$ & $\mathrm{~N}=197$ & \\
\hline \multicolumn{5}{|l|}{ Farmer } \\
\hline age & $38.7(13.8)$ & $36.1(11.4)$ & $40.8(12.8)$ & $<0.001$ \\
\hline male & $0.86(0.35)$ & $0.83(0.38)$ & $0.85(0.36)$ & 0.568 \\
\hline degree & $0.27(0.45)$ & $0.75(0.43)$ & $0.21(0.41)$ & $<0.001$ \\
\hline edu_agr & $0.89(0.31)$ & $0.89(0.31)$ & $0.86(0.34)$ & 0.603 \\
\hline partnership & $0.70(0.46)$ & $0.72(0.45)$ & $0.87(0.33)$ & $<0.001$ \\
\hline job & $0.12(0.32)$ & $0.61(0.49)$ & $0.19(0.40)$ & $<0.001$ \\
\hline childhood & $1.23(0.67)$ & $1.24(0.63)$ & $1.26(0.70)$ & 0.891 \\
\hline \multicolumn{5}{|l|}{ Farm } \\
\hline size & 331 (647) & $384(717)$ & $195(462)$ & 0.005 \\
\hline size_initial & $251(568)$ & $332(705)$ & $136(368)$ & 0.002 \\
\hline fulltime & $0.93(0.26)$ & $0.79(0.41)$ & $0.88(0.33)$ & $<0.001$ \\
\hline organic & $0.09(0.28)$ & $0.15(0.36)$ & $0.10(0.30)$ & 0.028 \\
\hline foc_arable & $0.86(0.35)$ & $0.83(0.37)$ & $0.20(0.40)$ & $<0.001$ \\
\hline foc_fordairy & $0.14(0.35)$ & $0.18(0.38)$ & $0.79(0.41)$ & $<0.001$ \\
\hline foc_foroth & $0.17(0.38)$ & $0.17(0.38)$ & $0.15(0.36)$ & 0.736 \\
\hline foc_refine & $0.43(0.50)$ & $0.27(0.45)$ & $0.17(0.37)$ & $<0.001$ \\
\hline foc_horti & $0.03(0.18)$ & $0.01(0.12)$ & $0.01(0.10)$ & 0.100 \\
\hline foc_perma & $0.07(0.26)$ & $0.06(0.24)$ & $0.06(0.23)$ & 0.806 \\
\hline div_agr & $0.27(0.45)$ & $0.79(0.41)$ & $0.30(0.46)$ & $<0.001$ \\
\hline div_str & $0.76(0.43)$ & $0.74(0.44)$ & $0.73(0.44)$ & 0.756 \\
\hline soil & $49.1(18.8)$ & $47.9(17.8)$ & $42.8(15.7)$ & $<0.001$ \\
\hline rain & $685(160)$ & $686(180)$ & 756 (217) & $<0.001$ \\
\hline west & $0.84(0.37)$ & $0.82(0.39)$ & $0.93(0.25)$ & 0.001 \\
\hline central & $0.12(0.32)$ & $0.11(0.31)$ & $0.08(0.27)$ & 0.376 \\
\hline \multicolumn{5}{|l|}{ Context } \\
\hline wf_family & $1.85(1.15)$ & $1.71(1.07)$ & $2.16(1.06)$ & $<0.001$ \\
\hline wf_spouse & $0.23(0.42)$ & $0.27(0.44)$ & $0.65(0.48)$ & $<0.001$ \\
\hline coop & $0.73(0.44)$ & $0.84(0.37)$ & $0.76(0.43)$ & 0.006 \\
\hline
\end{tabular}

Note: Means are presented with standard derivations in brackets, variables shaded grey differ significantly $(\mathrm{p}<0.05)$ 


\title{
III Analyzing strategic entrepreneurial choices in agriculture - Empiri- cal evidence from Germany
}

\author{
Authors: Viktoria Graskemper, Xiaohua Yu, Jan-Henning Feil \\ Published in: Agribusiness - An International Journal, 2021; 1-21. \\ https://doi.org/10.1002/agr.21691
}

\begin{abstract}
Entrepreneurship in agriculture is a phenomenon that is growing in importance with the changing framework conditions for agricultural production and has led to heterogeneity in farm business development paths. To understand this phenomenon better, a classification scheme for strategic entrepreneurial choices in agriculture is developed for family farmers. The choices that are scrutinized are reduction, continuation, expansion, diversification, and the dual strategy of expansion and diversification. Each farmer is uniquely assigned to one of these choice classes according to their implemented entrepreneurial activities. Determinants influencing these choices are investigated with a multinomial logit model. The data are derived from a quantitative survey among German farmers $(\mathrm{N}=745)$. Strong effects are observable within the area of personal factors; creativity and risk affinity benefit entrepreneurial strategies connected with diversification. Farmers with a third-level education qualification are less likely to follow expansion strategies, and those with off-farm employment and risk-averse farmers mainly choose a reduction strategy. Family involvement, especially the farmer's spouse, proves to have stabilizing and even enhancing effects on certain strategies. Implications for policymakers and actors within the agricultural sector can thus be derived.
\end{abstract}

Key Words: entrepreneurship, farming strategy, multinomial logit model, strategic entrepreneurial choices

JEL Classification: M21; Q12; Q18 


\section{$1 \quad$ Introduction}

The context in which farmers operate is subject to continuous change. Over the last decades in the European Union (EU), this was caused, inter alia, by the liberalization of the Common Agricultural Policy (CAP). From the very beginning, market support policies were an integral part of CAP. Since the 1990s, this has steadily reduced, causing an increase in competitive pressures. In addition, societal demands, consumer behavior, and desires are changing. As is seen in policy requirements, agricultural production is currently under increasingly critical public consideration (Dias et al., 2019a; Weltin et al., 2017). The CAP is fundamentally modifying and incentives are being created for multifunctional agriculture to ensure the future viability of rural areas. In fact, planned amendments to the CAP after 2020 explicitly encourage entrepreneurship within agriculture (Grethe et al., 2018). Thus, common strategies of growth and expansion of known production activities do not work for all farmers anymore, leading to heterogeneity in farm business development paths (Morris et al., 2017).

Notwithstanding the importance of entrepreneurship in agriculture, interest in this field of research has only gained more interest recently, and is still being consolidated (Dias et al., $2019 \mathrm{~b}$ ). The topics currently investigated focus on the entrepreneurial skills of farmers, and the way they exploit their resources to adapt to structural changes. Up until about a decade ago, much research effort was made to create typologies and definitions of entrepreneurial concepts. In this context, the most prominent phenomenon discussed in the literature is diversification, which is generally defined as remaining in and growing the business by moving strategically and systemically away from core activities (McElwee \& Robson, 2005). As diversification is a broadly defined concept comprising of also other more specific concepts, it has mostly been used in the respective literature to analyze the backgrounds and determinants of entrepreneurial strategies (Dias et al., 2019a, 2019b). Many of these studies focus on categorizing and describing farmers and their respective strategies, often with the help of a cluster analysis (e.g., Lauwere, 2005; Morris et al., 2017; Weltin et al., 2017). Studies dealing with conventional strategies, such as growth or decline in known areas, mostly focus on explaining structural change in retrospective (Glauben et al., 2006; Huettel \& Margarian, 2009; Viira et al., 2013; Weiss, 1999). However, studies investigating the broader range of available entrepreneurial strategies in agriculture, including growth and decline in known areas as well as diversification altogether cannot be found. 
Against this background, it is of major importance for politicians as well as decisionmakers and consultants within the sector to know which factors drive farmers' choices toward certain farming strategies. This is particularly important as many new requirements for agricultural production aim to strengthen family farms and rural areas (Grethe et al., 2018), while expanding structures and withdrawing smaller farms (Deutscher Bauernverband [DBV], 2018). To the best of the authors' knowledge, there has been no study analyzing the determinants of the whole range of strategic entrepreneurial choices in agriculture in depth. Furthermore, while most studies in the fields described above focus on European countries, Germany has rarely been investigated (Dias et al., 2019b). This study aims to fill this research gap by developing a classification scheme describing strategic entrepreneurial choices in agriculture as a basis for analyzing determinants of these choices. Data was collected from a quantitative survey among German farmers $(\mathrm{N}=745)$. The proposed classification scheme is designed especially for family farmers and makes it possible to uniquely assign them to the respective groups of implemented entrepreneurial choices according to predetermined criteria. For this reason, the classification scheme can be applied in other countries with comparable structures. The determinants of the respective choices are analyzed with the help of a multinomial logit (MNL) model.

The paper is structured as follows. To prepare a basis for the analysis, in Section 2, the classification scheme and the possible determinants of strategic entrepreneurial choices in agriculture are derived from the literature. The theoretical and empirical model as well as the data are presented in Section 3. The results are presented and discussed in Section 4. Finally, conclusions are drawn in Section 5.

\section{Conceptual framework}

As a basis for the analysis, in this section, the conceptual framework is described. First, a classification scheme is established and afterwards possible determinants of strategic entrepreneurial choices in agriculture are identified from the literature.

\subsection{Classification scheme}

First, by using the existing literature, a classification scheme describing strategic entrepreneurial choices in agriculture is developed, as illustrated in Figure 1. This is especially applicable for family farmers as it implies a deep involvement in the farm and development pathways over time and serves as the basis for the analysis of the determinants influencing 
farmers' different choices when it comes to entrepreneurial strategies. Building on the works of Bowler (1992) and Ilbery and Bowler (1998), the classifications derived by García-Arias et al. (2015) and the diverse set of farm development strategies stated by McElwee (2006), the scheme divides stagnation and growth. Stagnation refers to the reduction of farming activities and the continuation of the activities implemented by the predecessor. Growth refers to the expansion of existing activities. As expansion is deemed a rather conventional growth strategy, diversification is seen to be an innovative growth strategy. Diversification is mainly described in terms of on-farm diversification, as suggested by Weltin et al. (2017), and structural and agricultural diversification, based on the basic typology of Ilbery (1991) and adjusted for the present situation. Conventional growth and decline strategies are usually investigated separately from innovative growth strategies, such as diversification. The classification scheme combines them and additionally introduces a category of farmers who follow a dual strategy of expansion and diversification, as is illustrated in Figure 1.

\begin{tabular}{|l|l|}
\hline $\begin{array}{l}\text { Reduction } \\
\text { Decrease of owned land of more than } 20 \% \\
\text { or/and reduction of the complexity of the operation }\end{array}$ & stagnation \\
\hline $\begin{array}{l}\text { Continuation } \\
\text { No considerable change, de-/increase of owned land less than } 20 \%\end{array}$ & \\
\hline $\begin{array}{l}\text { Expansion } \\
\text { Increase of owned land of more than } 20 \% \\
\text { or/and expansion of animal husbandry } \\
\text { or/and expansion of already present diversification activities }\end{array}$ & \\
\hline $\begin{array}{l}\text { Expansion \& Diversification } \\
\text { Increase of owned land of more than } 20 \% \\
\text { or/and expansion of animal husbandry } \\
\text { or/and expansion of diversification activities started by the predecessor } \\
\text { AND start-up of diversification activities }\end{array}$ & growth \\
\hline $\begin{array}{l}\text { Diversification } \\
\text { Start-up of diversification activities }\end{array}$ & \\
\hline
\end{tabular}

Figure 1. Classification of strategic entrepreneurial choices in agriculture

Due to the fact that pursuing a reduction strategy can be as successful as pursuing an expansion strategy (Appel \& Balmann, 2018), depending on the respective situations, the division of categories does not judge any choices made by the farmer. 


\subsection{Possible determinants of strategic entrepreneurial choices in agriculture}

First of all, the existing literature on agricultural entrepreneurship, including the prevailing phenomena of diversification, pluriactivity, and portfolio entrepreneurship, as well as the literature on the growth and decline of farms, have been analyzed to identify the determinants of the strategic entrepreneurial choices in agriculture. In conformity with Bateman and Ray (1994) and García-Arias et al. (2015), these can be assigned to three fields: determinants concerning farmers; determinants concerning farm characteristics, both representing internal factors; and determinants concerning the context of the farm and the farmer, representing external factors. An overview of the possible determinants of entrepreneurship in agriculture is shown in Figure 2.

\begin{tabular}{|c|c|c|}
\hline FARMER & FARM & CONTEXT \\
\hline $\begin{array}{c}\text { Gender } \\
\text { Age } \\
\text { Education level } \\
\text { (Entrepreneurial) skills } \\
\text { Off-farm job } \\
\text { Risk attitude } \\
\text { Creativity }\end{array}$ & $\begin{array}{c}\text { Farm size } \\
\text { Environmental conditions } \\
\text { Location }\end{array}$ & $\begin{array}{c}\text { Family } \\
\text { Spouse } \\
\text { Internal institutions } \\
\text { (Values, Traditions) } \\
\text { External institutions } \\
\text { (Pressure by politics, } \\
\text { society, growth) } \\
\text { Networks }\end{array}$ \\
\hline 5 & 2 & $\sqrt{5}$ \\
\hline
\end{tabular}

Figure 2. Determinants of entrepreneurship in agriculture

\subsubsection{Determinants concerning the farmer}

The organization of the farm is motivated by the values, attitudes, and goals of the farmer (Lauwere, 2005; McElwee, 2008; McFadden \& Gorman, 2016). Farmers typically have a deep personal involvement with their farm operations, and a strong identification with agriculture (Vesala \& Vesala, 2010; Vik \& McElwee, 2011).

Agriculture is currently a male-dominated field, which has led to some studies especially investigating the role of women. Women are credited with playing leading roles in facilitating the introduction of new practices and conceptions on the farm and hence act as important innovators (Barbieri \& Mahoney, 2009; McGehee et al., 2007; Seuneke \& Bock, 2015). However, Bock (2004) finds that their entrepreneurial activity on the farm is often relatively that of a small scale and that they avoid liabilities. Along with the traditional farming activities, they not only start side-businesses but also simultaneously take care of their family. He describes the role of women in agriculture as "fitting in and multitasking" 
(Bock, 2004). Regarding men, Pindado and Sánchez (2018) observed a significant influence on growth-associated agri-entrepreneurship. That is, men are found to generally put more value on growth activities than women are (Bakucs \& Fertó, 2009; Cliff, 1998; Weiss, 1999).

One of the most frequently investigated determinants is the farmer's age. Here, the results differ. In terms of farm growth, Weiss (1999) observed a nonlinear effect, while Viira et al. (2013) revealed that farm growth probability is highest for farmers aged 40-49 years. In terms of decline and exit, it is proved that the younger the age group, the lower the probability of the business declining and exiting the sector (Breustedt \& Glauben, 2007; Glauben et al., 2006; Viira et al., 2013), as younger farmers tend to have more capacity to grow than older farmers do (Bakucs \& Fertó, 2009). Considering portfolio entrepreneurship, Carter $(1998,2001)$ and Vesala et al. (2007) found that farmers with manifold business structures are younger than their peers. The same is found for diversification activities (García-Arias et al., 2015; Weltin et al., 2017). McElwee (2008) states in his taxonomy of entrepreneurial farmers that the type "farmer as entrepreneur" is usually younger than 45 years of age, while the "farmer as farmer" is usually older than 45 years of age and has been farming for over 20 years. In contrast, Ilbery (1991) observed that farmers with alternative enterprises are over 45 years of age, and have many years of experience.

In addition to age, education level seems to be of importance. For instance, higher entrepreneurial activity often results in an enlargement of the farm portfolio, which constitutes an increase in complexity (Carter, 1998, 2001; Gindele et al., 2015). To cope with this, many studies agree that farmers showing a high innovative entrepreneurial activity (Barbieri \& Mahoney, 2009; Carter, 1998, 2001; Gellynck et al., 2015; Vesala \& Vesala, 2010; Vesala et al., 2007) or growth activity (Bakucs \& Fertó, 2009; Rizov \& Mathijs, 2003; Viira et al., 2013) are better educated than their peers. In this context, Meert et al. (2005) regard education level as a crucial determinant of diversification. Referring to the work on drivers of organizational action by Chen (1996), it can be argued that diversification can be a function of awareness, motivation, and capability. Education may enhance awareness of possibilities as well as the capability to take action. As further aspects in this context, risktaking and creativity are regarded as favoring entrepreneurial action, especially those associated with innovation, seizing of business opportunities, and growth (European Commission [EC], 2003; Hébert \& Link, 1988; Van Praag, 1999). 
The education level can cause an ambiguous overall effect; while a higher level of education might benefit the farm development, well-educated farmers have better job opportunities outside of the farm, and this could possibly lead to a reduction in farming activities (Rizov \& Mathijs, 2003). This situation may also apply to the factor of the farmers' offfarm employment. On the one hand, an off-farm job is regarded as positive for innovation, as skills gained from an off-farm job can be applied to the family farm business and which introduces new perspectives and ideas (McFadden \& Gorman, 2016). On the other hand, an attractive job outside the farm can increase the probability that the farmer will fail to return full time to farming (Viira et al., 2013). Viewed in a different way, Weiss (1999) regards multiple job-holding as a key factor relating to the course of structural change, as it may stabilize the income and have a decelerating effect (Breustedt \& Glauben, 2007; Glauben et al., 2006; Goetz \& Debertin, 2001; Viira et al., 2013).

\subsubsection{Determinants concerning the farm}

Besides the farmers' attributes, the characteristics of the farm itself play a decisive role in determining strategic entrepreneurial choices. The size of the farm, mostly measured by the cultivated area of land, is a determinant often discussed in the literature. Accordingly, the initial size often correlates positively with the survival of the farm, that is, farm decline is more likely for smaller farms (Breustedt \& Glauben, 2007; Glauben et al., 2006; Hennessy \& Rehman, 2007; Rizov \& Mathijs, 2003; Viira et al., 2013; Weiss, 1999). Larger farms have more resources in terms of land, buildings, workforce, and financial power, which, along with managerial ability (Penrose, 1959), constitute a basis for entrepreneurial activity. This often leads to a higher tendency to think entrepreneurially and start diversification activities (Carter, 1999, 2001; García-Arias et al., 2015; Ilbery, 1991; Lange et al., 2013; McNally, 2001).

Apart from that, in some cases, diversification and pluriactivity can serve as a compensation strategy for any low profitability of bulk production due to low prices or bad production conditions (Bohnet et al., 2003; Weltin et al., 2017; Wolf et al., 2007). Therefore, these approaches can also result in a survival strategy for low-income farms, eventually leading to a new profitable source of income as an alternative form of growth (Bateman \& Ray, 1994; Bohnet et al., 2003; Meert et al., 2005; Pfeifer et al., 2009). This is in accordance with the finding of Penrose (1959) that free managerial resources due to the absence of growth possibilities in terms of land can be redeployed to start new diversification activities. In contrast to this, farmers with good conditions for classical agricultural production 
often show less entrepreneurial activity, as they do not necessarily need alternative sources of income (Grande, 2011; Ilbery, 1991; Northcote \& Alonso, 2011; Pfeifer et al., 2009). Furthermore, a number of studies found that smaller farms grow faster than larger farms (Bakucs \& Fertó, 2009; Shapiro et al., 1987; Viira et al., 2013; Weiss, 1999).

Another farm factor influencing entrepreneurship in agriculture is the farm location. Existing studies found that the proximity to big cities or areas with a high number of tourists favor diversification as well as new venture creation as sales markets and consumers are in the vicinity (Lange et al., 2013; McNally, 2001; Northcote \& Alonso, 2011; Pfeifer et al., 2009). In addition, Glauben et al. (2006) found that farms with a central location are less likely to decline and exit. In contrast to this, Goetz and Debertin (2001) detected an accelerating effect on exit rates. This may be due to the reason that especially in proximity to urban areas land prices are high (Hennig \& Latacz-Lohmann, 2017; Lehn \& Bahrs, 2018) constituting poor conditions for expansion strategies as structural decisions are considerably determined by the competitiveness of farms on the land market (Huettel \& Margarian, 2009).

\subsubsection{Determinants concerning the context}

The third field of determinants is the context of the farm and farmer. Most farms are family-run, so entrepreneurial choices are not only dependent on the business but also on the family life cycle (Alsos et al., 2014; McNally, 2001; Pfeifer et al., 2009; Viira et al., 2013). According to existing studies, the family but especially the farmer's spouse, plays a decisive supporting role in the farm strategy, especially for the emergence of new ventures (Alsos et al., 2014; Ferguson \& Hansson, 2015; McNally, 2001; Seuneke \& Bock, 2015). Family involvement in the business also has a positive effect on the decision to continue farming (Breustedt \& Glauben, 2007; Lansberg \& Astrachan, 1994; Poza, 1989) and expand the business (Weiss, 1999).

Furthermore, internal and external institutions can be identified from the literature as relevant factors affecting entrepreneurial activity. Internal institutions consist of rules evolving within a group based on experience gained over time while external institutions are imposed externally from above (Kasper \& Streit, 1998). In the agricultural setting, especially values and traditions are important internal institutions (Fitz-Koch et al., 2018) while politics, societal expectations, and technical progress all constitute external institutions influencing the agricultural sector nowadays. The pressure exerted by these actors is regarded 
as a push factor for entrepreneurship in agriculture (Burton \& Wilson, 2006; Morgan et al., 2010; Wolf et al., 2007).

Moreover, the importance of networks is widely acknowledged and subject to research within the field. Farmers are often anchored in broad social networks (Wolf, McElwee, \& Schoorlemmer, 2007) and mostly have wide networks of practise (Oreszczyn et al., 2010). This fosters new venture creation, diversification and the implementation of innovations (Ferguson \& Hansson, 2015; Grande, 2011; McFadden \& Gorman, 2016; Meert et al., 2005). Thus, networking and co-operation both constitute key entrepreneurial skills (Wolf \& Schoorlemmer, 2007).

\section{Method and data}

\subsection{Theoretical and empirical model}

The classification scheme presented in Section 2.1 assumes that the entrepreneurial activity of a farmer is the function of the farmer's choice between the different stagnation and growth strategies. The theoretical background of this choice model is based on the assumption that an individual $i$ chooses a certain strategy $s$ by comparing the utilities derived from all other alternatives $S_{i}$, and decides for the strategy maximizing their utility. This is reflected in McFadden's model of random utility maximization. Leaving out the subscript $i$ in the first two equations, the random utility of outcome $s$ can be described as

$$
U_{s}=V_{s}+\varepsilon_{s}
$$

where $V_{S}$ stands for the systematic component and $\varepsilon s$ for the random disturbance (Cramer, 2003). $V_{s}$ in this case is a function of the observed attributes of the strategic entrepreneurial choice $s$ and the characteristics of the decision-maker. The random component includes unobserved characteristics and imperfections of the alternative and the decision-maker and their individual behavior (Manski, 1977). The subscript $t$ stands for all choices. The probability $P$ that an individual makes a specific choice $s$ can be expressed as

$$
P_{s}=\operatorname{Pr}\left(U_{s}>U_{t} \text { for all } t \neq s \in S\right) \text {. }
$$

Thus, the utility associated with a particular strategy is a function of a vector containing attributes of the strategy on the one hand, and a vector of socioeconomic characteristics of the decision-maker on the other hand. This is why factors increasing the utility associated 
with a certain strategy increase a farmer's probability of choosing that strategy. In this paper, the strategies are reduction $(s=1)$, continuation $(s=2)$, expansion $(s=3)$, the dual strategy of expansion and diversification $(s=4)$, and diversification $(s=5)$.

To identify which determinants have an effect on the choice of different entrepreneurial strategies, a MNL was estimated. The decision of a farmer $i$ to choose a certain strategy $s$ is modeled as a vector yis with the decision for a certain strategy $s(i)$ equal to 1 , and all other elements equal to 0 . The probability $P$ that a farmer $i$ chooses strategy $s$ is described as a function of the investigated determinants, the covariates $x_{i}$ as well as the unknown parameters $\theta$. The probability function contains separate parameter vectors $\beta_{\mathrm{s}}^{*}$ for each state $s$. Because these vectors are expressed as a difference to another vector, a reference category $\beta_{\mathrm{t}}^{*}$ needs to be specified, which will be reduced to 0 . In this case, continuation $s=2$ is chosen as the reference category because it represents the stage in which every farmer was at least in the beginning. The formulation of the probabilities is defined as

$$
P_{i s}=P_{S}\left(x_{i}, \theta\right)=\frac{\exp \left(x_{i} \beta_{s}\right)}{1+\sum_{t \in S, t \neq 2} \exp \left(x_{i} \beta_{t}\right)}(\text { Cramer, 2003). }
$$

In this entrepreneurial choice model, factors potentially affecting the utility for the decision for a certain strategy are included as explanatory variables. In the area of farming, a similar model designed by Hennessy and Rehman (2007) has been estimated, for example, to determine the occupational choice of farm heirs.

\subsection{Data}

The data used in the study were collected by a quantitative online survey of German farmers. As the subject of the study is future-orientated, farm successors who already work on the farm and are significantly involved in the management and development of the operation were also included in the sample (37\% of the participants). This is a distinguishing feature of the sample at hand compared to census data, where only the officially-registered generation is included and some of the younger farmers are often missing. The description of the target group was: "Farmers and farm successors who already work in the farm business and are significantly involved in the management and development of the farm." To ensure that the respondent is indeed in charge of the farm business, the very first question in the survey was "Are you primarily responsible for the management and development of an agricultural business?". The participant needed to select yes, otherwise the survey re- 
spondent would not have been able to continue with the survey. The structure of the survey was organized according to the three relevant areas identified from the literature (see Section 2.2): factors concerning the farm; factors concerning the farmer; and factors concerning the context. The questions were generated according to the findings from the literature and ten expert interviews. The experts were consulted in the form of semi-structured interviews. Among the interviewees were farmers (5), agricultural economists (3), a consultant (1) and an expert of agricultural education (1).The main contributions of these interviews consisted of a discussion of the determinants derived from the literature, an adaption of these to the German context and the addition of promising relevant aspects. The survey was pre-tested twice by 26 and 19 farmers, respectively. Data collection took place from November 2018 to February 2019. The survey link and barcode were distributed through different channels: institutions, such as education centers in rural areas, farmers' and young farmers' associations' homepages, social media channels, e-mail distribution lists, and newsletters. Additionally, farmers were asked directly to take part during an agricultural fair, and flyers were distributed at further farmer events. Furthermore, articles were published in regional as well as national agricultural magazines. This resulted in 926 completed questionnaires. From these, 62 participants did not fit the target group, and were automatically led to the end of the survey. Furthermore, the variables were checked separately for big outliers, for instance, unrealistic high or low amounts of rainfall or numbers of soil quality. This led to the exclusion of 31 observations. Afterwards, every single observation was checked horizontally with regard to the consistency across the different variables. Accordingly, another 26 observations were excluded (e.g., a 25-year-old farmer who stated to work for 30 years on the farm). Finally, respondents who are just managing the farm as "external" managers without any family affiliation were omitted from the sample (62 observations) as well because the classification scheme is explicitly designed for family farmers (see Section 2.1). This led to a total of 745 respondents for the data analysis and is also the reason for the age span from 19 to 74 years as well as for the area span from 1 to 3600 ha of initial farm size.

To assign the sample to the different groups of strategic entrepreneurial choices as introduced in Section 2.1, certain characteristics of the farm and the farmer describing their entrepreneurial action during their working period on the farm were used, as illustrated in Figure 1. Assignment procedure started with the group of continuation; according to our theory, this is the state in which every farmer was, at least at the beginning. If farmers had 
decreased the amount of their owned land by at least $20 \%$, or stated that they majorly reduced the complexity of the operation, they were assigned to the first group called reduction. The change in land was measured by comparing the initial size of land owned at the point of time the farmer started farming on that farm with the current land ownership. To use the amount of land to measure farm size is a common practice (cf. e.g., Carter, 1999; Glauben et al., 2006; Huettel \& Margarian, 2009; Ilbery, 1991; Pfeifer et al., 2009; Rizov \& Mathijs, 2003; Vik \& McElwee, 2011). The threshold of $20 \%$ was set as a result of extensive discussions during the expert interviews in preparation for the survey, taking the work of Viira et al. (2013) as a starting point for discussion who used a 15\% change in standard output as threshold of growth. Apart from the change in the amount of land, all changes were coded as discrete variables. Farmers who increased their land ownership by at least $20 \%$ or expanded animal husbandry or other activities implemented by their predecessors were assigned to the third group labeled expansion. It is worth noting that intergenerational succession is implied by the term "predecessor." Furthermore, farmers who started diversification activities by themselves were assigned to the group diversification. These activities include the cultivation of unconventional crops, keeping of unconventional animal breeds, pursuing activities in the area of forestry, practicing agricultural contraction and wage services, offering overnight accommodation, performing leisure activities, using alternative marketing and distribution channels, processing agricultural products, and performing solidary, social, or educational activities. A relevant question was included in the survey to identify both the farmers who started these activities by themselves and those who just continued or expanded their predecessor's diversification activities. According to the aforementioned criteria, the sample revealed that most farmers who started diversification activities by themselves also expanded existing agricultural or diversification activities. Finally, another group of a dual strategy was created. These farmers were assigned to the group expansion and diversification. The frequency distribution within the different groups of the dependent variable is described in Table 1.

Table 1. Frequency distribution of the dependent variable

\begin{tabular}{l|l|l}
\hline Strategic entrepreneurial choice & Number of observations & Frequency $\mathbf{( \% )}$ \\
\hline Reduction $=1$ & 52 & 6.98 \\
Continuation $=2$ & 124 & 16.64 \\
Expansion = 3 & 377 & 50.60 \\
Expansion \& Diversification $=4$ & 150 & 20.13 \\
Diversification = 5 & 42 & 5.64 \\
\hline Total & 745 & 100.00 \\
\hline
\end{tabular}


As the survey covered a wide range of variables and was constructed according to the existing literature, most of the factors hypothesized to influence the strategic entrepreneurial choice of a farmer can be specified. The descriptive statistics of the independent variables are presented in Table 2.

Table 2. Descriptive statistics of the independent variables

\begin{tabular}{|c|c|c|c|c|c|c|}
\hline Variable & Definition & Scale/measurement & Mean & SE & Min & Max \\
\hline \multicolumn{7}{|c|}{ Personal factors } \\
\hline Male & Gender & $1=$ male $0=$ female & 0.85 & 0.01 & 0 & 1 \\
\hline Age & Age & number of years & 38.37 & 0.47 & 19 & 74 \\
\hline Degree & $\begin{array}{l}\text { Third-level education; degree } \\
\text { from a university or university } \\
\text { of applied sciences }\end{array}$ & $1=$ yes $; 0=$ no & 0.39 & 0.02 & 0 & 1 \\
\hline Job & Off-farm job of the farmer & $1=$ yes $; 0=$ no & 0.31 & 0.02 & 0 & 1 \\
\hline Creativity & $\begin{array}{l}\text { Creativity according to Nan- } \\
\text { dram and Samson }(2000) \text { and } \\
\text { Lauwere }(2005) \text {, average index } \\
\text { (C.A. }=0,8276)\end{array}$ & $\begin{array}{l}1=\text { do not agree at all; } 7=\text { totally } \\
\text { agree }\end{array}$ & 5.66 & 0.03 & 1 & 7 \\
\hline Risk & $\begin{array}{l}\text { Risk attitude via subjective self- } \\
\text { assessment according to } \\
\text { Dohmen et al. (2011) }\end{array}$ & $\begin{array}{l}0=\text { not at all willing to take risks; } \\
10=\text { very willing to take risks }\end{array}$ & 6.02 & 0.07 & 0 & 10 \\
\hline \multicolumn{7}{|l|}{ Farm factors } \\
\hline Size & $\begin{array}{l}\text { Initial farm size, total area } \\
\text { under cultivation in hectares }\end{array}$ & number of hectares & 167.2 & 12.48 & 1 & 3600 \\
\hline Soil & $\begin{array}{l}\text { Average soil quality on the } \\
\text { agricultural main site according } \\
\text { to the German system of } \\
\text { "Ackerzahl" }\end{array}$ & points $1-100$ & 47.61 & 0.65 & 12 & 100 \\
\hline Rain & $\begin{array}{l}\text { Average rainfall on the agricul- } \\
\text { tural main site in } \mathrm{mm} / \text { year }\end{array}$ & number $\mathrm{mm} /$ year & 709.45 & 6.75 & 250 & 1500 \\
\hline West & $\begin{array}{l}\text { Location of agricultural sites in } \\
\text { the old German states }\end{array}$ & $1=$ yes $; 0=$ no & 0.90 & 0.01 & 0 & 1 \\
\hline Central & $\begin{array}{l}\text { Location of the agricultural } \\
\text { main site near a metropolitan } \\
\text { area or tourist / recreation re- } \\
\text { gion }\end{array}$ & $1=$ yes $; 0=$ no & 0.10 & 0.01 & 0 & 1 \\
\hline \multicolumn{7}{|c|}{ Context factors } \\
\hline WF_family & $\begin{array}{l}\text { Number of family workers in } \\
\text { the business }\end{array}$ & number of family workers & 2.00 & 0.04 & 0 & 6 \\
\hline WF_spouse & $\begin{array}{l}\text { Spouse works / assists on the } \\
\text { farm / in the business }\end{array}$ & $1=$ yes $; 0=$ no & 0.37 & 0.02 & 0 & 1 \\
\hline An_values & $\begin{array}{l}\text { Strength of anchoring of the } \\
\text { farm manager and their actions } \\
\text { in basic Christian values }\end{array}$ & $1=$ not strong at all; $7=$ very strong & 4.08 & 0.07 & 1 & 7 \\
\hline An_tradition & $\begin{array}{l}\text { Strength of anchoring of the } \\
\text { farm manager and their actions } \\
\text { in farming tradition }\end{array}$ & $1=$ not strong at all $; 7=$ very strong & 4.38 & 0.06 & 1 & 7 \\
\hline Pr_politics & $\begin{array}{l}\text { Political/legal pressure (per- } \\
\text { ceived) on the farmer and the } \\
\text { operation }\end{array}$ & $1=$ not strong at all; $7=$ very strong & 6.08 & 0.04 & 1 & 7 \\
\hline Pr_society & $\begin{array}{l}\text { Societal pressure (perceived) on } \\
\text { the farmer and the operation }\end{array}$ & $1=$ not strong at all; $7=$ very strong & 5.61 & 0.05 & 1 & 7 \\
\hline Pr_progress & $\begin{array}{l}\text { Technical progress and growth } \\
\text { pressure (perceived) on the } \\
\text { farmer and the operation }\end{array}$ & $1=$ not strong at all; $7=$ very strong & 4.63 & 0.05 & 1 & 7 \\
\hline Coop & Cooperation with other farmers & $1=$ yes $; 0=$ no & 0.77 & 0.02 & 0 & 1 \\
\hline
\end{tabular}

Note: Translated from German to English; $\mathrm{SE}=$ Standard Error

The effects of personal factors are tested using the gender, age, and education level, in terms of the presence of a third-level education of the farmer. Only 10\% of German farms are managed by women (DBV, 2018), which leads to the conclusion that men are relatively 
underrepresented in the data - men in the sample have a share of $85 \%$. The average age of the farmers in the data is 38 years, which is younger than the German average, given that $34 \%$ of all farmers are older than 55 years of age (DBV, 2018). This can be explained by the inclusion of the younger generation in the sample of the study. Of the respondents, $39 \%$ hold a degree from a university or a university of applied sciences, and clearly had a higher level of education than average German farmers do (12\%) (DBV, 2018). This may be caused by greater open-mindedness for research topics among farmers with third-level education. Creativity was surveyed by calculating the average index of certain items according to Nandram and Samson (2000) and Lauwere (2005) and resulted in a mean of 5.66 on a 7-point Likert scale from 1 (do not agree at all) to 7 (totally agree). The risk attitude was measured according to Dohmen et al. (2011), and resulted in an average of 6.02 on an 11-point scale from 0 (not at all willing to take risks) to 10 (very willing to take risks), indicating a slight risk affinity (the scales can be found in the Appendix). Furthermore, the farmers were asked if they had an off-farm occupation besides the farming business.

To test the effects of farm characteristics, farm size, and location factors were used. To avoid endogeneity, and keeping in line with other studies, the size was measured by the total area under cultivation at the point in time when the respondent started working on the farm. This was done to determine the effect of the precondition of the initial farm size on the entrepreneurial activity of the farmer. The rather high initial average amount of land of 167 ha (actual amount of 231 ha) compared with the German average of 62 ha in 2017 (DBV, 2018) may be caused primarily by a high share of full-time farms in the sample $(86 \%)$. The location factors were divided into soil quality and the amount of rainfall, prerequisites for agricultural production, and the geographical location was represented by the proximity to a metropolitan area or tourist and recreational region. As the structures of farms in Germany still differ significantly between the western and eastern regions due to the historical division of Germany, the geographical location of the farm in the western or eastern federal states was tested as a possible determinant as well.

The contextual effects were tested using family involvement in the operation by the number of family workers and the spouse's contribution to the business. The influence of internal institutions was measured by the anchoring of the farmer in values and traditions and external institutions by the perceived pressure of politics, society, and technical progress. 
As networking and co-operation were mentioned in earlier studies, a variable indicating whether the farmer co-operates with others was included as well.

To test for multicollinearity, the variance inflation factors were calculated for the independent variables. With a mean of 1.23 and a range between 1.04 and 1.64, the numbers are far below the threshold level of 10. This indicates that multicollinearity is not a severe issue in the regression at hand. Correlation analysis confirmed this result (see Appendix B). To ensure that the independence of irrelevant alternatives assumption (IIA) as a prerequisite for the MNL holds, a Hausman test was performed. MNL is the appropriate model for the data at hand.

\section{$4 \quad$ Results and discussion}

The results of the MNL investigating the effects of different determinants on strategic entrepreneurial choices in agriculture are presented in Table 3. Some independent variables from Table 2 have been excluded from the model because the Wald test of significance could not be rejected, meaning that the excluded variables have no significant influence on the choice of the different strategies. These variables include gender as well as the proxies for internal and external institutions. Co-operation with other farmers was also shown to have no significant effect.

Table 3. Effects of factors on different strategic entrepreneurial choices in agriculture

\begin{tabular}{|c|c|c|c|c|c|c|c|c|}
\hline \multirow[b]{2}{*}{ Variable } & \multicolumn{2}{|c|}{$\begin{array}{r}\text { Reduction } \\
\qquad S=1\end{array}$} & \multicolumn{2}{|c|}{$\begin{array}{r}\text { Expansion } \\
s=3\end{array}$} & \multicolumn{2}{|c|}{$\begin{array}{c}\text { Expansion \& Div. } \\
s=4\end{array}$} & \multicolumn{2}{|c|}{$\begin{array}{c}\text { Diversification } \\
\quad s=5\end{array}$} \\
\hline & Coeff. & SE & Coeff. & SE & Coeff. & SE & Coeff. & SE \\
\hline \multicolumn{9}{|c|}{ Personal factors } \\
\hline Age & 0.126 **** & 0.019 & $0.068 * * *$ & 0.013 & $0.110 * * *$ & 0.015 & $0.063^{* * *} *$ & 0.019 \\
\hline Degree & 0.305 & 0.382 & $-0.437 *$ & 0.233 & -0.161 & 0.294 & 0.423 & 0.386 \\
\hline Job & $1.642 * * *$ & 0.399 & 0.161 & 0.245 & -0.079 & 0.314 & -0.255 & 0.424 \\
\hline Creativity & 0.165 & 0.247 & -0.017 & 0.156 & $0.649 * * *$ & 0.203 & $0.655^{* *}$ & 0.280 \\
\hline Risk & $-0.169 *$ & 0.101 & 0.075 & 0.062 & $\mathbf{0 . 2 5 5}$ *** & 0.079 & 0.041 & 0.100 \\
\hline \multicolumn{9}{|l|}{ Farm factors } \\
\hline Size & $-0.003 *$ & 0.002 & $-0.001 * *$ & 0.000 & $-0.001 * *$ & 0.001 & -0.002 & 0.001 \\
\hline Soil & -0.008 & 0.010 & $-0.011 *$ & 0.006 & $-0.017 * *$ & 0.008 & 0.004 & 0.010 \\
\hline Rain & -0.000 & 0.001 & $0.001 *$ & 0.001 & $0.002 * *$ & 0.001 & 0.001 & 0.001 \\
\hline Central & $-1.156 *$ & 0.681 & $-0.769 * *$ & 0.344 & -0.116 & 0.415 & 0.311 & 0.489 \\
\hline \multicolumn{9}{|c|}{ Context factors } \\
\hline WF_family & -0.065 & 0.209 & $0.308 * * *$ & 0.114 & 0.055 & 0.143 & 0.224 & 0.186 \\
\hline WF_spouse & 0.118 & 0.432 & 0.251 & 0.288 & $0.905^{* * *}$ & 0.331 & 0.627 & 0.436 \\
\hline
\end{tabular}

Notes: $\mathrm{N}=745$; Prob > chi2 $=0.0000 ;$ Pseudo $\mathrm{R}^{2}=0.1536$; Log likelihood $=-828.42911$

Percentage of correct predictions: total: $40 \%, \mathrm{~s}=1: 62 \%, \mathrm{~s}=2: 55 \%, \mathrm{~s}=3: 30 \%, \mathrm{~s}=4: 50 \%, \mathrm{~s}=5: 24 \%$.

$* \mathrm{p}<0.1 ; * * \mathrm{p}<0.05 ; * * * \mathrm{p}<0.01 ; \mathrm{SE}=$ Standard Error

The model is significant at the $1 \%$ level. The results of a confusion matrix reveal that $40 \%$ of the total observations were correctly predicted. This differs between categories and is a widely known issue in a study of this kind. An explanation for this is that the prediction 
accuracy is sensitive to the number of outcome categories. The predictive power of a model suffers from a large number of categories (Cramer, 2003). By combining groups $s=1$ and $\mathrm{s}=2$ or $\mathrm{s}=4$ and $\mathrm{s}=5$, the prediction accuracy improves slightly, but the other goodness-of-fit measures as well as the informative value of the model concerning the choice of a certain strategy decrease, therefore the five categories are maintained.

\subsection{Determinants concerning the farmer}

Regarding the results of the personal factors, the factor age significantly increases the likelihood of all strategies, meaning that the older the farmers are, the more likely they are to choose a strategy other than continuing their predecessor's activities. This effect may stem from the fact that older farmers have had more time to potentially change their business structures and demonstrate more entrepreneurial activity than younger farmers, who are new to the business. This is also in line with Ilbery (1991) who shows that farmers with alternative enterprises are often not young and new entrants to the business, rather they are older and more experienced farmers.

In terms of the education level, a farmer holding a third-level qualification is significantly less likely to expand on existing activities. This is in contrast to the agricultural growth literature (Bakucs \& Fertó, 2009; Rizov \& Mathijs, 2003; Viira et al., 2013). In opposition to the findings from the literature that the new perspectives and ideas gained in an off-farm job may encourage diversification activities (McFadden \& Gorman, 2016) the results reveal that farmers holding a job outside the farm are more likely to follow a reduction strategy. This might be explained by the limited time and entrepreneurial resources available for their own businesses, and the attraction of the stable income offered by an off-farm job (Breustedt \& Glauben, 2007; Glauben et al., 2006; Goetz \& Debertin, 2001; Penrose, 1959; Viira et al., 2013).

In terms of creativity, a high expression significantly fosters diversification activities, with or without the expansion of existing activities. Furthermore, farmers with a high risk affinity are significantly more likely to choose a dual strategy of expansion and diversification and significantly less likely to follow a reduction strategy. These findings are in line with the entrepreneurship literature (EC, 2003; Hébert \& Link, 1988; Van Praag, 1999). 


\subsection{Determinants concerning the farm}

Results reveal that the larger the initial farm size, the less likely it is that farmers from this sample choose a reduction strategy. Furthermore, the larger the initial farm size, the less likely they are to pursue a dual strategy of expansion and diversification. This supports the findings from the literature that diversification can serve as a survival strategy (Bateman $\&$ Ray, 1994; Bohnet et al., 2003; Brandth \& Haugen, 2011; Meert et al., 2005; Pfeifer et al., 2009) and compensation for low profits from certain agricultural production (Bohnet et al., 2003; Weltin et al., 2017; Wolf et al., 2007). Finally, smaller farms may find niches and alternative sources of income within the diversification approach next to the expansion of existing activities (Grande, 2011; Ilbery, 1991; Northcote \& Alonso, 2011; Pfeifer et al., 2009). At the same time, the probability of choosing an expansion strategy instead of continuing with what the predecessor has started decreases with a larger initial farm size. This might be explained by the fact that the necessity of an expansion is lower when the farm disposes over a large amount of land already. Other studies found accordingly that smaller farms grow faster than larger farms do (Bakucs \& Fertó, 2009; Shapiro et al., 1987; Viira et al., 2013; Weiss, 1999).

The soil quality and amount of rainfall, as natural conditions for agricultural production, reveal contrasting significant results for the expansion and dual strategies. While a better soil quality implies a lower probability of being in one of these two groups, a higher amount of rainfall implies a higher probability. The results concerning soil quality support the findings from the literature that farmers with good conditions for classic agricultural production often show less entrepreneurial growth activity, as they do not necessarily need alternative sources of income, and, thus, continue doing what has always been done (Grande, 2011; Ilbery, 1991; Northcote \& Alonso, 2011; Pfeifer et al., 2009).

When the farm is situated at a central location, (i.e. defined as the proximity to big cities or tourist areas), it has a significantly negative effect on expansion strategies. This may be due to the fact that land prices are high around urban areas (Hennig \& Latacz-Lohmann, 2017; Lehn \& Bahrs, 2018) and expansion activities usually require space and remote surroundings. At the same time, a central location decreases the probability of pursuing a reduction strategy. 


\subsection{Determinants concerning the context}

Regarding the context of the farm, only the involvement of the family, in particular of the spouse, proved to be significant. The findings show that the more family members working on the farm, the significantly higher the probability of choosing an expansion strategy. This is in line with the literature stating that family involvement in the business supports the decision to continue farming (Breustedt \& Glauben, 2007; Lansberg \& Astrachan, 1994; Poza, 1989) and to expand the business (Weiss, 1999). The spouse's involvement proves to have a supporting influence on the dual strategy of expansion and diversification. This may stem from the fact that the spouse, who is most likely a woman as most farms are run by men (85\%), are more likely to start new ventures (Barbieri \& Mahoney, 2009; Bock, 2004; McGehee \& Kim, 2004; McGehee et al., 2007; Seuneke \& Bock, 2015). Women often play an active role in initiating diversification activities (Barbieri \& Mahoney, 2009; Bock, 2004), while men are mostly regarded as being growth-oriented (Bakucs \& Fertó, 2009; Cliff, 1998; Pindado \& Sánchez, 2018; Weiss, 1999). Therefore, the involvement of both partners in the business may lead to a dual strategy.

Table 4. Marginal effects of factors on the strategic entrepreneurial choices in agriculture

\begin{tabular}{|c|c|c|c|c|c|}
\hline Variable & $\begin{array}{c}\text { Reduction } \\
\mathrm{s}=1\end{array}$ & $\begin{array}{c}\text { Continuation } \\
\mathrm{s}=\mathbf{2} \\
\end{array}$ & $\begin{array}{c}\text { Expansion } \\
\mathbf{s}=\mathbf{3}\end{array}$ & $\begin{array}{c}\begin{array}{c}\text { Expansion \& Div. } \\
\mathrm{s}=\mathbf{4}\end{array} \\
\end{array}$ & $\begin{array}{c}\text { Diversification } \\
\mathrm{S}=\mathbf{5} \\
\end{array}$ \\
\hline \multicolumn{6}{|c|}{ Personal factors } \\
\hline Age & 0.0021 & -0.0088 & -0.0002 & 0.0071 & -0.0003 \\
\hline Degree & 0.0225 & 0.0324 & -0.1115 & 0.0148 & 0.0418 \\
\hline Job & 0.0815 & -0.0199 & -0.0003 & -0.0393 & -0.0220 \\
\hline Creativity & 0.0007 & -0.0188 & -0.0982 & 0.0869 & 0.0293 \\
\hline Risk & -0.0098 & -0.0109 & -0.0061 & 0.0294 & -0.0026 \\
\hline \multicolumn{6}{|l|}{ Farm factors } \\
\hline Size & -0.0001 & 0.0001 & 0.0001 & -0.0001 & -0.0000 \\
\hline Soil & 0.0000 & 0.0013 & -0.0010 & -0.0012 & 0.0008 \\
\hline Rain & -0.0000 & -0.0002 & 0.0001 & 0.0001 & -0.0000 \\
\hline Central & -0.0209 & 0.0682 & -0.1713 & 0.0645 & 0.0596 \\
\hline \multicolumn{6}{|c|}{ Context factors } \\
\hline WF_family & -0.0104 & -0.0264 & 0.0617 & -0.0260 & 0.0011 \\
\hline WF_spouse & -0.0089 & -0.0439 & -0.0644 & 0.1015 & 0.0158 \\
\hline
\end{tabular}

The results of the MNL are presented as marginal effects in Table 4. Marginal effects describe the probability of change of a dependent variable given a one-unit change of an independent variable, all else being equal. This type of presentation illustrates, for example, the discussed strong influence of the spouse's involvement in the business on the dual strategy of expansion and diversification. If the spouse works in the business, the probability of choosing a dual strategy increases by $10.15 \%$, other things being equal. Another strong factor is the influence of creativity on diversification; with every additional creativi- 
ty point on the Likert scale, the probability of following a diversification strategy increases by $2.93 \%$, and that for a dual strategy increases by $8.69 \%$.

\subsection{Limitations and further research}

Some limitations of the present study should be kept in mind when interpreting the results. First, comparability with representative national data is restricted, especially since the sample included the young generation of farmers. The paper does not claim generalizability, despite the study being relatively extensive with a sample size of $\mathrm{N}=745$. However, generalizability could be improved, particularly with regard to the distribution of educational attainment and farm size. Furthermore, regarding the factor age, the results intuitively reveal that the longer a person works within the business, the more time they have to act, and thus to change to another group other than continuation. As successors are also included within the sample, it can be argued that these participants did not have enough time to act, and are therefore stuck within the group of continuation. Still, taking a closer look at the percentage of successors within the group of continuation, only $27 \%$ of the successors belong to this group. The other $73 \%$ has indeed changed strategy.

In addition, a general classification scheme for entrepreneurial activity in agriculture was derived from the literature. On this basis, a regression analysis in the form of a MNL model was conducted for the collected data. While this ensures broad applicability and comparability to other samples and regions, a clustering approach could allow more specific classifications. In further investigations, comparisons between the classification scheme derived from the literature and that derived from the results of a cluster analysis could be an interesting topic. An advantage of the use of this classification scheme, and another point for future research, is that it could also be applied to other countries and econometrically tested to compare and assess different systems and framework conditions influencing the determinants of strategic entrepreneurial choices in agriculture.

Moreover, to measure aspects like risk or creativity, self-reported scales were used. These are supported by previous studies, but still imply the risk of social desirability and subjective responses. Lastly, norms and values were mentioned in the entrepreneurship literature as further influential factors. Within our study, these constructs did not reveal significant results. However, as these are abstract phenomena that are hard to capture within a study like this, further research with different approaches could be done in this area. 


\section{$5 \quad$ Summary and implications}

Entrepreneurship in agriculture is a phenomenon that is growing and becoming of greater importance with the changing framework conditions for agricultural production and increasing structural change. It leads to heterogeneity in farm business development paths. To understand this phenomenon better, and derive implications for farmers, agricultural consultants, and policymakers, a classification scheme of strategic entrepreneurial choices in agriculture is developed. These strategic entrepreneurial choices of family farmers are reduction, continuation, expansion, diversification, and the dual strategy of expansion and diversification. The classification scheme and the determinants of the respective entrepreneurial choices are investigated empirically by applying a MNL to a survey conducted Germany-wide among farmers $(\mathrm{N}=745)$ from November 2018 to February 2019.

Among the factors concerning the farmer, important determinants of entrepreneurship are creativity and the risk attitude of the farmer. According to the present results, increasing the expression of a farmer's creativity may lead to more diverse business strategies. Furthermore, the results show that a higher affinity toward risk can increase the likelihood to follow the entrepreneurial strategy of expansion and diversification and lower the likelihood to follow a reduction strategy, instead of just continuing with what the predecessor has already implemented. Therefore, to create room for more diverse business strategies, farmers should be offered the opportunity to test and implement creative ideas under real, uncertain conditions. This could be in the form of creative training, the formation of working groups to exchange ideas and motivate each other, or the provision of financial support for realizing those new projects. Furthermore, the concepts of risk and creativity should be taught in the early years of agricultural training programs, to foster the respective selfawareness and understanding of future agricultural entrepreneurs. Farmers themselves should seek to actively participate in such programs as early within their tenure as possible, to be better equipped to identify promising diversification strategies and, if those are assessed as economically worthwhile, to consequently implement them. At the same time, they should encourage their potential successors to also participate in such programs and include them early in actual strategic entrepreneurial decisions which require taking risk and being creative.

Regarding the farm characteristics, the initial farm size with which the farmers started their tenure and its proximity to urban areas seem to play especially a big role. Looking at the initial farm size, the results suggest that smaller farms are generally more likely to engage 
in a dual strategy of expansion and diversification. Especially farmers with a relatively small resource endowment (e.g. arable land) can learn from this to continuously analyze their long-term market position and viability as early as possible and, based on this, consider potential promising diversification activities. From a policy perspective, smaller farmers should especially receive further support to increase diversification activities and thus become more entrepreneurial. Moreover, a central location of the farm, its vicinity to cities or tourist areas, is likely to hinder expansion activities. Thus, both smaller farms and farmers in a central location without the possibility to expand the conventional way should be supported to develop alternative strategies to sustain themselves. Additionally, those programs need to be location-specific. This is where start-up activities come into play. Platforms may be established to build an inter-sectorial exchange. Start-up funding and extension services may also enhance these developments.

The strongest effects among the context factors are the involvement of not only family, but especially the spouse. Every additional family member involved in the business has an accelerating effect on an expansion strategy. It is striking that the active co-operation of a spouse within the business can have accelerating effects for the uptake of a dual strategy of expansion and diversification. From the perspective of farmers, this indicates that the involvement of their family members and especially spouses can have long-term stabilizing and enhancing effects on their businesses. From the perspective of policymakers, conditions should be created so that many family members, particularly the spouse, can have the opportunity to work in the business. As agriculture is currently dominated by men who are partnered with women, most spouses are women. The results support the theory that women play key roles in diversification activities and, thus, may function as important innovators in this field; they should also be supported.

\section{CRediT authorship contribution statement}

Viktoria Graskemper: Conceptualization, Investigation, Data Curation, Methodology, Software, Formal analysis, Writing - Original Draft, Visualization. Xiaohua Yu: Methodology, Validation. Jan-Henning Feil: Conceptualization, Writing - review \& editing, Supervision. 
III Analyzing strategic entrepreneurial choices in agriculture - Empirical evidence from Germany

\section{Acknowledgements}

We would like to thank Andreas Quiring of the Andreas Hermes Akademie and Markus Fahlbusch for their valuable comments. We gratefully acknowledge financial support from the German Research Foundation (DFG).

\section{Conflict of interests}

The authors declare that there are no conflicts of interests.

\section{Data availability statement}

The data that support the findings of this study are available from the corresponding author upon reasonable request.

\section{ORCID}

Viktoria Graskemper http://orcid.org/0000-0001-7117-5738

Xiaohua Yu http://orcid.org/0000-0003-4257-8081

Jan-Henning Feil http://orcid.org/0000-0001-5958-5822 


\section{References}

Alsos, G. A., Carter, S., \& Ljunggren, E. (2014). Kinship and Business: How Entrepreneurial Households Facilitate Business Growth. Entrepreneurship \& Regional Development, 26(1-2), 97-122. https://doi.org/10.1080/08985626.2013.870235

Appel, F., \& Balmann, A. (2018). Human behaviour versus optimising agents and the resilience of farms - Insights from agent-based participatory experiments with FarmAgriPoliS. Ecological Complexity. Advance online publication. https:// doi.org/10.1016/j.ecocom.2018.08.005

Bakucs, L. Z., \& Fertó, I. (2009). The growth of family farms in Hungary. Agricultural Economics, 40(3), 789-795. https://doi.org/10.1111/j.1574-0862.2009.00415.x

Barbieri, C., \& Mahoney, E. (2009). Why is diversification an attractive farm adjustment strategy? Insights from Texas farmers and ranchers. Journal of Rural Studies, 25(1), 5866. https://doi.org/10.1016/j.jrurstud.2008.06.001

Bateman, D., \& Ray, C. (1994). Farm pluriactivity and rural policy: Some evidence from Wales. Journal of Rural Studies, 10(1), 1-13. https://doi.org/10.1016/07430167(94)90002-7

Bock, B. B. (2004). Fitting in and multi-tasking: Dutch farm women's strategies in rural entrepreneurship. Sociologia Ruralis, 44(3), 245-260. https://doi.org/10.1111/j.14679523.2004.00274.x

Bohnet, I., Potter, C., \& Simmons, E. (2003). Landscape change in the multi-functional countryside: A biographical analysis of farmer decision-making in the English high weald. Landscape 28(4), 349-364. https://doi.org/10.1080/0142639032000150112

Bowler, I. R. (1992). 'Sustainable Agriculture' as an alternative path of farm business development. In I. R. Bowler, C. R. Bryant, \& M. D. Nellis (Eds.), Contemporary rural systems in transition: Agriculture and environment (Vol. 1, pp. 237-253). Wallingford.

Brandth, B., \& Haugen, M. S. (2011). Farm diversification into tourism - Implications for social identity? Journal of Rural Studies, 27(1), 35-44. https://doi.org/10.1016/j.jrurstud.2010.09.002 
Breustedt, G., \& Glauben, T. (2007). Driving forces behind exiting from farming in Western Europe. Journal of Agricultural Economics, 58(1), 115-127. https://doi.org/10.1111/j.1477-9552.2007.00082.x

Burton, R. J. F., \& Wilson, G. A. (2006). Injecting social psychology theory into conceptualisations of agricultural agency: Towards a post-productivist farmer self-identity? Journal of Rural Studies, 22(1), 95-115. https://doi.org/10.1016/j.jrurstud.2005.07.004

Carter, S. (1998). Portfolio entrepreneurship in the farm sector: Indigenous growth in rural areas? Entrepreneurship \& Regional Development, 10(1), 17-32. https://doi.org/10.1080/08985629800000002

Carter, S. (1999). Multiple business ownership in the farm sector: Assessing the enterprise and employment contributions of farmers in Cambridgeshire. Journal of Rural Studies, 15(4), 417-429. https://doi.org/10.1016/S0743-0167(99)00004-2

Carter, S. (2001). Multiple business ownership in the farm sector-Differentiating monoactive, diversified and portfolio enterprises. International Journal of Entrepreneurial Behavior \& Research, 7(2), 43-59. https://doi.org/10.1108/13552550110695552

Chen, M.-J. (1996). Competitor analysis and interfirm rivalry: Toward a theoretical integration. The Academy of Management Review, 21(1), 100-134. https://doi.org/10.2307/258631

Cliff, J. E. (1998). Does one size fit all? Exploring The relationship between attitudes towards growth, gender, and business size. Journal of Business Venturing, 13(6), 523542. https://doi.org/10.1016/S0883-9026(97)00071-2

Cramer, J. S. (2003). Logit models: From economics and other fields. Cambridge University Press. https://doi.org/10.1017/CBO9780511615412

Deutscher Bauernverband (DBV). (2018). Situationsbericht 2018/19: Trends und Fakten zur Landwirtschaft. Berlin.

Dias, C. S. L., Rodrigues, R. G., \& Ferreira, J. J. (2019a). Agricultural entrepreneurship: Going back to the basics. Journal of Rural Studies. Advance online publication. https://doi.org/10.1016/j.jrurstud.2019.06.001

Dias, C. S. L., Rodrigues, R. G., \& Ferreira, J. J. (2019b). What's new in the research on agricultural entrepreneurship? Journal of Rural Studies, 65, 99-115. https://doi.org/10.1016/j.jrurstud.2018.11.003 
Dohmen, T., Falk, A., Huffman, D., Sunde, U., Schupp, J., \& Wagner, G. G. (2011). Individual risk attitudes: Measurement, determinants, and behavioral consequences. Journal of the European Economic Association, 9(3), 522-550. https://doi.org/10.1111/j.15424774.2011.01015.x

European Commission (EC) (2003, January 21). Green Paper: Entrepreneurship in Europe (No. $\operatorname{COM}(2003) \quad 27$ final). Brussels. http://ec.europa.eu/invest-inresearch/pdf/download_en/entrepreneurship_europe.pdf

Ferguson, R., \& Hansson, H. (2015). Measuring embeddedness and its effect on new venture creation - A study of farm diversification. Managerial and Decision Economics, 36(5), 314-325. https://doi.org/10.1002/mde.2671

Fitz-Koch, S., Nordqvist, M., Carter, S., \& Hunter, E. (2018). Entrepreneurship in the agricultural sector: A literature review and future research opportunities. Entrepreneurship Theory and Practice, 42(1), 129-166. https://doi.org/10.1177/1042258717732958

García-Arias, A.-I., Vázquez-González, I., Sineiro-García, F., \& Pérez-Fra, M. (2015). Farm diversification strategies in northwestern Spain: Factors affecting transitional $\begin{array}{llll}\text { pathways. } & \text { Land } & \text { Use } & \text { 413-425. }\end{array}$ https://doi.org/10.1016/j.landusepol.2015.08.011

Gellynck, X., Cárdenas, J., Pieniak, Z., \& Verbeke, W. (2015). Association between innovative entrepreneurial orientation, absorptive capacity, and farm business performance. Agribusiness, 31(1), 91-106. https://doi.org/10.1002/agr.21394

Gindele, N., Kaps, S., \& Doluschitz, R. (2015). Strukturelle Veränderungen in der Landwirtschaft - Reaktion der landwirtschaftlichen Betriebsleiter sowie ableitbare Konsequenzen für den Landwirt als Unternehmer. Journal of Socio-Economics in Agriculture, $8,11-20$.

Glauben, T., Tietje, H., \& Weiss, C. (2006). Agriculture on the move: Exploring regional differences in farm exit rates in Western Germany. Jahrbuch für Regionalwissenschaft, 26(1), 103-118. https://doi.org/10.1007/s10037-004-0062-1

Goetz, S. J., \& Debertin, D. L. (2001). Why farmers quit: A county-level analysis. American Journal of Agricultural Economics, 83(4), 1010-1023. https://doi.org/10.1111/0002-9092.00226 
Grande, J. (2011). New venture creation in the farm sector - Critical resources and capabil$\begin{array}{llll}\text { ities. Journal } & \text { of } & \text { Rural 220-233. }\end{array}$ https://doi.org/10.1016/j.jrurstud.2011.02.003

Grethe, H., Arens-Azevedo, U., Balmann, A., Biesalski, H. K., Birner, R., Bokelmann, W., \& Weingarten, P. (2018). Für eine gemeinwohlorientierte Gemeinsame Agrarpolitik der EU nach 2020: Grundsatzfragen und Empfehlungen. Berichte über Landwirtschaft, Advance online publication https://doi.org/10.12767/BUEL.V0I225

Hennessy, T. C., \& Rehman, T. (2007). An investigation into factors affecting the occupational choices of nominated farm heirs in Ireland. Journal of Agricultural Economics, 58(1), 61-75. https://doi.org/10.1111/j.1477-9552.2007.00078.x

Hennig, S., \& Latacz-Lohmann, U. (2017). The incidence of biogas feed-in tariffs on farmland rental rates - evidence from northern Germany. European Review of Agricultural Economics, 44(5), 781. https://doi.org/10.1093/erae/jbx012

Huettel, S., \& Margarian, A. (2009). Structural change in the West German agricultural sector. Agricultural Economics, 40, 759-772. https://doi.org/10.1111/j.15740862.2009.00413.x

Hébert, R. F., \& Link, A. N. (1988). The entrepreneur: Mainstream views \& radical critiques (2nd ed.). Praeger.

Ilbery, B. W. (1991). Farm diversification as an adjustment strategy on the urban fringe of the West Midlands. Journal of Rural Studies, 7(3), 207-218. https://doi.org/10.1016/0743-0167(91)90085-7

Ilbery, B. W., \& Bowler, I. R. (1998). From agricultural productivism to postproductivism. In B. W. Ilbery (Ed.), The geography of rural change (pp. 57-84). Harolw, UK: Longman.

Kasper, W., \& Streit, M. (1998). Institutional economics: Social order and public policy. Edward Elger.

Lange, A., Piorr, A., Siebert, R., \& Zasada, I. (2013). Spatial differentiation of farm diversification: How rural attractiveness and vicinity to cities determine farm households' response to the CAP. Land Use Policy, 31, 136-144. https://doi.org/10.1016/j.landusepol.2012.02.010 
Lansberg, I., \& Astrachan, J. H. (1994). Influence of family relationships on succession planning and training: The importance of mediating factors. Family Business Review, 7(1), 39-59. https://doi.org/10.1111/j.1741-6248.1994.00039.x

de Lauwere, C.C. (2005). The role of agricultural entrepreneurship in Dutch agriculture of today. Agricultural Economics, 33(2), 229-238. https://doi.org/10.1111/j.15740862.2005.00373.x

Lehn, F., \& Bahrs, E. (2018). Analysis of factors influencing standard farmland values with regard to stronger interventions in the German farmland market. Land Use Policy, 73, 138-146. https://doi.org/10.1016/j.landusepol.2018.01.020

Manski, C. F. (1977). The structure of random utility models. Theory and Decision, 8(3), 229-254. https://doi.org/10.1007/BF00133443

McElwee, G. (2006). Farmers as entrepreneurs: Developing competitive skills. Journal of Developmental Entrepreneurship, $11(03)$ 187-206. https://doi.org/10.1142/S1084946706000398

McElwee, G. (2008). A taxonomy of entrepreneurial farmers. International Journal of Entrepreneurship and Small Business, 6(3), 465-478. https://doi.org/10.1504/IJESB.2008.019139

McElwee, G., \& Robson, A. (2005). Diversifying the farm: Opportunities and barriers. Finnish Journal of Rural Research and Policy, 4(1), 84-96.

McFadden, T., \& Gorman, M. (2016). Exploring the concept of farm household innovation capacity in relation to farm diversification in policy context. Journal of Rural Studies, 46, 60-70. https://doi.org/10.1016/j.jrurstud.2016.05.006

McGehee, N. G., \& Kim, K. (2004). Motivation for agri-tourism entrepreneurship. Journal of Travel Research, 43(2), 161-170.https://doi.org/10.1177/0047287504268245

McGehee, N. G., Kim, K., \& Jennings, G. R. (2007). Gender and motivation for agritourism entrepreneurship. Tourism Management, 28(1), 280-289. https://doi.org/10.1016/j.tourman.2005.12.022

McNally, S. (2001). Farm diversification in England and Wales-What can we learn from the farm business survey? Journal of Rural Studies, 17(2), 247-257. https://doi.org/10.1016/S0743-0167(00)00050-4 
Meert, H., van Huylenbroeck, G., Vernimmen, T., Bourgeois, M., \& van Hecke, E. (2005). Farm household survival strategies and diversification on marginal farms. Journal of Rural Studies, 21(1), 81-97. https://doi.org/10.1016/j.jrurstud.2004.08.007

Morgan, S. L., Marsden, T., Miele, M., \& Morley, A. (2010). Agricultural multifunctionality and farmers' entrepreneurial skills: A study of Tuscan and Welsh farmers. Journal of Rural Studies, 26(2), 116-129. https://doi.org/10.1016/j.jrurstud.2009.09.002

Morris, W., Henley, A., \& Dowell, D. (2017). Farm diversification, entrepreneurship and technology adoption: Analysis of upland farmers in Wales. Journal of Rural Studies, 53, 132-143. https://doi.org/10.1016/j.jrurstud.2017.05.014

Nandram, S. S., \& Samson, K. J. (2000). Succesvol ondernemen: eerder een kwestie van karakter dan van kennis. Breukelen.

Northcote, J., \& Alonso, A. D. (2011). Factors underlying farm diversification: The case of Western Australia's olive farmers. Agriculture and Human Values, 28(2), 237-246. https://doi.org/10.1007/s10460-010-9274-x

Oreszczyn, S., Lane, A., \& Carr, S. (2010). The role of networks of practice and webs of influencers on farmers' engagement with and learning about agricultural innovations. Journal of Rural Studies, 26(4), 404-417. https://doi.org/10.1016/j.jrurstud.2010.03.003

Penrose, E. E. (1959). The theory of the growth of the firm. Oxford University Press.

Pfeifer, C., Jongeneel, R. A., Sonneveld, M. P. W., \& Stoorvogel, J. J. (2009). Landscape properties as drivers for farm diversification: A Dutch case study. Land Use Policy, 26(4), 1106-1115. https://doi.org/10.1016/j.landusepol.2009.01.007

Pindado, E., \& Sánchez, M. (2018). Growth-oriented new agricultural ventures: the role of entrepreneurial resources and capabilities under convergence forces. European Review of Agricultural Economics, 1-34. https://doi.org/10.1093/erae/jby039

Poza, E. J. (1989). Smart growth: Critical choices for business continuity and prosperity (1st ed.). Jossey-Bass.

Rizov, M., \& Mathijs, E. (2003). Farm survival and growth in transition economies: Theory and empirical evidence from Hungary. Post-Communist Economies, 15(2), 227-242. https://doi.org/10.1080/14631370308093 
Seuneke, P., \& Bock, B. B. (2015). Exploring the roles of women in the development of multifunctional entrepreneurship on family farms: An entrepreneurial learning approach. NJAS-Wageningen Journal of Life Sciences, 74-75, 41-50. https://doi.org/10.1016/j.njas.2015.07.001

Shapiro, D., Bollman, R. D., \& Ehrensaft, P. (1987). Farm size and growth in Canada. American Journal of Agricultural Economics, 69(2), 477-483. https://doi.org/10.2307/1242311

Theuvsen, L. (2003). Kooperationen in der Landwirtschaft: Formen, Wirkungen und aktuelle Bedeutung. Diskussionsbeitrag/Georg-August-Universität Göttingen/Institut für Agrarökonomie. Göttingen: Institut für Agrarökonomie der Universität Göttingen.

Van Praag, C. M. (1999). Some classic views on entrepreneurship. De Economist, 147(3), 311-335. https://doi.org/10.1023/A:1003749128457

Vesala, H. T., \& Vesala, K. M. (2010). Entrepreneurs and producers: Identities of Finnish farmers in 2001 and 2006. Journal of Rural Studies, 26(1), 21-30. https://doi.org/10.1016/j.jrurstud.2009.06.001

Vesala, K. M., Peura, J., \& McElwee, G. (2007). The split entrepreneurial identity of the farmer. Journal of Small Business and Enterprise Development, 14(1), 48-63. https://doi.org/10.1108/14626000710727881

Viira, A.-H., Pöder, A., \& Värnik, R. (2013). The determinants of farm growth, decline and exit in Estonia. German Journal of Agricultural Economics, 62(1). Retrieved from https://ageconsearch.umn.edu/record/232332/files/GJAE_4_Viira.pdf

Vik, J., \& McElwee, G. (2011). Diversification and the entrepreneurial motivations of farmers in Norway. Journal of Small Business Management, 49(3), 390-410. https://doi.org/10.1111/j.1540-627X.2011.00327.x

Weiss, C. R. (1999). Farm growth and survival: Econometric evidence for individual farms in upper Austria. American Journal of Agricultural Economics, 81(1), 103-116. https://doi.org/10.2307/1244454

Weltin, M., Zasada, I., Franke, C., Piorr, A., Raggi, M., \& Viaggi, D. (2017). Analysing behavioural differences of farm households: An example of income diversification strategies based on European farm survey data. Land Use Policy, 62, 172-184. https://doi.org/10.1016/j.landusepol.2016.11.041 
III Analyzing strategic entrepreneurial choices in agriculture - Empirical evidence from Germany

Wolf, P. D., McElwee, G., \& Schoorlemmer, H. (2007). The European farm entrepreneur: A comparative perspective. International Journal of Entrepreneurship and Small Business, 4(6), 679-692. https://doi.org/10.1504/IJESB.2007.014979

Wolf, P. D. \& Schoorlemmer, H., (Eds.). (2007). Exploring the significance of entrepreneurship in agriculture. Switzerland: Frick. 
III Analyzing strategic entrepreneurial choices in agriculture - Empirical evidence from Germany

Appendix A. Different scales, translated from German

Personal risk attitude of the farmer according to Dohmen et al. (2011)

How do you see yourself: are you generally a person who is fully prepared to take risks or do you try to avoid taking risks?

not at all willing to take risks $0 \begin{array}{lllllllllll}0 & 1 & 2 & 3 & 4 & 5 & 6 & 7 & 8 & 9 & 10 \text { very willing to take risks }\end{array}$

Creativity according to Nandram and Samson (2000) and Lauwere (2005),

(C.A. $=0,8276)$

Please indicate to what extent you agree with the following statements.

- I can easily connect related matters

- I like to look at matters from different perspectives

- Other people find me inventive

- I like to consider new things

- If I see that something is going wrong, I like to consider how it can be corrected

- Problems stimulate me to reconsider

Scale used for each item:

$\begin{array}{lllllllll}\text { do not agree at all } & 1 & 2 & 3 & 4 & 5 & 6 & 7 & \text { totally agree }\end{array}$

Farmer's anchoring in values and traditions, items created by the authors

How strongly do you feel that you and your actions in agriculture are anchored in the following aspects?

- Basic Christian values

- Farming tradition

Scale used for each item:

$\begin{array}{llllllllll}\text { not strong at all } & 1 & 2 & 3 & 4 & 5 & 6 & 7 & \text { very strong }\end{array}$

Perceived pressure / external institutions, items created by the authors on the basis of Fitz-Koch et al. (2018)

How strong do you rate the respective pressure that is exerted on you and the company?

- Political / legal pressure

- Societal pressure

- Technical progress (growth pressure)

Scale used for each item:

$\begin{array}{llllllllll}\text { not strong at all } & 1 & 2 & 3 & 4 & 5 & 6 & 7 & \text { very strong }\end{array}$ 
III Analyzing strategic entrepreneurial choices in agriculture - Empirical evidence from Germany

Cooperation, different forms derived from Theuvsen (2003)

In what way do you cooperate with other farmers on the farm?

- cooperation in markets through producer or purchasing groups

- division of labour through contractually regulated neighbourhood assistance, machinery rings or management contracts

- joint use of machinery by fractional communities or machinery companies

- joint management through joint use of facilities (e.g. warehouses, drying facilities etc.), joint stables or operating (branch) companies (e.g. GbR, GmbH)

- I do not work with other farmers in any of these ways. 
Appendix B. Correlation matrix

\begin{tabular}{|c|c|c|c|c|c|c|c|c|c|c|c|c|c|c|c|c|c|c|c|c|}
\hline & 1 & 2 & 3 & 4 & 5 & 6 & 7 & 8 & 9 & 10 & 11 & 12 & 13 & 14 & 15 & 16 & 17 & 18 & 19 & 20 \\
\hline $\begin{array}{c}1 \text { Entrepren. } \\
\text { choice }\end{array}$ & 1.000 & & & & & & & & & & & & & & & & & & & \\
\hline 2 Male & -0.012 & 1.000 & & & & & & & & & & & & & & & & & & \\
\hline 3 Age & $0.014 *$ & 0.040 & 1.000 & & & & & & & & & & & & & & & & & \\
\hline 4 Degree & $-0.066^{*}$ & $-0.095 *$ & $-0.079 *$ & 1.000 & & & & & & & & & & & & & & & & \\
\hline 5 Job & $-0.136 *$ & -0.033 & $-0.141 *$ & $0.037 *$ & 1.000 & & & & & & & & & & & & & & & \\
\hline 6 Creativity & $0.150 *$ & -0.025 & -0.001 & 0.000 & $0.092 *$ & 1.000 & & & & & & & & & & & & & & \\
\hline 7 Risk & $0.176 *$ & 0.106* & 0.029 & -0.036 & 0.023 & $0.332 *$ & 1.000 & & & & & & & & & & & & & \\
\hline 8 Size & $-0.077 *$ & 0.031 & $-0.081 *$ & $0.221 *$ & $-0.098^{*}$ & -0.002 & 0.033 & 1.000 & & & & & & & & & & & & \\
\hline 9 Soil & -0.036 & 0.009 & 0.081* & 0.008 & 0.024 & -0.027 & 0.008 & -0.024 & 1.000 & & & & & & & & & & & \\
\hline 10 Rain & $0.067^{*}$ & $0.095 *$ & $-0.098 *$ & $-0.158^{*}$ & 0.027 & -0.045 & -0.026 & $-0.195 *$ & -0.024 & 1.000 & & & & & & & & & & \\
\hline 11 West & -0.035 & 0.051 & $-0.141 *$ & $-0.190 *$ & $0.115^{*}$ & 0.025 & -0.021 & $-0.515^{*}$ & $0.074 *$ & $0.285^{*}$ & 1.000 & & & & & & & & & \\
\hline 12 Central & 0.040 & -0.029 & -0.027 & $0.078 *$ & 0.031 & -0.024 & -0.055 & -0.002 & 0.054 & 0.059 & -0.042 & 1.000 & & & & & & & & \\
\hline 13 WF_family & $0.070 *$ & $-0.070 *$ & $-0.225 *$ & $-0.096 *$ & $-0.077^{*}$ & $0.077 *$ & $0.106 *$ & $-0.072 *$ & -0.043 & 0.038 & $0.192 *$ & -0.028 & 1.000 & & & & & & & \\
\hline 14 WF_spouse & $0.172 *$ & $-0.075^{*}$ & $0.375 *$ & $-0.147 *$ & -0.044 & 0.046 & $-0.006 *$ & $-0.091 *$ & $-0.070 *$ & -0.019 & 0.024 & 0.016 & $0.095^{*}$ & 1.000 & & & & & & \\
\hline 15 An_values & 0.051 & -0.012 & $0.218^{*}$ & 0.053 & 0.042 & $0.067 *$ & 0.010 & $-0.069 *$ & -0.009 & -0.001 & $0.064 *$ & -0.030 & -0.027 & 0.194* & 1.000 & & & & & \\
\hline 16 An_tradition & -0.058 & -0.055 & $-0.140 *$ & $-0.076 *$ & $0.102 *$ & -0.039 & 0.022 & $-0.099 *$ & -0.037 & -0.014 & 0.025 & -0.003 & 0.027 & -0.017 & $0.322 *$ & 1.000 & & & & \\
\hline 17 Pr_politics & -0.053 & $0.068 *$ & 0.024 & $-0.072 *$ & -0.029 & 0.130* & 0.018 & 0.002 & $-0.106 *$ & $-0.067 *$ & -0.050 & $-0.072 *$ & $0.068 *$ & 0.023 & 0.042 & 0.017 & 1.000 & & & \\
\hline 18 Pr_society & -0.059 & 0.030 & -0.046 & $-0.061^{*}$ & 0.056 & $0.070 *$ & 0.055 & -0.019 & -0.013 & -0.029 & 0.041 & $-0.104 *$ & $0.075^{*}$ & 0.033 & $0.098 *$ & $0.125^{*}$ & 0.433* & 1.000 & & \\
\hline 19 Pr_progress & -0.058 & -0.041 & -0.041 & -0.024 & 0.053 & 0.050 & 0.037 & 0.007 & 0.042 & $-0.109 *$ & 0.038 & $-0.075^{*}$ & 0.023 & 0.029 & 0.118* & $0.143 *$ & $0.115 *$ & 0.191* & 1.000 & \\
\hline 20 Coop & -0.040 & -0.058 & -0.022 & -0.038 & $0.083 *$ & 0.086* & $0.065 *$ & $-0.124 *$ & 0.050 & $0.086 *$ & $0.204 *$ & -0.050 & 0.037 & -0.030 & $0.077 *$ & 0.008 & 0.003 & 0.051 & -0.012 & 1.000 \\
\hline
\end{tabular}

Note: *significant at $\mathrm{p}<0.1$ or better 


\title{
IV Values of Farmers - Evidence from Germany
}

\section{Authors: Viktoria Graskemper, Jan-Henning Feil}

Published in: DARE Discussion Papers (2021): 2101.

\begin{abstract}
Against the background of fundamentally changing political and social requirements of agricultural production, the requirement profile of farmers has changed. The future of agriculture is widely discussed. To prepare a ground for future debates and policy programme design, it is essential to get an understanding of which values underlie farmers' behaviour. This paper applies Schwartz' value theory to a large quantitative survey $(\mathrm{N}=787)$ of German farmers. Next to the overall value portrait, different value portraits within the sample of farmers are analysed. Farmers of the sample first and foremost prioritise selftranscendence values followed by openness to change. Conservation and self-enhancement are ranked to be less important within farmers' value priorities. Furthermore, three different value portraits are identifiable within the sample. These groups differ significantly among other things in their risk attitude and involvement in structural diversification. Implications for agricultural policy design and agricultural management are derived from the results.
\end{abstract}

Keywords: farmer values, PVQ, agricultural values, entrepreneurship 


\section{Introduction}

Combining business interests and life goals is a challenge farmers face in a particular way (Ilbery, 1978; Fairweather and Keating, 1994; Inhetveen and Schmitt, 2010). Farm management differs from purely commercial enterprises in that a traditional, family-run farm organisation often prevails, with farm management decisions having a direct influence on daily life both private and business (Ashby, 1953; Gasson and Errington, 1993). Furthermore, unlike in other sectors, dependence on natural conditions influences agricultural decisions resulting in considerable production risks (Inhetveen and Schmitt, 2010).

At present, changing consumer demands are a special challenge for farmers in Germany and throughout Europe. These lead to demands towards a higher social contribution to the long-term conservation of nature and its resources (Morris and Potter, 1995; Kuhnert, 1998; Rudmann, 2008; Grethe et al., 2018). This is reflected in a change of direction in agricultural policy towards a more extensive and multifunctional agriculture by making environmental services more binding or by tightening rules of animal husbandry as well as in a call for entrepreneurship in agriculture (Kirschke et al., 2007; DBV, 2018; Grethe et al., 2018; EC, 2019). Thus, the decision-making process of farmers nowadays is caught between multifaceted goals (Wiesinger, 2005; Grethe et al., 2018).

The identification with the changed requirement profile and the decision between the numerous entrepreneurial choices farmers make are determined by the underlying individual value orientation (Gasson, 1973; Ilbery, 1983). Numerous studies assume that this new profile is only partially compatible with the traditionally based agricultural attitude (Pongratz, 1991; Pyysiäinen et al., 2006; Vesala and Vesala, 2010). In context of a vivid policy debate about the future of agriculture, as reflected for example in the European Green Deal with its Farm to Fork Strategy (EC, 2019), it is essential to know which value portrait underlies the behaviour of farmers. This is the basis to be able to identify their motivational drivers as these are related to entrepreneurial activity (Carsrud and Brännback, 2011; Fayolle et al., 2014), the strategic orientation of the business (Kotey and Meredith, 1997) and its success (Zhao et al., 2010; Leutner et al., 2014). It is also helpful for farmers themselves to be aware of this and to act consciously accordingly. Within debates about the future of agricultural policy it is important to discuss and set targets according to the underlying motivational drivers of the different actors instead of being limited to a purely operational level. 
Existing studies dealing with farmers' values are mostly based on rather small samples and do not investigate differences among the value portraits of farmers. Furthermore, many of them do not differentiate among the different terms of values, goals and motives and their specific impacts (Dobricki, 2011). Often initiated by the pilot study by Gasson (1973) investigating English farmers' goals and values, there are a number of studies dealing with these aspects from various perspectives with samples from different countries across the world (e. g. Kerridge, 1978; Harper and Eastman, 1980; Fairweather and Keating, 1994; Parminter and Perkins, 1997; Willock et al., 1999; Frost, 2000; Bergevoet et al., 2004; Maybery et al., 2005; Teixeira and Vale, 2008; Niska et al., 2012; Duesberg et al., 2013). Regarding Germany, Baur et al. (2016) include a rather old subsample ( $\mathrm{N}=224)$ of German farmers (average age of 60 years) within their analysis of the value portrait of Swiss farmers. Diekmann and Theuvsen (2019) analyse the value portrait of members of community supported agriculture (CSA), meaning a sample of consumers not farmers, in Germany. Apart from these, to the best of the authors' knowledge, there is no study investigating exclusively and in depth the basic values of German farmers on the basis of a large sample and a standardised value theory.

The present study contributes to filling this research gap by investigating the value portrait of German farmers on the basis of a large-scale, quantitative farmer survey $(\mathrm{N}=787)$ including not only questions about the value portraits but also socio-demographic and farm characteristics. For this purpose, the internationally recognised Portrait Value Questionnaire (PVQ) by Schwartz (2003) was used. After analysing the value portrait of German farmers with the help of multidimensional scaling (MDS), a cluster analysis is performed by means of an unsupervised machine learning approach identifying different value portraits among the farmers. Furthermore, differences between personal and farm characteristics between those clusters of different value preferences are analysed.

After giving a background on values in the context of farming, Schwartz's theory on basic human values is introduced. This is followed by a section on the methodology and data. The results are presented and discussed in Section 5. Finally, a conclusion is drawn in Section 6.

\section{$2 \quad$ Values in the context of farming}

The decision-making behaviour of farmers is something that rational economic theories are incapable of accurately explaining, as the structures of enterprises are very interwoven 
(Gasson, 1973) and non-pecuniary benefits make some choices more attractive even though others may be financially more rewarding (Howley, 2015). This is where goals and values come into play. In general, personal values are ascribed a catalyst role for entrepreneurship (Hemingway, 2005). In the following, the concept of values is introduced in demarcation to goals. Afterwards, an overview is given on value research in agriculture.

The heterogeneity found in farm development pathways is also evident in terms of value concepts, which can vary according to perspective and background (Bilsky, 2015). Values are closely linked to motivational goals and guide individual decision-making behaviour (Bardi and Schwartz, 2003). In this context, goals are defined as states or aspirations that a person wishes to achieve, whereby the goals can be either individual goals or intermediate goals in order to pursue the next higher goal. Depending on family circumstances, personal developments or professional influences, goals can change in the course of a life-time (Gasson, 1973; Kerridge, 1978). Values, on the other hand, are defined as fixed notions of desirable states based on deeply rooted and abstract motivations, which are the permanent property of each individual (Gasson, 1973; Schwartz, 2003). The value concepts to be aspired to are relatively independent of the situation and time when going through different phases of life and are justified by reason and moral principles. Values normally cannot be fully satisfied in contrast to concrete goals (Kerridge, 1978; Gasson and Errington, 1993; Kluckhohn, 2013). Determinants of farmers' value orientation are, according to Kerridge (1978), social and economic conditions in which farmers live and grow up in, such as farm size or age. Olver and Mooradian (2003) find values being influenced by personality traits and the environment.

Reviewing the existing literature, Ashby (1926) previously analysed farmers motivation drivers beyond pure profit maximisation. Another pioneering study investigating the motivation of farmers in relation to their behaviour conducted by Gasson (1973) puts a focus on English farmers' personal value system and their goals as determinants, taking into account farming families as well. Overall, this study identified four groups of farmers' values: instrumental, social, expressive and intrinsic values. In relation to agricultural activity, Gasson (1973) finds intrinsic values are of upmost importance for the sample of English farmers, thus, showing a strong intrinsic orientation to work. Social values, which include prestige or affiliation, are of least importance (Gasson, 1973). Depending on study region, sample and study period, other researchers find slightly different priorities among these value groups, yet, social values remain to be the least important ones (e. g. Kerridge, 1978; 
Frost, 2000). Furthermore, Gasson and Errington (1993) identified that important agricultural values are also family values, honesty, and entrepreneurial success and progress.

Several studies agree on the point that the value profile of farmers differs from the general population. Dobricki (2011) and Baur et al. (2016) analysed the PVQ by Schwartz (2003) using data of the European Social Survey (ESS) and found that farmers are less motivated by economic performance and are less open to change than the general population. At the same time they show a strong interest in preserving conservation values, including tradition, conformity and security. They found this value profile particularly pronounced for Austrian, Finnish and German farmers (Baur et al., 2016). Apart from these conservational values, they identified self-transcendence more pronounced than self-enhancement (Dobricki, 2011; Baur et al., 2016). Diekmann and Theuvsen (2019) identified for CSA members a high importance of self-transcendence and openness to change values. Conservational and self-enhancement values appear to be of less importance for this sample. Besides this, they analyse a sample of the German population of the ESS (from 2014) and find selftranscendence values of major and self-enhancement of minor importance, conservation and openness to change of rather equal importance.

Some studies use the farmers' value priorities to draw conclusions for the acceptance and implementation of agri-environmental programmes. Such programmes should be designed in a way that highlights the added value for society and the environment in the long-run and be less based on monetary incentives (Morris and Potter, 1995; Frey, 1997; Grüner and Fietz, 2013; Baur et al., 2016). Excessive regulation and sanctions can lead to farmers no longer carrying out voluntary actions out of their own intrinsic motivation because they are no longer self-determined and do not feel valued enough (Frey, 1997). Building on the work of Gasson (1973), Duesberg et al. (2013) find that the participation in afforestation schemes in Ireland is related to the farmers' intrinsic, instrumental, social and expressive farming values which sometimes contradict themselves. Most farmers are guided by their intrinsic values in relation to farm afforestation, a much smaller group by profit maximisation. Gravsholt Busck (2002) furthermore investigates the relationship between the values of farmers and their landscape practice in Denmark coming to the result that those practices can be conceptualised on the basis of different value profiles. Moreover, Hansson and Sok (2021) use the values self-transcendence and conservation as described by Schwartz as covariates for explaining the latent variable of perceived obstacles for business development of Swedish farmers but did not find an effect. 
Moreover, Inhetveen and Schmitt (2010) describe that independence and selfdetermination are of upmost importance for German farmers. Niska et al. (2012) find similar results for the autonomy of Finnish farmers. In Niska et al.'s (2012) study, autonomy values are followed by economy, societal and inter-generational continuity. Confirming the results regarding the importance of continuity of the farm, Schoon and Grotenhuis (2000) find furthermore, societal appreciation, and perceptions of nature as topics of great concern for a sample of Dutch farmers where the relation between convictions, values and behavior is qualitatively investigated.

Results from Parminter and Perkins (1997) on farmers from New Zealand show that they identify primarily with values in pursuit of entrepreneurial goals and interpret the achievement of these values as their personal success, which distinguishes them from the general population. In addition, a group of farmers in the study also prioritise values related to the well-being of others and the protection of natural resources.

\section{SCHWARTZ's theory on basic human values}

Within the social sciences, there are various studies and models about human principles (Rokeach, 1973; Inglehart, 1977; Hofstede, 1980; Schwartz and Bilsky, 1987, 1990). Schwartz's Theory of Basic Human Values from 1992 makes the claim that the various perspectives of value research can be combined into one. It is highly recognised in international academic literature as it can be applied universally and cross-culturally, independent of the respondent's intellect.

The value theory is based on three basic assumptions. The first assumption assumes that the ten basic values of the theory can be described by five formal characteristics: values are concepts or rather ideas which address desirable final stages or behavioural patterns; values can endure concrete situations, negotiations and norms; they allow a choice or assessment of behaviour patterns or incidents; and they are arranged hierarchically (Schwartz and Bilsky, 1987, 1990). Each value type, as described in Table 1, is worded to reflect on existential and basic human needs (Schwartz, 1992; Bardi and Schwartz, 2003). The descriptions of the ten value types are to be understood as the synthesis of the individual motivational aims which are the result of a person's individual values.

The second assumption is that the value types in the value system are subject to mutual relationships in which, depending on the value type, either content-related conflicts of objectives or harmonious relationships predominate (Schwartz and Sagiv, 1995). Graphically, 
these interrelationships become clear through the specific arrangement in a circular structure (Bilsky et al., 2011), as illustrated in Figure 1.

Table 1: Definitions of motivational types of values in terms of their goals, single values and higher-order values. Source: adjusted from Schwartz (2009)

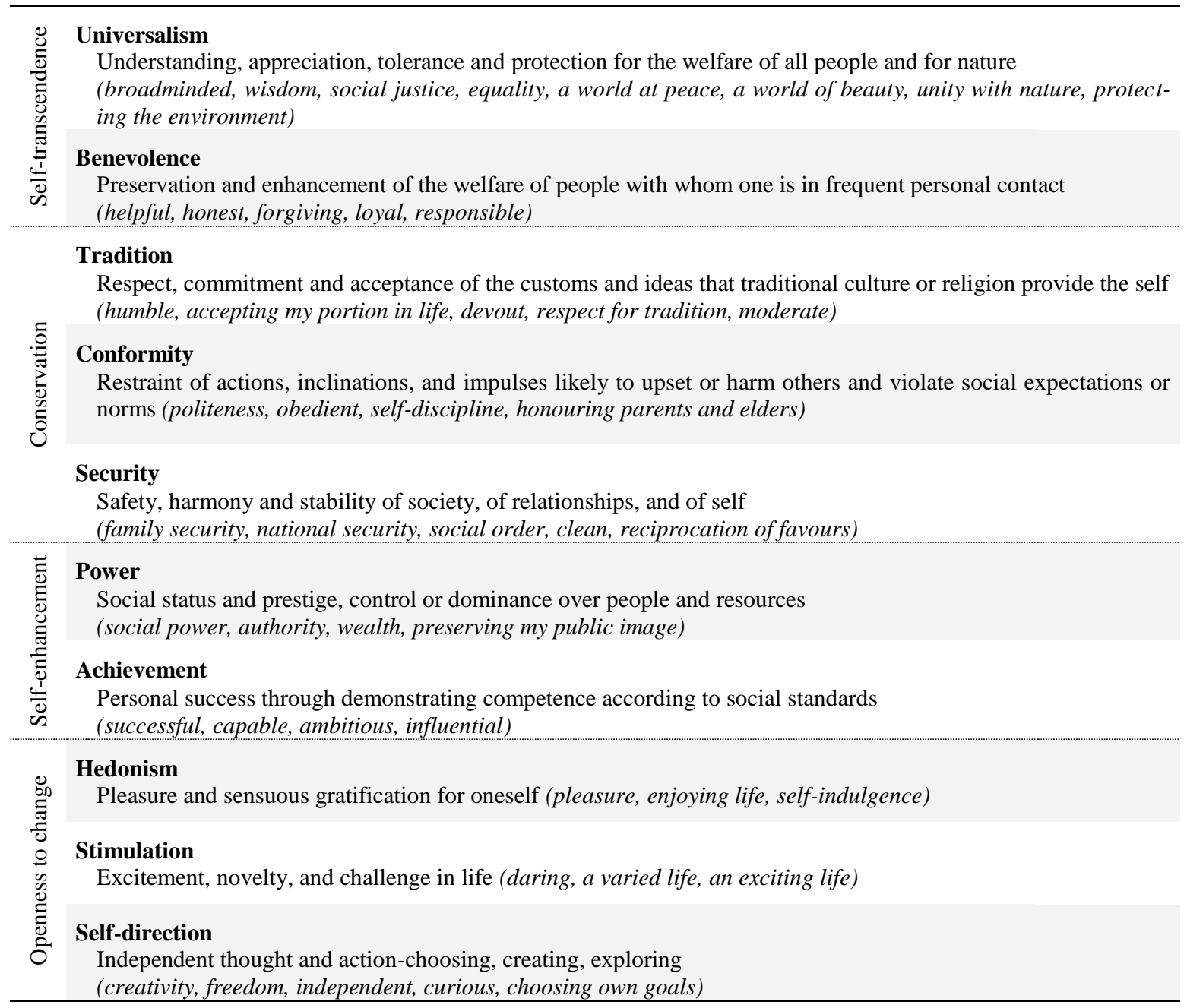

The third theoretical assumption is that the ten competing or harmonising value types can be summarised more generally into four higher order values. The four higher-order values are each grouped into two opposing pairs of value types, which in turn are opposite of each other in a circle (Schwartz, 1992; Schwartz and Sagiv, 1995; Schwartz, 2003, 2012). Hedonism is the only value type that shares elements of self-enhancement and openness to change. In the literature, this type is predominantly associated with openness to change (Schwartz, 1992, 2003, 2012) as is also the case in this study. 


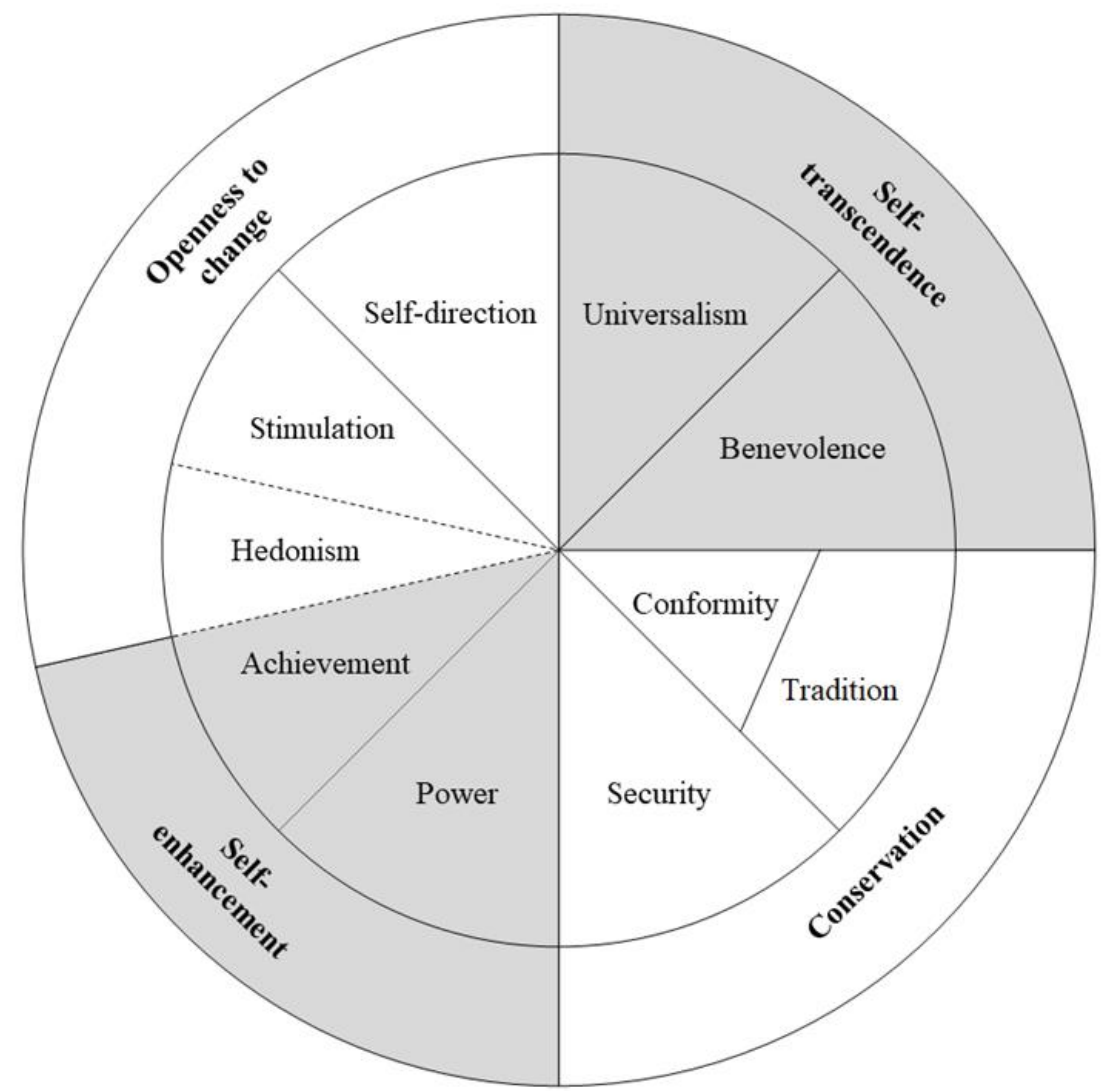

Figure 1: Value arrangement

Source: adjusted from Schwartz (1992) and Bilsky et al. (2011)

\section{$4 \quad$ Data and methodology}

Within the following section, the sample and the data collection process are described first. Afterwards, the statistical analysis of the values using the PVQ and MDS is described. Finally, the applied clustering approach is presented.

\subsection{Sample}

The PVQ was included in a quantitative online survey on entrepreneurship in agriculture among German farmers. As the study subject is a forward-looking topic, farm successors who already work on the farm and who are significantly involved in management and development of the operation are included in the sample as well. Next to the PVQ, the survey included questions concerning the farmer, the farm and the context. The data collection took place from November 2018 until February 2019. The survey link and the barcode were distributed through various channels; promotion on the homepages, social media channels, newsletters and e-mail distribution lists of different agricultural institutions, such as (young) farmers' associations and rural education centres, publications within articles of 
regional and national agricultural magazines, direct acquisition of farmers during an agricultural fair, and distribution of flyers at various farmer events. This led to 926 completed questionnaires. From these, in total 62 were led automatically to the end of the survey as they did not fit the target group, 62 questionnaires were excluded because of big outliers or inconsistencies within the responses, and another 15 were deleted due to missing or repeated answers within the PVQ. This resulted in a sample size of 787. Descriptive statistics are to be found in Table 2 .

The mean age is 38 years and considerably younger than the German average where $34 \%$ of all German farmers are above the age of 55 (DBV, 2018). This can be explained by the inclusion of the young generation of farmers. This inclusion facilitates a full picture of the values of all active farmers as there is often a transition period between two generations of farmers working together but not being registered separately. From this perspective, only a rough comparison can be made between the census data and the sample at hand to put some main numbers into perspective. Of the surveyed sample, $85 \%$ of the participants are male. This is in line with the census which states $90 \%$ of farms are managed by men (DBV, 2018). Regarding education, $42 \%$ hold a third-level degree which is higher than $12 \%$ within the official data (DBV, 2018) and $89 \%$ received agricultural vocational training. This higher share may be caused by a more open-mindedness for supporting research by farmers who received a third-level education. As farming is mainly a family business in Germany, most farmers grew up on a farm.

Regarding farm characteristics, the average amount of land of 312 ha is higher compared to 62 ha within official data from 2017 (DBV, 2018) and might be explained by a high share of full-time farms $(87 \%)$ and the comparably high share of farms with a location in the new federal states where historically larger farm structures dominate. The fact that most farmers indicate a focus on arable farming might be explained by the fact that some farmers may have stated this in combination with animal husbandry. The pursued diversification activities of the farmers are categorised in agricultural and structural diversification according to the definition of Ilbery (1991), adjusted to the present situation. Agricultural diversification comprises the keeping of unconventional animal breeds, the cultivation of unconventional crops, and all activities in the area of forestry as well as agricultural contraction / wage services. Structural diversification consists of overnight accommodation, leisure activities, alternative marketing and distribution channels, processing of agri- 
cultural products, solidary / social / educational activities, and the leasing of land and buildings.

Table 2: Descriptive statistics of the variables

\begin{tabular}{|c|c|c|c|c|c|c|}
\hline Variable & Definition & Scale / measurement & Mean & SD & Min & Max \\
\hline \multicolumn{7}{|l|}{ Farmer } \\
\hline Age & Age & number of years & 38.38 & 12.89 & 19 & 74 \\
\hline Male & Gender & $1=$ male $; 0=$ female & 0.85 & 0.36 & 0 & 1 \\
\hline Degree & $\begin{array}{l}\text { Third-level education; degree from a } \\
\text { university or university of applied } \\
\text { sciences }\end{array}$ & $1=$ yes $; 0=$ no & 0.42 & 0.49 & 0 & 1 \\
\hline Edu_agr & Agricultural education & $1=$ yes $; 0=$ no & 0.88 & 0.32 & 0 & 1 \\
\hline Partnership & Living in a partnership & $1=$ yes $; 0=$ no & 0.75 & 0.43 & 0 & 1 \\
\hline Job & Off-farm job of the farmer & $1=$ yes $; 0=$ no & 0.30 & 0.46 & 0 & 1 \\
\hline Childhood & Relation to farming during childhood & $\begin{array}{l}1=\text { grown up on a farm; } 2= \\
\text { farm in the family; } 3=\text { work- } \\
\text { ing on neighbour farm; } 4= \\
\text { no relation to agriculture }\end{array}$ & 1.24 & 0.66 & 1 & 4 \\
\hline Risk & $\begin{array}{l}\text { Risk attitude according to Dohmen et } \\
\text { al. (2011) }\end{array}$ & $\begin{array}{l}0=\text { not at all willing to take } \\
\text { risks; } 10=\text { very willing to } \\
\text { take risks }\end{array}$ & 6.00 & 1.91 & 0 & 10 \\
\hline \multicolumn{7}{|l|}{ Farm } \\
\hline Position & Farmer of the operation & $1=$ farmer $; 0=$ successor & 0.66 & 0.47 & 0 & 1 \\
\hline Familyfarm & Family farm & $1=$ yes $; 0=$ no & 0.88 & 0.33 & 0 & 1 \\
\hline Size & Farm size, total area under cultivation & number of hectares & 312.71 & 634.14 & 1 & 6200 \\
\hline Size_initial & $\begin{array}{l}\text { Initial farm size, total area under } \\
\text { cultivation }\end{array}$ & number of hectares & 249.94 & 583.60 & 1 & 6200 \\
\hline Fulltime & Farming business in full-time & $1=$ yes $; 0=$ no & 0.87 & 0.34 & 0 & 1 \\
\hline Organic & Organic farming & $1=$ yes $; 0=$ no & 0.11 & 0.32 & 0 & 1 \\
\hline Foc_arable & Focus on arable farming & $1=$ yes $; 0=$ no & 0.69 & 0.46 & 0 & 1 \\
\hline Foc_fordairy & Focus on forage crops and dairy cattle & $1=$ yes $; 0=$ no & 0.31 & 0.46 & 0 & 1 \\
\hline Foc_foroth & Focus on other forage crops & $1=$ yes $; 0=$ no & 0.17 & 0.37 & 0 & 1 \\
\hline Foc_refine & Focus on refinement; pigs or poultry & $1=$ yes $; 0=$ no & 0.31 & 0.46 & 0 & 1 \\
\hline Foc_horti & Focus on horticulture & $1=$ yes $; 0=$ no & 0.02 & 0.15 & 0 & 1 \\
\hline Foc_perma & Focus on permanent crops & $1=$ yes $; 0=$ no & 0.06 & 0.24 & 0 & 1 \\
\hline Div_agr & Agricultural diversification & $1=$ yes $; 0=$ no & 0.45 & 0.50 & 0 & 1 \\
\hline Div_str & Structural diversification & $1=$ yes $; 0=$ no & 0.45 & 0.50 & 0 & 1 \\
\hline Renew_en & $\begin{array}{l}\text { Renewable energy (biogas, wind, } \\
\text { solar) }\end{array}$ & $1=$ yes $; 0=$ no & 0.56 & 0.50 & 0 & 1 \\
\hline Soil & $\begin{array}{l}\text { Average soil quality on the agricul- } \\
\text { tural main site according to the Ger- } \\
\text { man system of "Ackerzahl" }\end{array}$ & points $1-100$ & 47.15 & 17.95 & 10 & 100 \\
\hline Rain & $\begin{array}{l}\text { Average rainfall on the agricultural } \\
\text { main site in } \mathrm{mm} / \text { year }\end{array}$ & number mm / year & 700.75 & 179.85 & 250 & 1500 \\
\hline West & $\begin{array}{l}\text { Location of agricultural sites in the } \\
\text { old German states }\end{array}$ & $1=$ yes $; 0=$ no & 0.86 & 0.35 & 0 & 1 \\
\hline Central & $\begin{array}{l}\text { Location of the agricultural main site } \\
\text { near a metropolitan area or tourist / } \\
\text { recreation region }\end{array}$ & $1=$ yes $; 0=$ no & 0.11 & 0.31 & 0 & 1 \\
\hline Wf_family & $\begin{array}{l}\text { Number of family workers in the } \\
\text { business }\end{array}$ & number of family workers & 1.87 & 1.10 & 0 & 6 \\
\hline Wf_spouse & $\begin{array}{l}\text { Spouse works / assists on the farm / } \\
\text { in the business }\end{array}$ & $1=$ yes $; 0=$ no & 0.35 & 0.48 & 0 & 1 \\
\hline Coop & Cooperation with other farmers & $1=$ yes $; 0=$ no & 0.78 & 0.42 & 0 & 1 \\
\hline
\end{tabular}


According to Weltin et al. (2017), these are mainly on-farm diversification activities whereas off-farm activities are represented by the farmer's off-farm job. Compared to the census data where one-third of German farmers is engaged in diversification activities, including renewable energy production (DBV, 2018), the share of $45 \%$ stating to pursue agricultural diversification and another $45 \%$ towards structural diversification is rather high and equally distributed. That renewable energy production is listed separately and shows a high involvement (56\%) is to be traced back to a massive political push in Germany towards an investment in this area (UBA, 2019). On average 1,87 family members and $35 \%$ of the spouses work within the business. Cooperation with other farmers (78\%) is common within the sample.

\subsection{Statistical analysis of the values}

The Schwartz (2003) 21-Item PVQ applied in this study is means to measure the ten theoretical value types which can be well integrated into a survey due to its brevity (Schmidt et al., 2007). It consists of 21 items which present short, easily understandable, verbal portraits of 21 persons, as attached in the Appendix. These portraits express objectives, attitudes or wishes that can be explicitly assigned to one of the ten value types. The respondents are asked to compare the statements with themselves on a 6-level likert scale $(1=$ not like me at all; $6=$ very much like me). This form of questioning focuses on the content of the portraits without directly addressing the value types. Consequently, a truthful answer can be assumed. Farmers' inner attitudes and value systems come to light and the risk of socially desirable answers is lower (Schmidt et al., 2007).

With the help of a non-metric or ordinal MDS, the value model with interrelationships is visualised by transferring coordinates of the ten basic values into a two-dimensional diagram. Similarities or dissimilarities among the values are illustrated by their distances between the value points resulting from the intercorrelations (Borg and Staufenbiel, 2007). In preparation for the MDS, the variables must be adjusted and summarised (Schwartz, 2005a). As there are different formulations for both women and men, the different data was merged first into the 21 items. Data sets containing at least five missing items and 15 or more identical answers were deleted. Subjects who did not distinguish between the 21 items were excluded. An index was created for the ten unprocessed raw basic values by calculating mean values from the answers of the specific items for each value type. The summary of the four higher order values is done in the same way as the index formation. The reliability of the raw indices was tested by a reliability analysis using Cronbachs $\alpha$ 
(Schwartz, 2003). To be able to consider the relative importance of the individual value types within the value system, in a final preparatory step, the various individual scale uses in answering are ipsatised by calculating the average score for each participant from the given answers and subtracting it from the absolute score (Schwartz, 2003; Fischer, 2004; Schwartz, 2005b; Fischer and Milfont, 2010).

For the subsequent confirmatory structural analyses, a symmetrical $10 \times 10$ matrix from the Pearson correlation coefficients of the ten value types was created. Furthermore, a theoretical starting configuration, a design matrix, to which the determined correlation coefficients of the farm managers are aligned was used because the base coordinates for each theoretical value type are exactly defined and represent the basic values in the theoretical circular structure as proposed by Schwartz (2003). By doing so, a uniform creation of the MDS in the sense of the value theory is guaranteed and the determined MDS of the farmers can be compared with the model (Bilsky et al., 2011). By using a design matrix as a basis, the MDS is a weak confirmatory MDS. Kruskal's stress-I measure is used as a quality criterion of the MDS to measure the stresses of the solutions. The perfect solution is present at stress- $\mathrm{I}=0$, an excellent solution is present at stress-I $<0.025$, for $<0.05$ the solution is considered good, for $<0.1$ it is considered sufficient and for $<0.2$ it is considered deficient (Kruskal, 1964; Borg and Staufenbiel, 2007).

\subsection{Clustering}

Clustering is a form of unsupervised learning. The aim is to identify patterns within the data set and to create groups where the members are as similar as possible within the same group and as different as possible between the groups (Lesmeister, 2015). The aim of using a clustering approach subsequent to the value analysis is to identify differences within the value portraits of the sample of farmers. As throughout the evaluation process the ten basic variables turned out to be not sufficiently reliable in isolation, the four higher order values were used for the clustering. Other studies tackled this issue in a similar manner, e. g. Baur et al. (2016) or Dobricki (2011).

In general, clustering methods are distinguished into hierarchical and partitioning approaches. As the data is quasimetric, a lot of different methods can be applied. To identify outliers, we first applied a hierarchical method using Euclidean Distance and Single Linkage (Backhaus et al., 2018). Thus, nine observations were excluded from the sample. For the final clustering k-means using Euclidean distance measure was chosen. This method 
can handle big data sets and results in an even and reasonable distribution of the observations at hand. K-means minimises the within-cluster variation and iterates until each observation belongs to just one cluster. In contrast to the hierarchical clustering, each observation can be reshuffled to the cluster with the centroid. A precondition is to specify the number of clusters beforehand (Lesmeister, 2015).
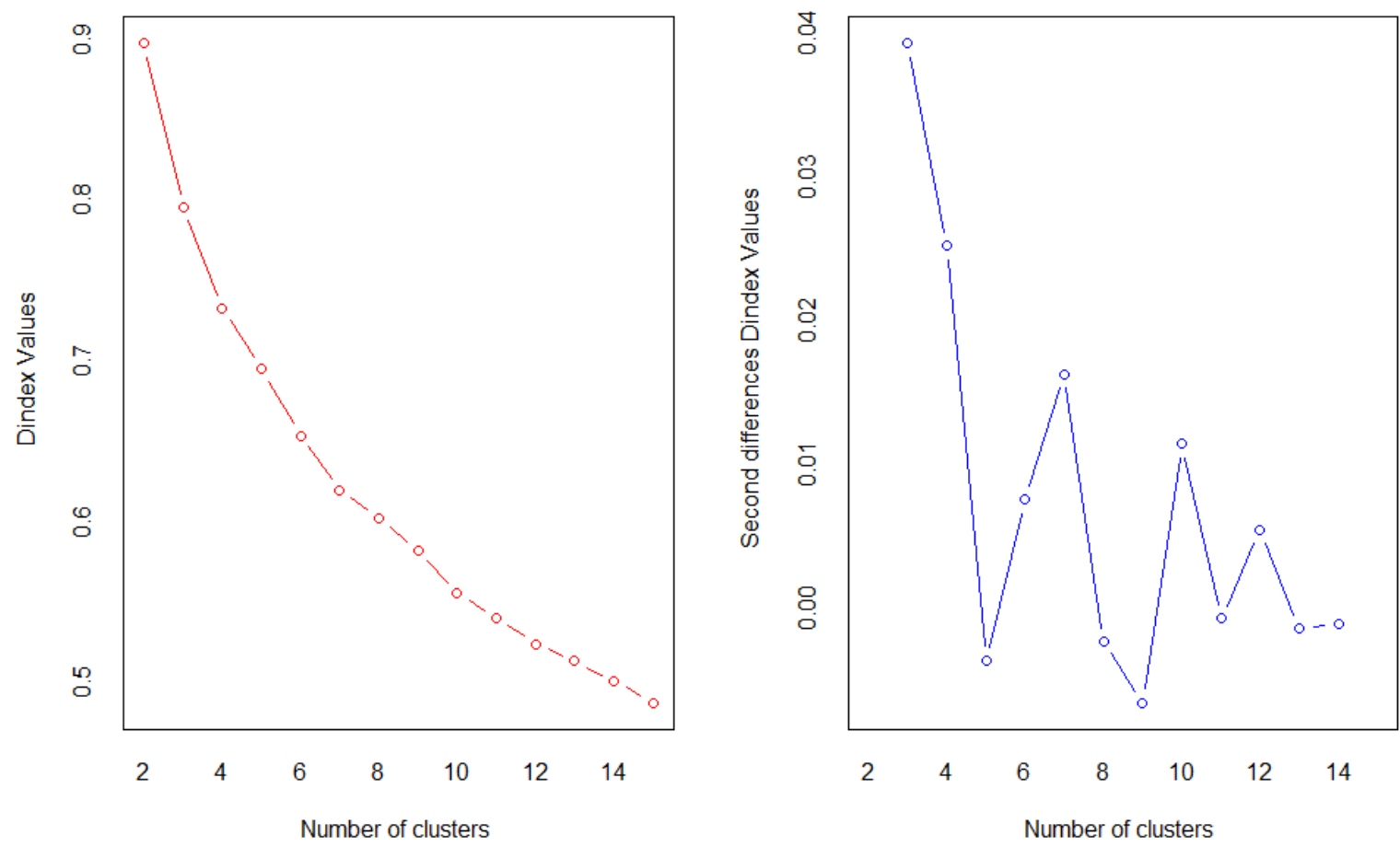

Figure 2: Results of the Elbow method

To determine the best number of clusters, the Elbow method using the within-cluster sum of squares is used. This reveals that three is the optimal number of clusters as illustrated in Figure 2. Furthermore, the 23 other criteria for selecting the optimal number of clusters provided by $\mathrm{R}$ programme $\mathrm{NbClust()} \mathrm{command} \mathrm{were} \mathrm{considered} \mathrm{as} \mathrm{well} \mathrm{whereby} \mathrm{a} \mathrm{majori-}$ ty of eight confirmed the optimal number of three clusters.

To compare the clusters in relation to different farmer and farm characteristics, arithmetic means and their standard deviations are calculated along with the p-values to test equality between groups.

\section{$5 \quad$ Results and discussion}

The results of the MDS are presented and discussed first to approve the value theory. These are followed by the value portrait of the overall sample and finally the value clusters within the sample. 


\subsection{Visualisation and applicability of the value portrait}

The results of the MDS, as illustrated in Figure 3, represent the circular arrangement of the ten value types from the theoretical value model in Figure 1. More strongly correlating value pairs, such as benevolence and universalism, are closer together where opposite value pairs, such as hedonism and tradition, are further apart. Furthermore, there is conformity with theory in the regional arrangement of the four higher-order value pairs.

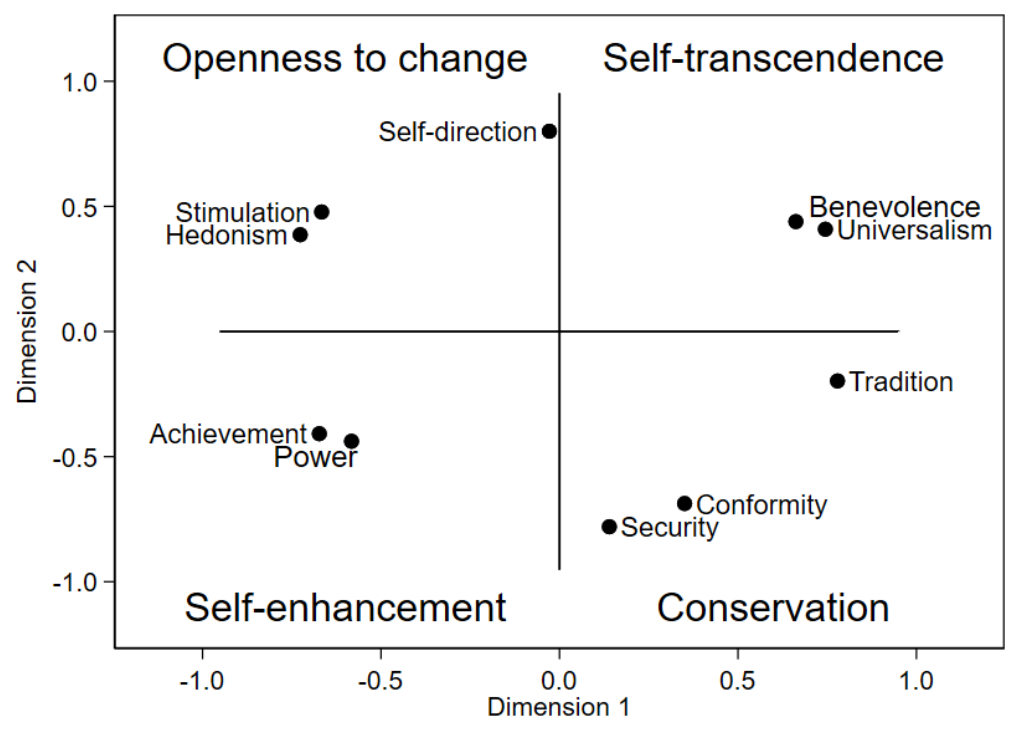

Figure 3: Results of the MDS (N=787)

There are some slight differences to the theory. Some of the positively correlating pairs of values are closer to each other than the value theory would suggest. Benevolence and universalism are interchanged in the present MDS. Conformity is closer to the value security instead of being a bit more in the centre in front of the value tradition. The values tradition and self-direction have a large distance to their higher order partners and lie separately in the solution. Tradition is as positively correlated with universalism $(\mathrm{r}=0.12)$ as it is with conformity $(\mathrm{r}=0.12)$. This could indicate that tradition in the agricultural context is also connected to self-transcendent values. Running the family farm might be associated with the preservation of the family welfare and a protection of the cultural landscape, which in turn are self-transcendent values (Pongratz, 1991). It might also be an issue of the wording of the items as it occurs in other studies applying the PVQ as well. The separate position of the value self-direction may be explained by the findings of Inhetveen and Schmitt (2010) and Niska et al. (2012) who find top priorities for farmers' independence, selfdetermination and autonomy. From these results it can be concluded that farmers distinguish this value more strongly from hedonism and stimulation. However, the stress-I measure of the MDS is 0.036 , meaning that the quality of the model can be described as 
good (Kruskal, 1964). Thus, the value theory according to Schwartz (1992) proves to be an appropriate method for mapping and structuring the value orientation of farmers.

Before computing the MDS, the reliability of the ten raw indices was analysed by their Cronbachs $\alpha$ between the respective items. The values hedonism $(\alpha=0.74)$ and stimulation $(\alpha=0.68)$ are best described by their items. Since the basic values are described by only two or three items, Schwartz (2005a) sets a lower Cronbachs $\alpha \geq 0.4$. Tradition $(\alpha=0.23)$ fails to reach this threshold and both power $(\alpha=0.36)$ and self-direction $(\alpha=0.37)$ barely pass. The Cronbachs $\alpha$ improve after merging to the four higher order values: openness to change $\alpha=0.72$, self-enhancement $\alpha=0.66$, self-transcendence $\alpha=0.62$, and conservation $\alpha=0.61$. This is why the following calculations focus on the higher order values, as previous studies did as well (e. g. Dobricki, 2011; Baur et al., 2016).

\subsection{Description of the overall value portrait}

Regarding the value priorities of the whole sample as described in Table 3, selftranscendence is the most pronounced value (mean $(\mathrm{M})=0.47$ ), followed by openness to change $(M=0.12)$. Conservation $(M=-0.26)$ and self-enhancement $(M=-0.37)$ which are less dominant in the farmers' value portrait. The high ranking of openness to change and the low ranking of conservation contradicts the findings of previous studies using the PVQ among farmers. Dobricki (2011) finds top priority for conservation and least for openness to change for farmers from Switzerland. For German farmers, Baur et al. (2016) find conservation second $(M=0.31)$ and openness to change third priority $(M=-0.5)$. One reason for this might be due to the composition of the samples with regards the age distribution. While farmers in the studies of Dobricki (2011) and Baur et al. (2016) are 60 years on average, the mean age of farmers in this sample is 38 years. It might be argued that the present sample reflects the value portrait of the active and upcoming farmer generation, and thus is more future-oriented. In order to sustain the change process towards a more multifunctional agriculture and new development pathways (Kirschke et al., 2007; DBV, 2018; Grethe et al., 2018), it may be argued that the farmers of the sample at hand are open for change and are less conservative than the previous farmers have been. 
Table 3: Descriptive statistics of the value clusters

\begin{tabular}{|c|c|c|c|c|}
\hline & 1 & 2 & 3 & p.overall \\
\hline & $\mathrm{N}=284$ & $\mathrm{~N}=268$ & $\mathrm{~N}=235$ & \\
\hline \multicolumn{5}{|c|}{ Higher-order values included within cluster analysis } \\
\hline Self-transcendence & $0.17(0.47)$ & $0.46(0.47)$ & $0.85(0.43)$ & $<0.001$ \\
\hline Openness to change & $0.43(0.41)$ & $-0.42(0.41)$ & $0.34(0.44)$ & $<0.001$ \\
\hline Self-enhancement & $0.12(0.45)$ & $-0.29(0.50)$ & $-1.06(0.43)$ & $<0.001$ \\
\hline Conservation & $-0.66(0.46)$ & $0.22(0.34)$ & $-0.34(0.42)$ & $<0.001$ \\
\hline \multicolumn{5}{|l|}{ Descriptive variables } \\
\hline Age & $34.0(11.3)$ & $39.2(12.5)$ & $42.7(13.6)$ & $<0.001$ \\
\hline Male & $0.87(0.34)$ & $0.85(0.36)$ & $0.82(0.38)$ & 0.312 \\
\hline Degree & $0.48(0.50)$ & $0.40(0.49)$ & $0.37(0.49)$ & 0.027 \\
\hline Edu_agr & $0.90(0.30)$ & $0.87(0.33)$ & $0.89(0.31)$ & 0.623 \\
\hline Partnership & $0.70(0.46)$ & $0.74(0.44)$ & $0.82(0.38)$ & 0.005 \\
\hline Job & $0.28(0.45)$ & $0.34(0.47)$ & $0.28(0.45)$ & 0.261 \\
\hline Childhood & $1.18(0.59)$ & $1.26(0.67)$ & $1.29(0.72)$ & 0.157 \\
\hline Risk & $6.60(1.73)$ & $5.06(1.85)$ & $6.36(1.79)$ & $<0.001$ \\
\hline Position & $0.56(0.50)$ & $0.69(0.46)$ & $0.76(0.43)$ & $<0.001$ \\
\hline Familyfarm & $0.89(0.32)$ & $0.87(0.34)$ & $0.88(0.33)$ & 0.742 \\
\hline Size & $300(608)$ & $343(694)$ & $293(593)$ & 0.621 \\
\hline Size_initial & $230(542)$ & $273(616)$ & 249 (596) & 0.690 \\
\hline Fulltime & $0.89(0.32)$ & $0.82(0.38)$ & $0.89(0.31)$ & 0.032 \\
\hline Organic & $0.08(0.28)$ & $0.11(0.31)$ & $0.15(0.36)$ & 0.066 \\
\hline Foc_arable & $0.69(0.46)$ & $0.66(0.47)$ & $0.73(0.44)$ & 0.251 \\
\hline Foc_fordairy & $0.31(0.46)$ & $0.34(0.48)$ & $0.28(0.45)$ & 0.269 \\
\hline Foc_foroth & $0.13(0.34)$ & $0.21(0.40)$ & $0.17(0.38)$ & 0.061 \\
\hline Foc_refine & $0.31(0.46)$ & $0.31(0.46)$ & $0.31(0.46)$ & 0.981 \\
\hline Foc_horti & $0.02(0.16)$ & $0.01(0.11)$ & $0.03(0.17)$ & 0.327 \\
\hline Foc_perma & $0.08(0.27)$ & $0.05(0.22)$ & $0.06(0.24)$ & 0.283 \\
\hline Div_agr & $0.47(0.50)$ & $0.44(0.50)$ & $0.43(0.50)$ & 0.663 \\
\hline Div_str & $0.51(0.50)$ & $0.38(0.49)$ & $0.46(0.50)$ & 0.009 \\
\hline Renew_en & $0.56(0.50)$ & $0.54(0.50)$ & $0.58(0.49)$ & 0.681 \\
\hline Soil & 46.8 (17.9) & $47.6(18.4)$ & $47.1(17.6)$ & 0.865 \\
\hline Rain & 702 (176) & 717 (194) & 680 (167) & 0.062 \\
\hline West & $0.89(0.31)$ & $0.84(0.37)$ & $0.83(0.38)$ & 0.057 \\
\hline Central & $0.13(0.34)$ & $0.09(0.29)$ & $0.10(0.30)$ & 0.288 \\
\hline Wf_family & 2.04 & $1.78(1.07)$ & $1.76(1.04)$ & 0.004 \\
\hline Wf_spouse & $0.31(0.46)$ & $0.37(0.48)$ & $0.37(0.48)$ & 0.200 \\
\hline Coop & $0.78(0.41)$ & $0.78(0.41)$ & $0.76(0.43)$ & 0.812 \\
\hline
\end{tabular}

The higher order value openness to change includes the motivational values stimulation, describing a strive for novelty and challenges, hedonism, being characterised by pleasure, enjoying life and self-indulgence, as well as self-direction which includes creativity, independence, freedom and curiosity (Schwartz, 1992). Inhetveen and Schmitt (2010) as well as Niska et al. (2012) stress the major importance of autonomy values, independence and 
self-determination of farmers, which also because of its placement (see Figure 3), play a special role in the value concept of the sample at hand. These findings, in combination with the aforementioned aspects like creativity and a strive for novelty are a prerequisite for entrepreneurial action (Hébert and Link, 1988; van Praag, 1999; EC, 2003) and rated to be of major importance for the farmers within the sample. This suggests that farmers' deep motivational drivers are well compatible with the changing requirement profile constituting a catalyst for entrepreneurship (Hemingway, 2005).

Conservation as a third priority implies respect for tradition, conformity as well as security (Schwartz, 1992). Laoire (2002) attributes low rankings of conservational values to the fact that external conditions such as increased competitiveness on the world market, are causing traditional values to lose relevance, especially among the younger generation, and are increasingly being replaced by entrepreneurial approaches. Bilsky et al. (2011) come to similar conclusions, noting that as interest in unique, new, challenging tasks expressed by the growth values of universalism, benevolence and self-determination increases, there is a simultaneous decline in preferences for traditions and norms.

The high ranking of self-transcendence values is in line with the findings of Baur et al. (2016) who find a mean of 0.75 for German farmers. In other studies those values can also be found among top priorities, though not necessarily first priority (Parminter and Perkins, 1997; Dobricki, 2011; Niska et al., 2012). Universalism is a part of this higher order value being shaped by objectives for tolerance and protection for the welfare of all people and for nature (Schwartz, 1992). This fits the demand for a higher social contribution to the long-term conservation of nature and its resources throughout agriculture (Morris and Potter, 1995; Kuhnert, 1998; Rudmann, 2008; Grethe et al., 2018). This may also be an explanation for the producer identity of farmers described in other studies (Gonzalez and Benito, 2001; Burton, 2004; Burton and Wilson, 2006; Oreszczyn et al., 2010; Vesala and Vesala, 2010).

Benevolence is a component of the higher order value self-transcendence as well, which is further described by the adjectives responsible, helpful, honest, forgiving, loyal and responsible (Schwartz, 1992). The sample consists mainly of family farms so that the prioritisation of benevolence expresses inter alia the family interests of the farmer, which are considered to be particularly important regarding the special position between private and professional interests (Ilbery, 1978; Gasson and Errington, 1993; Fairweather and Keating, 
1994). Similarly, Gasson and Errington (1993) show that honesty is one of the most important values of farmers.

In accordance with the existing literature, farmers rate self-enhancement values as less important (Gasson and Errington, 1993; Dobricki, 2011; Baur et al., 2016). Baur et al. (2016) find a mean of -0.88 for German farmers. Prestige, status, dominance and personal success are less important to them, still it needs to be mentioned that this is just in relation to the degree of the expression. All values are present in the farmers' value portrait. Parminter and Perkins (1997) find farmers from New Zealand identify primarily with values in pursuit of entrepreneurial goals and interpret the achievement of these values as their personal success, which distinguishes them from the general population. Thus, a lower expression of self-enhancement values does not necessarily mean a low expression of entrepreneurship, but self-enhancement might not be the major motivation for their action. What is furthermore worth noting is that the low expression of self-enhancement and the high expression of self-transcendence are in line with the findings from Diekmann and Theuvsen (2019) analysing a German sample, thus, German farmers value portrait of the sample seems not to differ completely from the whole German population.

\subsection{Different value portraits resulting from the cluster analysis}

Having analysed the overall value portrait of German farmers, the question that follows is which different value portraits can be distinguished within the sample and if special farmer or farming types are connected with these. Cluster analysis reveals that three different value portraits can be distinguished on the basis of the higher-order-values, which differ significantly in their value portrait as illustrated in Figure 4.

Farmers within Cluster 1 are characterised by the strongest extent of openness to change and the least expression of conservation as opposing value pairs. Self-transcendence and self-enhancement are relatively equally pronounced. In comparison with the other clusters, they show the lowest level of self-transcendence and the highest level of self-enhancement. Having a closer look at the descriptive statistics in Table 3, these farmers are rather young, well-educated and risk affine. They have the highest share of farm successors within their group, highest shares of diversification activities and most family workers being engaged in the business. 


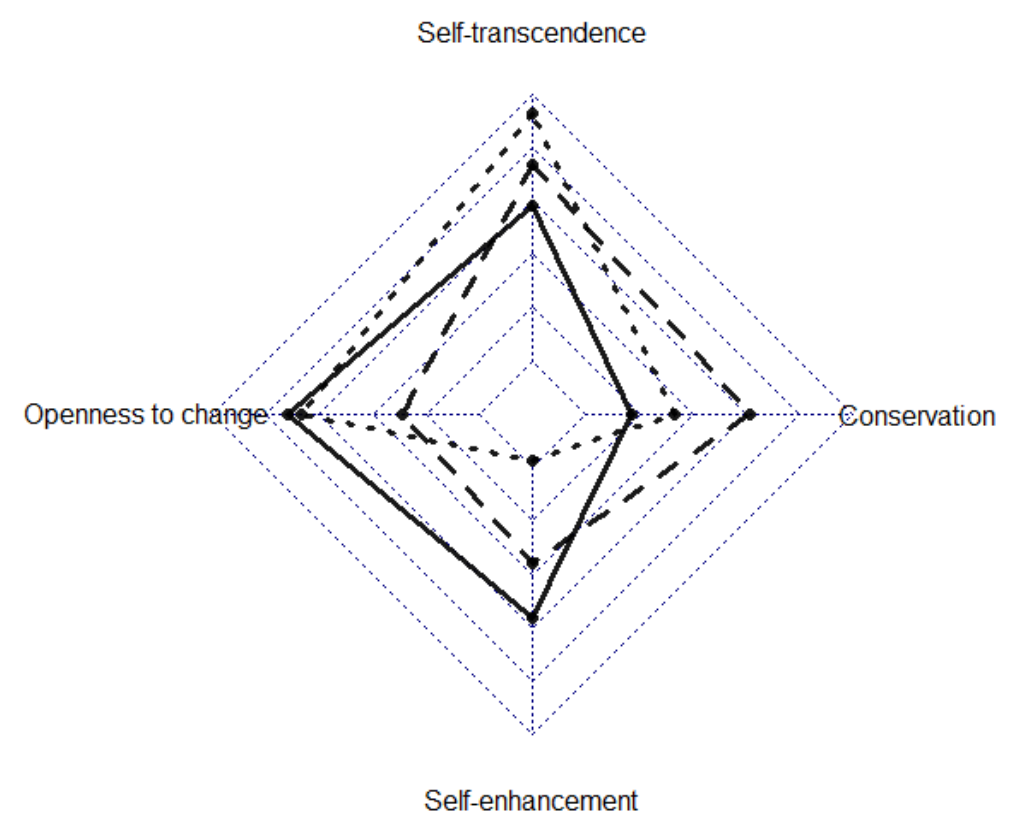

Figure 4: Different value portraits of farmers

Note: - Cluster 1 ; - --Cluster $2 ; \cdots \cdots \cdots . .$. Cluster 3

Cluster 2 distinguishes from the other clusters by having a distinct conservative value orientation and least expression of openness to change. They place high emphasis on selftranscendent values. Self-enhancement is ranked third priority. These farmers are risk neutral, showing the lowest risk affinity among all. The group contains $18 \%$ of part-time farmers which can be interpreted in line with the low risk affinity and the lower degree of openness to change and the lowest rate of structural diversification. Instead of risking something new in the light of structural change and a political push towards multifunctionality in agriculture (Grethe et al., 2018; DBV, 2019), some of them rather rely on revenues from outside the farm yard.

Farmers of Cluster 3 put the highest emphasis of all clusters on self-transcendence, selfenhancement being the least important value. They also emphasise openness to change while they are less conservative. Regarding their characteristics, they are the oldest farmers and thus, they are the farmers with the highest percentage of having a spouse and contain the least number of successors within the sample. They are risk affine and $46 \%$ of them pursue structural diversification.

What is striking is that self-transcendence is the most important value for Clusters 2 and 3 and is ranked second for Cluster 1. Comparing Clusters 1 and 3 reveals that openness to change is of major importance for the youngest and the oldest clusters (34 and 43 years old). This contradicts the findings of Baur et al. (2016), who claim that older farmers are 
more conservative; still, the farmers within the sample at hand are younger in general. Openness to change appears to be more related to risk affinity resulting in structural diversification. This is the only variable which differs significantly among the groups in terms of the farm organisation. Apparently, there is no value portrait determining a special agricultural focus. All value portraits are rather equally distributed among the foci.

\section{Conclusions}

Against the background of fundamentally changing political and social requirements of agricultural production, the requirement profile of farmers has changed. The future of agriculture is widely discussed. To prepare a ground for future debates and policy programme design, it is essential to gain a better understanding of what underlies farmers' behaviour. This is where values come into play. This paper applies Schwartz' value theory to a large quantitative survey $(\mathrm{N}=787)$ of German farmers. Next to the overall value portrait, different value portraits within the sample of farmers are analysed.

The high priority of openness to change and the rather low rating of conservation indicate that the value structures of the farmers within the sample are well compatible with current challenges of a changed requirement profile. The high ranking of self-transcendence means that tolerance and protection for the welfare of people and nature is a matter of great concern to these farmers as well as honesty, loyalty and responsibility. These values are of major importance across the whole sample.

The identified value portraits of the farmers do not correspond with existing conventional farm types, for instance specialised arable, diary or refinement farms. At the same time, the clusters differ with regards to the involvement in structural diversification. With distinct values of openness to change this occurs more often. These farmers are also more risk affine. This implies that the uptake of activities beyond the traditional farming business might be indeed motivated by a special value portrait. Farmers of the more conservative cluster show a higher percentage in part time farming. Thus, the political motivated goal of multifunctionality in agriculture is a concept which cannot be applied to all farmers to the same extent. Every one of them should get the chance to act according to their inner value portrait. Thus, for farmers themselves, it is important to figure out what their inner value preferences are in order to set their goals accordingly. Personal coaching and training might be helpful for this. 
The high rankings in self-transcendence across all clusters reveal that the motivational drivers for an enhanced sustainable action are well-present within the farmers' value portrait. In order to find good solutions, debates about the future of agriculture should rather focus on what deeply motivates farmers to use certain practices and then set goals and the corresponding policy programmes accordingly. By bringing the discussion to a higher level instead of affirming prejudices of political affiliations, commonalities between farmers, nature conservation organisations, and politicians might be found and lead finally to successful solutions. This might also apply for the communication between farmers and society in general.

Furthermore, the high ranking of self-transcendence reveals another issue concerning the communication of current policies; in advertising entrepreneurship and new ways of production, programmes need to focus rather on the benefit for the greater good, such as nature, society and farming families, than the personal success of the single farmer to become widely accepted and adopted.

As limitations of the study it should be mentioned that the sample is rather big but not completely representative for German farmers, especially regarding the age distribution and the education level. Furthermore, Schwartz' value theory is based on self-assessment bearing the risk of being subjective. As a field for future research, the present approach could be applied to other countries to be able to draw comparisons with regard to the value portraits of different farmer groups. Additionally, the farmers' value portrait might be compared to the German average.

\section{CRediT authorship contribution statement}

Viktoria Graskemper: Conceptualization, Investigation, Data Curation, Methodology, Software, Formal analysis, Writing - Original Draft, Visualization. Jan-Henning Feil: Conceptualization, Writing - review \& editing, Supervision. 


\section{References}

Ashby, A.W., 1926. Human motives in farming. Welsh Journal of Agriculture 2, 5-12.

Ashby, A.W., 1953. The Farmer in Business. Journal of proceedings of the Agricultural Economics Society 10, 91-117.

Backhaus, K., Erichson, B., Plinke, W., Weiber, R., 2018. Multivariate Analysemethoden: Eine anwendungsorientierte Einführung, 15th ed. Springer Gabler, Berlin, 625 pp.

Bardi, A., Schwartz, S.H., 2003. Values and Behavior: Strength and Structure of Relations. Personality \& social psychology bulletin 29, 1207-1220.

Baur, I., Dobricki, M., Lips, M., 2016. The basic motivational drivers of northern and central European farmers. Journal of Rural Studies 46, 93-101.

Bergevoet, R.H.M., Ondersteijn, C.J.M., Saatkamp, H.W., van Woerkum, C.M.J., Huirne, R.B.M., 2004. Entrepreneurial behaviour of Dutch dairy farmers under a milk quota system: goals, objectives and attitudes. Agricultural Systems 80, 1-21.

Bilsky, W., 2015. Psychologische Arbeiten zur Struktur menschlicher Werte. Wissenswert $8,5-12$.

Bilsky, W., Janik, M., Schwartz, S.H., 2011. The Structural Organization of Human Values-Evidence from Three Rounds of the European Social Survey (ESS). Journal of Cross-Cultural Psychology 42, 759-776.

Borg, I., Staufenbiel, T., 2007. Lehrbuch: Theorien und Methoden der Skalierung: Eine Einführung, 4th ed. Hans Huber, Bern.

Burton, R.J.F., 2004. Seeing Through the 'Good Farmer's' Eyes: Towards Developing an Understanding of the Social Symbolic Value of 'Productivist' Behaviour. Sociologia Ruralis 44, 195-215.

Burton, R.J.F., Wilson, G.A., 2006. Injecting social psychology theory into conceptualisations of agricultural agency: Towards a post-productivist farmer self-identity? Journal of Rural Studies 22, 95-115.

Carsrud, A., Brännback, M., 2011. Entrepreneurial Motivations: What Do We Still Need to Know? Journal of Small Business Management 49, 9-26.

DBV (Deutscher Bauernverband), 2018. Zukunft wächst auf dem Land: Geschäftsbericht des Deutschen Bauernverbandes 2017/2018. 
DBV (Deutscher Bauernverband), 2019. Situationsbericht 2019/20: Trends und Fakten zur Landwirtschaft, Berlin.

Diekmann, M., Theuvsen, L., 2019. Value structures determining community supported agriculture: insights from Germany. Agriculture and Human Values 36, 733-746.

Dobricki, M., 2011. Basic Human Values in the Swiss Population and in a Sample of Farmers. Swiss Journal of Psychology 70, 119-127.

Dohmen, T., Falk, A., Huffman, D., Sunde, U., Schupp, J., Wagner, G.G., 2011. Individual Risk Attitudes: Measurement, Determinants, and Behavioral Consequences. Journal of the European Economic Association 9, 522-550.

Duesberg, S., O’Connor, D., Dhubháin, Á.N., 2013. To plant or not to plant-Irish farmers' goals and values with regard to afforestation. Land Use Policy 32, 155-164.

EC (European Commission), 2003. Green Paper: Entrepreneurship in Europe COM(2003) 27 final, Brussels. http://ec.europa.eu/invest-inresearch/pdf/download_en/entrepreneurship_europe.pdf.

EC (European Commission), 2019. From farm to fork: The European Green Deal. Publications Office of the European Union, Luxembourg.

Fairweather, J.R., Keating, N.C., 1994. Goals and management styles of New Zealand farmers. Agricultural Systems 44, 181-200.

Fayolle, A., Liñán, F., Moriano, J.A., 2014. Beyond entrepreneurial intentions: values and motivations in entrepreneurship. International Entrepreneurship and Management Journal 10, 679-689.

Fischer, R., 2004. Standardization to account for cross-cultural response bias a classification of score adjustment procedures and review of research in JCCP. Journal of CrossCultural Psychology 35, 263-282.

Fischer, R., Milfont, T.L., 2010. Standardization in psychological research. International Journal of Psychological Research 3, 88-96.

Frey, B.S., 1997. Not Just for the Money: An Economic Theory of Personal Motivation. Elgar, Cheltenham, 156 pp.

Frost, F.M., 2000. Value orientations: impact and implications in the extension of complex farming systems. Australian Journal of Experimental Agriculture 40, 511. 
Gasson, R., 1973. Goals and Values of Farmers. J Agricultural Economics 24, 521-542.

Gasson, R.M., Errington, A., 1993. The farm family business. CAB International, Wallingford, $290 \mathrm{pp}$.

Gonzalez, J.J., Benito, C.G., 2001. Profession and Identity. The Case of Family Farming in Spain. Sociologia Ruralis 41, 343-357.

Gravsholt Busck, A., 2002. Farmers' Landscape Decisions: Relationships between Farmers' Values and Landscape Practices. Sociologia Ruralis 42, 233-249.

Grethe, H., Arens-Azevedo, U., Balmann, A., Biesalski, H.K., Birner, R., Bokelmann, W., Christen, O., Gauly, M., Knierim, U., Latacz-Lohmann, U., Martinez, J., Nieberg, H., Offermann, F., Pischetsrieder, M., Qaim, M., Renner, B., Schmid, J., Spiller, A., Taube, F., Voget-Kleschin, L., Weingarten, P., 2018. Für eine gemeinwohlorientierte Gemeinsame Agrarpolitik der EU nach 2020: Grundsatzfragen und Empfehlungen. Berichte über Landwirtschaft.

Grüner, S., Fietz, A., 2013. Chancen, Grenzen und Barrieren staatlicher Regulierungspolitik - Eine verhaltensökonomische Betrachtung unter Berücksichtigung des individuellen landwirtschaftlichen Unternehmerverhaltens. Schriften der Gesellschaft für Wirtschafts- und Sozialwissenschaften des Landbaues e. V. 49, 3-14.

Hansson, H., Sok, J., 2021. Perceived obstacles for business development: Construct development and the impact of farmers' personal values and personality profile in the Swedish agricultural context. Journal of Rural Studies 81, 17-26.

Harper, W.M., Eastman, C., 1980. An Evaluation of Goal Hierarchies for Small Farm Operators. American Journal of Agricultural Economics 62, 742-747.

Hébert, R.F., Link, A.N., 1988. The Entrepreneur: Mainstream Views \& Radical Critiques, 2nd ed. Praeger, New York, NY, 178 pp.

Hemingway, C.A., 2005. Personal Values as A Catalyst for Corporate Social Entrepreneurship. Journal of Business Ethics 60, 233-249.

Hofstede, G., 1980. Culture's consequences: international differences in work-related values. Sage Publications, Beverly Hills CA.

Howley, P., 2015. The Happy Farmer: The Effect of Nonpecuniary Benefits on Behavior. American Journal of Agricultural Economics 97, 1072-1086. 
Ilbery, B.W., 1978. Agricultural decision-making. Progress in Geography 2, 448-466.

Ilbery, B.W., 1983. Goals and Values of Hop Farmers. Transactions of the Institute of British Geographers 8, 329.

Ilbery, B.W., 1991. Farm Diversification as an Adjustment Strategy on the Urban Fringe of the West Midlands. Journal of Rural Studies 7, 207-218.

Inglehart, R., 1977. The silent revolution: Changing values and political styles among Western publics. Princeton University Press, Princeton, New Jersey, 496 pp.

Inhetveen, H., Schmitt, M., 2010. Prekarisierung auf Dauer? Die Überlebenskultur bäuerlicher Familienbetriebe. In: Bührmann, A.D., Pongratz, H.J. (Eds.) Prekäres Unternehmertum. Unsicherheiten von selbstständiger Erwerbstätigkeit und Unternehmensgründung. VS Verlag für Sozialwissenschaften / GWV Fachverlage GmbH Wiesbaden, Wiesbaden, pp. 111-136.

Kerridge, K.W., 1978. Value orientations and farmer behaviour - an exploratory study [Western Australia]. Quarterly Review of Agricultural Economics.

Kirschke, D., Odening, M., Häger, A., Mußhoff, O., 2007. Strukturwandel im Agrarsektor. Humboldt-Spektrum.

Kluckhohn, C., 2013. Values and value-orientations in the theory of action: an exploration in definition and classification. In: Parsons, T., Shils, E.A. (Eds.) Toward a general theory of action. Harvard University Press, Cambridge, pp. 388-433.

Kotey, B., Meredith, G.G., 1997. Relationships among owner/manager personal values, business strategies, and enterprise performance. Journal of Small Business Management 35, 37-64.

Kruskal, J.B., 1964. Multidimensional scaling by optimizing goodness of fit to a nonmetric hypothesis. Psychometrika 29, 1-27.

Kuhnert, H., 1998. Direktvermarktung in konventionell und ökologisch wirtschaftenden Betrieben: eine Untersuchung zur Direktvermarktung als eine Form der einzelbetrieblichen Diversifikation in der Landwirtschaft. Vauk, Kiel.

Laoire, C.N., 2002. Young farmers, masculinities and change in rural Ireland. Irish Geography $35,16-27$. 
Lesmeister, C., 2015. Mastering Machine Learning with R: Master machine learning techniques with $\mathrm{R}$ to deliver insights for complex projects, Birmingham, UK.

Leutner, F., Ahmetoglu, G., Akhtar, R., Chamorro-Premuzic, T., 2014. The relationship between the entrepreneurial personality and the Big Five personality traits. Personality and Individual Differences 63, 58-63.

Maybery, D., Crase, L., Gullifer, C., 2005. Categorising farming values as economic, conservation and lifestyle. Journal of Economic Psychology 26, 59-72.

Morris, C., Potter, C., 1995. Recruiting the new conservationists: Farmers' adoption of agri-environmental schemes in the U.K. Journal of Rural Studies 11, 51-63.

Niska, M., Vesala, H.T., Vesala, K.M., 2012. Peasantry and Entrepreneurship As Frames for Farming: Reflections on Farmers' Values and Agricultural Policy Discourses. Sociologia Ruralis 52, 453-469.

Olver, J.M., Mooradian, T.A., 2003. Personality traits and personal values: a conceptual and empirical integration. Personality and Individual Differences 35, 109-125.

Oreszczyn, S., Lane, A., Carr, S., 2010. The role of networks of practice and webs of influencers on farmers' engagement with and learning about agricultural innovations. Journal of Rural Studies 26, 404-417.

Parminter, T.G., Perkins, A.M.L., 1997. Applying an understanding of farmers' values and goals to their farming styles. New Zealand Grassland Association 59.

Pongratz, H.J., 1991. Bäuerliche Tradition im sozialen Wandel. Kölner Zeitschrift für Soziologie und Sozialpsychologie 43, 235-246.

Pyysiäinen, J., Anderson, A., McElwee, G., Vesala, K., 2006. Developing the entrepreneurial skills of farmers: some myths explored. International Journal of Entrepreneurial Behavior \& Research 12, 21-39.

Rokeach, M., 1973. The nature of human values. Free Press; Collier-Macmillan, New York, London, 438 pp.

Rudmann, C. (Ed.), 2008. Entrepreneurial Skills and their Role in Enhancing the Relative Independence of Farmers: Results and Recommendations from the Research Project Developing Entrepreneurial Skills of Farmers, Frick, Switzerland. 
Schmidt, P., Bamberg, S., Davidov, E., Herrmann, J., Schwartz, S.H., 2007. Die Messung von Werten mit dem "Portraits Value Questionnaire". Zeitschrift für Sozialpsychologie $38,261-275$.

Schoon, B., Grotenhuis, R.t., 2000. Values of Farmers, Sustainability and Agricultural Policy. Journal of Agricultural and Environmental Ethics 12, 17-27.

Schwartz, S.H., 1992. Universals in the Content and Structure of Values: Theoretical Advances and Empirical Tests in 20 Countries. In: Zanna, M.P. (Ed.) Advances in Experimental Social Psychology, vol. 25. Academic Press, pp. 1-65.

Schwartz, S.H., 2003. A Proposal for Measuring Value Orientations across Nations, 259319.

Schwartz, S.H., 2005a. Human values: European Social Survey Education Net. http://essedunet.nsd.uib.no/cms/topics/1/. Accessed 3 March 2020.

Schwartz, S.H., 2005b. Robustness and fruitfulness of a theory of universals in individual values. In: Tamayo, A., Porto, J. (Eds.) Valores e trabalho. Editora Universidade de Brasilia, Brasilia, pp. 56-85.

Schwartz, S.H., 2012. An Overview of the Schwartz Theory of Basic Values. Psychology and Culture 2, 1-20.

Schwartz, S.H., Bilsky, W., 1987. Toward a universal psychological structure of human values. Journal of Personality and Social Psychology 53, 550-562.

Schwartz, S.H., Bilsky, W., 1990. Toward a theory of the universal content and structure of values: Extensions and cross-cultural replications. Journal of Personality and Social Psychology 58, 878-891.

Schwartz, S.H., Sagiv, L., 1995. Identifying Culture-Specifics in the Content and Structure of Values. Journal of Cross-Cultural Psychology 26, 92-116.

Teixeira, M.B., Vale, S.M.L.R.d., 2008. Estilos gerenciais e objetivos de agricultores da região norte do estado do Espírito Santo. (Farmers'management styles and objectives in the northern region of Espirito Santo, Brazil). Organizações Rurais \& Agroindustriais $10,226-238$. 
UBA (Umweltbundesamt), 2019. Erneuerbare-Energien-Gesetz.

https://www.umweltbundesamt.de/themen/klima-energie/erneuerbareenergien/erneuerbare-energien-gesetz\#erfolg.

van Praag, C.M., 1999. Some Classic Views on Entrepreneurship. De Economist 147, $311-$ 335.

Vesala, H.T., Vesala, K.M., 2010. Entrepreneurs and producers: Identities of Finnish farmers in 2001 and 2006. Journal of Rural Studies 26, 21-30.

Weltin, M., Zasada, I., Franke, C., Piorr, A., Raggi, M., Viaggi, D., 2017. Analysing behavioural differences of farm households: An example of income diversification strategies based on European farm survey data. Land Use Policy 62, 172-184.

Wiesinger, G., 2005. Landwirtschaft zwischen Tradition und Moderne - Über den Struktur und Wertewandel in der bäuerlichen Lebenswelt. Österreichische Gesellschaft für Agrarökonomie 10, 165-180.

Willock, J., Deary, I.J., McGregor, M.M., Sutherland, A., Edwards-Jones, G., Morgan, O., Dent, B., Grieve, R., Gibson, G., Austin, E., 1999. Farmers' Attitudes, Objectives, Behaviors, and Personality Traits: The Edinburgh Study of Decision Making on Farms. Journal of Vocational Behavior 54, 5-36.

Zhao, H., Seibert, S.E., Lumpkin, G.T., 2010. The relationship of personality to entrepreneurial intentions and performance: A meta-analytic review. Journal of Management $36,381-404$. 


\section{Appendix}

Table A-1: 21 items of the PVQ, male form (Baur et al., 2016)

\begin{tabular}{|c|c|c|c|}
\hline & Item & $\begin{array}{l}\text { First-order } \\
\text { value con- } \\
\text { structs }\end{array}$ & $\begin{array}{l}\text { Higher-order val- } \\
\text { ue constructs }\end{array}$ \\
\hline 1 & $\begin{array}{l}\text { Thinking up new ideas and being creative is important to him. } \\
\text { He likes to do things in his own original way. }\end{array}$ & Self-direction & Openness to change \\
\hline 2 & $\begin{array}{l}\text { It is important to him to be rich. He wants to have a lot of } \\
\text { money and expensive things. }\end{array}$ & Power & Self-enhancement \\
\hline 3 & $\begin{array}{l}\text { He thinks it is important that every person in the world should } \\
\text { be treated equally. He believes everyone should have equal } \\
\text { opportunities in life. }\end{array}$ & Universalism & Self-transcendence \\
\hline 4 & $\begin{array}{l}\text { It is important to him to show his abilities. He wants people to } \\
\text { admire what he does. }\end{array}$ & Achievement & Self-enhancement \\
\hline 5 & $\begin{array}{l}\text { It is important to him to live in secure surroundings. He avoids } \\
\text { anything that might endanger his safety. }\end{array}$ & Security & Conservation \\
\hline 6 & $\begin{array}{l}\text { He likes surprises and is always looking for new things to do. } \\
\text { He thinks it is important to do lots of different things in life. }\end{array}$ & Stimulation & Openness to change \\
\hline 7 & $\begin{array}{l}\text { He believes that people should do what they are told. He thinks } \\
\text { people should follow rules at all times, even when no-one is } \\
\text { watching. }\end{array}$ & Conformity & Conservation \\
\hline 8 & $\begin{array}{l}\text { It is important to him to listen to people who are different from } \\
\text { him. Even when he disagrees with them, he still wants to un- } \\
\text { derstand them. }\end{array}$ & Universalism & Self-transcendence \\
\hline 9 & $\begin{array}{l}\text { It is important to him to be humble and modest. He tries not to } \\
\text { draw attention to himself. }\end{array}$ & Tradition & Conservation \\
\hline 10 & $\begin{array}{l}\text { Having a good time is important to him. He likes to "spoil" } \\
\text { himself. }\end{array}$ & Hedonism & Openness to change \\
\hline 11 & $\begin{array}{l}\text { It is important to him to make his own decisions about what he } \\
\text { does. He likes to be free and not depend on others. }\end{array}$ & Self-direction & Openness to change \\
\hline 12 & $\begin{array}{l}\text { It is very important to him to help the people around him. He } \\
\text { wants to care for their well-being. }\end{array}$ & Benevolence & Self-transcendence \\
\hline 13 & $\begin{array}{l}\text { Being very successful is important to him. He hopes people } \\
\text { will recognize his achievements. }\end{array}$ & Achievement & Self-enhancement \\
\hline 14 & $\begin{array}{l}\text { It is important to him that the government ensures his safety } \\
\text { against all threats. He wants the state to be strong so it can } \\
\text { defend its citizens. }\end{array}$ & Security & Conservation \\
\hline 15 & $\begin{array}{l}\text { He looks for adventures and likes to take risks. He wants to } \\
\text { have an exciting life. }\end{array}$ & Stimulation & Openness to change \\
\hline 16 & $\begin{array}{l}\text { It is important to him always to behave properly. He wants to } \\
\text { avoid doing anything people would say is wrong. }\end{array}$ & Conformity & Conservation \\
\hline 17 & $\begin{array}{l}\text { It is important to him to get respect from others. He wants } \\
\text { people to do what he says. }\end{array}$ & Power & Self-transcendence \\
\hline 18 & $\begin{array}{l}\text { It is important to him to be loyal to his friends. He wants to } \\
\text { devote himself to people close to him. }\end{array}$ & Benevolence & Self-transcendence \\
\hline 19 & $\begin{array}{l}\text { He strongly believes that people should care for nature. Look- } \\
\text { ing after the environment is important to him. }\end{array}$ & Universalism & Self-transcendence \\
\hline 20 & $\begin{array}{l}\text { Tradition is important to him. He tries to follow the customs } \\
\text { handed down by his religion or his family. }\end{array}$ & Tradition & Conservation \\
\hline 21 & $\begin{array}{l}\text { He seeks every chance he can to have fun. It is important to } \\
\text { him to do things that give him pleasure. }\end{array}$ & Hedonism & Openness to change \\
\hline
\end{tabular}




\section{Summary and Conclusion}

Entrepreneurship in agriculture is becoming of greater importance with the changing framework conditions for agricultural production. This dissertation analyses the topic from different angles in order to gain a more comprehensive picture of the current situation and to provide politicians, stakeholders and farmers with fundamental insights and implications. Therefore, it consists of three contributions tackling three different research areas derived from the existing literature on agri-entrepreneurship research derived in the introduction. The first contribution identifies which different farmer types exist within a comprehensive sample of German farmers in order to generate a starting point and an orientation for agricultural policy design. The second one sets up the different strategic entrepreneurial choices existing in agriculture in general and aims at explaining which factors determine the choice of a certain strategy. Finally, the third contribution analyses the inner drivers of entrepreneurial action; farmers' values in order to get a deeper understanding of the underlying motives.

Ad 1: The results reveal that within the analysed sample of German farmers basically three clusters can be identified on the basis of quantitative personal and farm factors; conventional growers, versatile youngsters and family-based farmers. These farmer groups can be regarded as a result of past agricultural policy and need to be carefully considered for the planning of future policy in their individual ways. The conventional growers appear to be especially shaped by decades of encouragement of an efficient agricultural production, focussing mainly on rather conservative agricultural activities such as arable farming and refinement. Furthermore, they seem to be receptive for incentivised activities as can be concluded from high shares of production of renewable energy. Addressing this group, economic aspects should be centred. The versatile youngsters can be regarded as innovators among farmers; well educated with the highest shares of diversification activities. The versatile youngsters appear to be shaped by the recent developments of a call for multifunctional agriculture, still disposing over the highest amount of land. This group is of a high share involved in diversification activities turning market opportunities into a business. By doing so, they seem to be less dependent on policy decisions. They might represent a fertile target group for pushing forward innovations within the sector. Meanwhile the family-based farmers might be valuable actors in the context of maintaining vivid rural areas and the conservation of cultural landscapes. This group disposes over a high share of family support within the business while cultivating a rather small amount of land, many of 
them being involved in dairy farming. For them, any policies ensuring fair conditions to run the farm independently with the help of family workers appear to be acceptable.

Ad 2: Besides having this background of the different farmer types obtained from the cluster analysis, in the context of entrepreneurship the question arises which strategic entrepreneurial choices exist in general in agriculture and which factors determine these choices. In general it can be distinguished between reduction, continuation, expansion, diversification and the dual strategy of expansion and diversification. Each farmer can be uniquely assigned to one of these choice classes according to their implemented entrepreneurial activities following predetermined criteria. Analysing determinants, strong effects are observable within the area of personal factors. A high expression of creativity fosters diversification, also in combination with expansion. The more risk affine the farmer, the more likely they are to follow a dual strategy of expansion and diversification and the less likely they are to pursue a reduction strategy. Farmers holding a third-level qualification are significantly less likely to expand on existing activities and farmers with an off-farm job are more likely to reduce the business. In terms of farm factors, the greater the initial farm size, the less likely to choose a reduction, an expansion or a dual strategy of expansion and diversification. A central location of the farm lowers the probability to follow an expansion strategy. Within the area of context factors, only the involvement of the family, in particular of the spouse, has significant effects on the choice of an entrepreneurial strategy; the more family workers, the more likely they are to choose an expansion strategy. The involvement of the spouse increases the likelihood to choose a dual strategy. From these results it becomes visible that personal characteristics of the farmer and the family support are key for developing the farm business. To foster the self-awareness and understanding of agricultural entrepreneurs, concepts like risk and creativity should be taught early on in agricultural training programmes and continuously farmers should be encouraged and offered the opportunity to test and implement new concepts. This applies especially to smaller farms and farms with a central location in order to develop and implement alternative strategies to sustain themselves. Moreover, framework conditions should be created in such that many family members, particularly the spouse, have the opportunity to work in the business as this promises to have stabilising effects.

Ad 3: Digging deeper into the area of personal factors, the analysis of farmers' values reveals the underlying motivation for their entrepreneurial action. The results show that the farmers' value portrait is well compatible with the current challenges of a changed re- 
quirement profile. Farmers first and foremost prioritise self-transcendent values including aspects such as tolerance and protection for the welfare of people and nature, honesty, loyalty and responsibility. This matches with a lot of the new requirements. Second priority is set on openness to change consisting of self-direction implying aspects such as creativity, independence, freedom and curiosity, stimulation which describes a strive for novelty and challenges, and hedonism being characterised by pleasure, enjoying life and selfindulgence. Conservation, including tradition, security and conformity, is ranked third. This means that farmers are rather open to change than sticking to norms and traditions. The least importance is set on self-enhancement values including power and achievement. Analysing different value clusters among the sample and drawing conclusions on their entrepreneurial characteristics and activities, it becomes evident that the identified different value portraits do not correspond with existing conventional farm types, such as specialised dairy or arable farms. Still, the clusters differ significantly with regards to the involvement in structural diversification; the farmer clusters with distinct values of openness to change pursue more diverse business activities. At the same time these farmers are more risk affine. Thus, the uptake of activities beyond traditional farming activities implies a special value portrait. The farmer clusters with distinct conservation values show a higher percentage of part-time farming. The results reveal that the political goal of multifunctional agriculture is a concept which cannot be applied to all farmers to the same extent.

Overarching conclusions: Regarding the farmer, their central role in the context of entrepreneurship in agriculture is clearly pointed out in the results. To successfully sustain the changing framework conditions and to set up the farm for the future, farmers should in the first place make themselves aware of the different strategic entrepreneurial choices they have in general. They should then not only identify their current achievements but also their future goals. For doing so, they need to become aware of their personal inner value portrait to see what strategic choice best fits their inner motives. Furthermore it needs to be considered as well what fits their farm and, in case of a family farm, their family. In developing policy programmes, the different existing typologies of farmers should be taken into account. Farmers should be included in the development process of such programmes and be offered the freedom to choose the measures fitting to their preferences and profiles. Depending on the policy goal, it should be considered which factors determine what strategies and accordingly become aware of which measures lead to what results in order to prevent misallocation. A general conclusion for the sector as a whole is that in order to bring de- 
bates to a higher level, to understand each other better and to create more successful policy programmes, the inner motivations of the actors should be considered. According to the results at hand, the motivational drivers for an enhanced sustainable action are well-present within the farmers' value portrait. Furthermore, farmers of the present sample are open to change. In communicating and creating policy programmes, not monetary incentives should be put into the centre, but the sustainability and the benefit for the greater good, such as nature, society and farming families to become widely accepted and adopted.

Entrepreneurship is a topic of growing importance for the agricultural sector. This dissertation offers a starting point for further investigation. 


\section{Publication List}

\section{Articles published in scientific journals}

Graskemper, V., Yu, X., Feil, J.-H. (2021): Farmer typology and implications for policy design - An unsupervised machine learning approach. In: Land Use Policy 103, 105328.

Graskemper V., Yu X., Feil J.-H. (2021): Analyzing strategic entrepreneurial choices in agriculture - Empirical evidence from Germany. In: Agribusiness. 2021; 1-21.

Graskemper, V., Theuvsen, L. (2018): Entwicklung junger Führungskräfte für die afrikanische Landwirtschaft als Instrument nachhaltiger entwicklungspolitischer Zusammenarbeit. In: Berichte über Landwirtschaft - Zeitschrift für Agrarpolitik und Landwirtschaft. Band 96(2).

\section{Discussion papers}

Graskemper, V., Feil, J.-H. (2021): Values of Farmers - Evidence from Germany. In: Diskussionsbeitrag Nr. 2101 des Departments für Agrarökonomie und Rurale Entwicklung der Georg-August-Universität Göttingen, Februar 2021.

\section{Papers presented at major scientific conferences}

Graskemper, V., Feil, J.-H.: Values of Farmers as Guiding Principles for Action - Evidence from Germany. 65th Annual Australasian Agricultural and Resource Economics Society (AARES) Conference, February 8-12, 2021, in Sydney, Australia.

Graskemper, V., Meine, K., Feil, J.-H. (2020): Values of Farmers in the Context of Entrepreneurship - Evidence from Germany. 60. Jahrestagung der Gesellschaft für Wirtschafts- und Sozialwissenschaften des Landbaus e.V. (GEWISOLA), Herausforderungen für die ländliche Entwicklung - Wirtschafts- und sozialwissenschaftliche Perspektiven, IAMO, 23.-25. September in Halle (Saale).

Graskemper, V., Feil, J.-H. (2020): Determinants of Farmers' Strategic Entrepreneurial Choices - an Empirical Study in Germany. 64th Annual Australasian Agricultural and Resource Economics Society (AARES) Conference, February 10-14, 2020, in Perth, Australia. 
Graskemper, V., Feil, J.-H., Quiring, A. (2019): Unternehmertum und Entrepreneurship in der Landwirtschaft - eine empirische Untersuchung in Deutschland. 59. Jahrestagung der Gesellschaft für Wirtschafts- und Sozialwissenschaften des Landbaus e.V. (GEWISOLA), Landwirtschaft und ländliche Räume im gesellschaftlichen Wandel, Thünen-Institut, 25.-27. September in Braunschweig.

\section{Awards}

First Time Presenter's Award 64th Annual Australasian Agricultural and Resource Economics Society (AARES) Conference, February 10-14, 2020, in Perth, Australia. 